
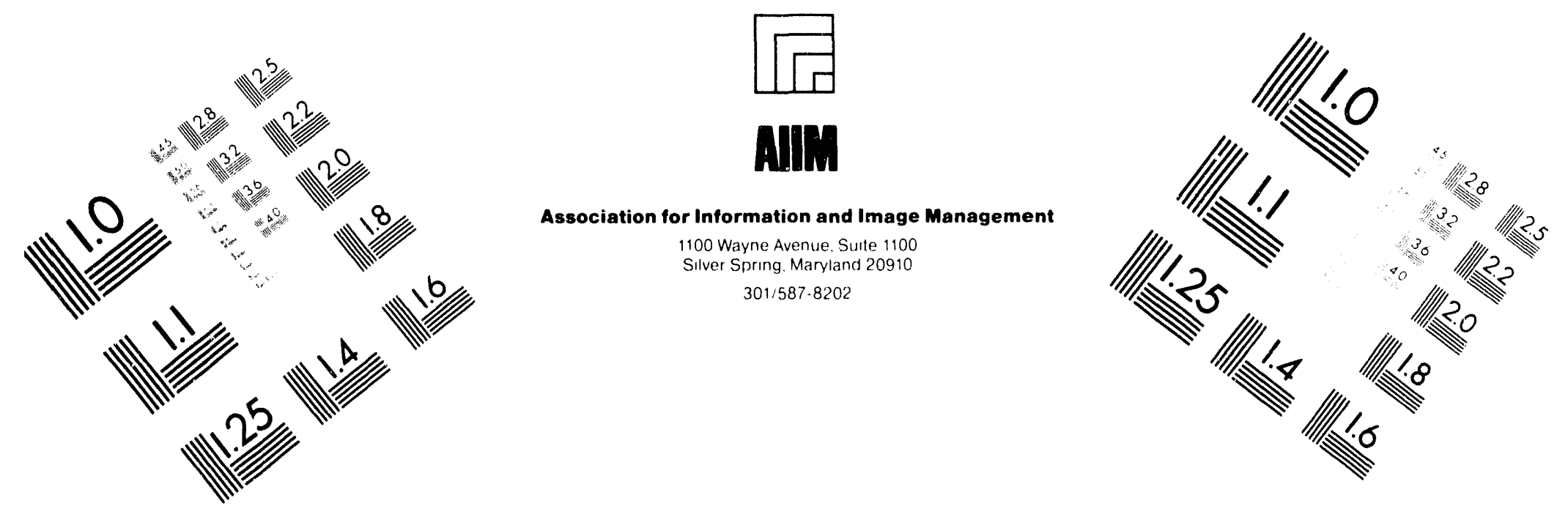

\title{
Centimeter
}

$\begin{array}{llllllllllllllll}1 & 2 & 3 & 4 & 5 & 6 & 7 & 8 & 9 & 10 & 11 & 12 & 13 & 14 & 15 & \mathrm{~mm}\end{array}$

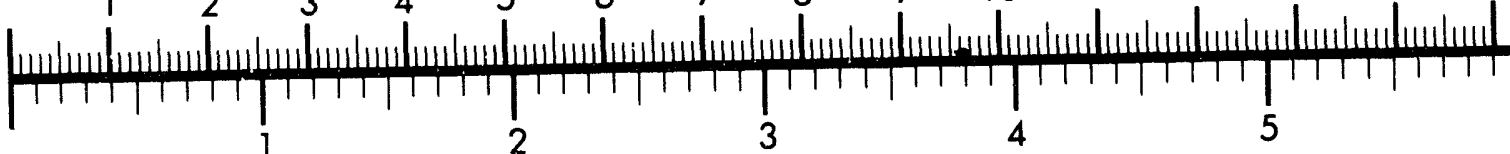
Inches
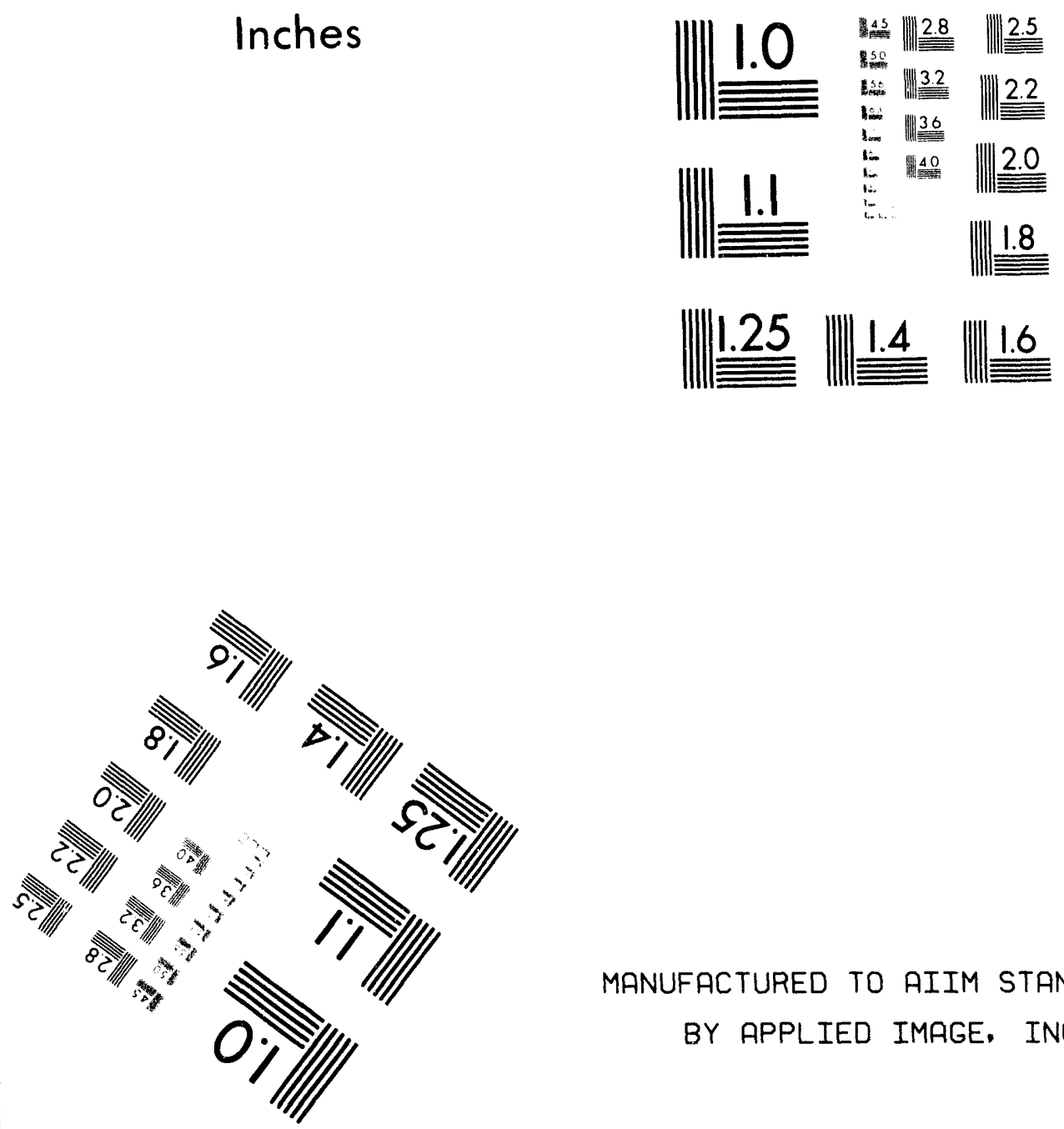

MANUFACTURED TO AIIM STANDARDS

BY APPLIED IMAGE, INC.

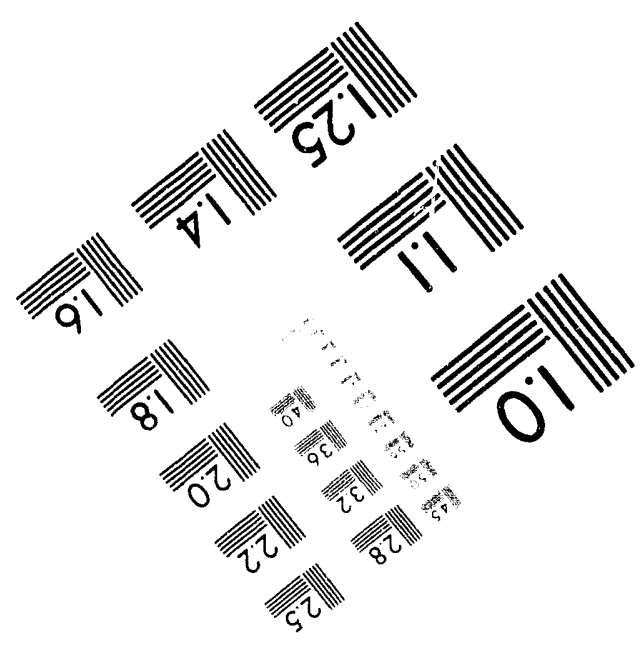



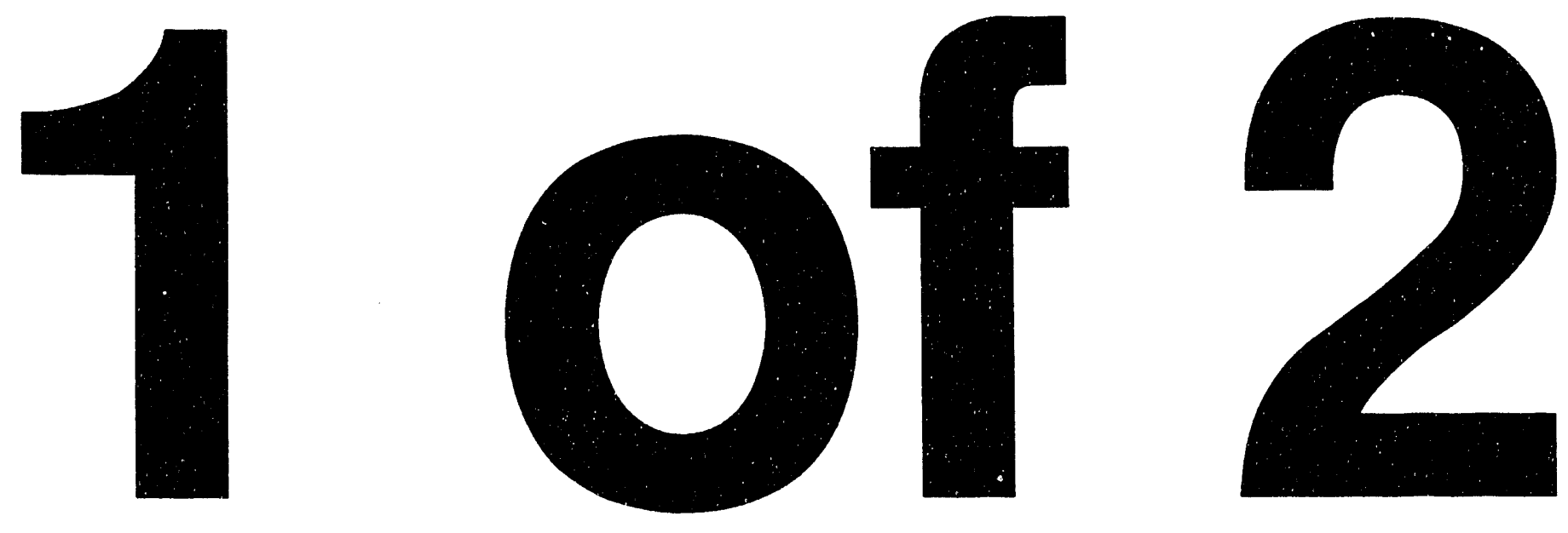


\section{Advances in Technology for the Construction of Deep-Underground Facilities}

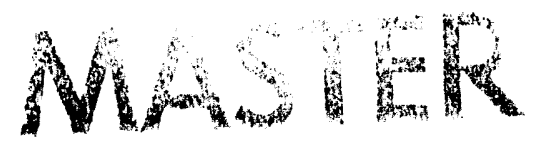

DIETRIGUTION OF THIS DOCUMENT IS UNLIMITES 


\title{
Advances in Technology for the Construction of Deep-Underground Facilities
}

\author{
Report of A Workshop \\ December 12-14, 1985 \\ conducted by the \\ U.S. National Committee on Tunneling Technology \\ and the \\ U.S. National Committee for Rock Mechanics \\ Commission on Engineering and Technical Systems \\ National Research Council
}

\section{DISCLAIMER}

This report was prepared as an account of work sponsored by an agency of the United States Government. Neither the United States Government nor any agency thereof, nor any of their employees, makes any warranty, express or implied, or assumes any legal liability or responsibility for the accuracy, completeness, or usefulness of any information, apparatus, product, or process disclosed, or represents that its use would not infringe privately owned rights. Reference herein to any specific commercial product, process, or service by trade name, trademark, manufacturer, or otherwise does not necessarily constitute or imply its endorsement, recommendation, or favoring by the United States Government or any agency thereof. The views and opinions of authors expressed herein do not necessarily state or reflect those of the United States Government or any agency thereof.

NATIONAL ACADEMY PRESS

Washington, D.C.

1987 
NOTICE: The project that is the subject of this report was approved by the Governing Board of the National Research Counc1l, whose members are drawn from the councils of the National Academy of Sciences, the National Academy of Engineering, and the Institute of Medicine. The participants in the workshop responsible for this report were chosen for their special competences and with regard for appropriate balance.

This report has been reviewed by a group other than the authors according to procedures approved by a Report Review Committee consisting of members of the National Academy of Sciences, the National Academy of Engineering, and the Institute of Medicine.

The National Academy of Sciences is a private, nonprofit, self-perpetuating society of distinguished scholars engaged in scientific and engineering research, dedicated to the furtherance of sclence and technology and to their use for the general welfare. Upon the authority of the charter granted to $1 t$ by the Congress in 1863, the Academy has a mandate that requires 1 t to advise the federal government on scientific and technical matters. Dr. Frank Press is pres1dent of the National Academy of Sclences.

The National Academy of Englneering was established 1n 1964, under the charter of the Nat1onal Academy of sciences, as a parallel organization of outstanding engineers. It is autonomous in 1ts administration and in the selection of 1 ts members, sharing with the National Academy of Sclences the responsibility for advising the federal government. The National Academy of Englneering also sponsors engineering programs almed at meeting national needs, encourages education and research, and recognizes the superior achlevements of englneers. Dr. Robert M. White 1 s president of the National Academy of Engineering.

The Institute of Medicine was established in 1970 by the National Academy of Sciences to secure the services of eminent members of the appropriate professions in the examination of policy matters pertaining to the health of the public. The Institute acts under the responsibillty given to the National Academy of Sclences by 1 ts congressional charter to be an adviser to the federal government and, upon 1ts own inlt1ative, to 1dentify 1ssues of medical care, research, and education. Dr. Samuel 0 . Thier is president of the Institute of Medicine.

The National Research Counc1l was organized by the National Academy of Sciences in 1916 to assoclate the broad community of science and technology with the Academy's purposes of furthering knowledge and advising the federal government. Functioning in accordance with general policles determinea by the Academy, the Council has become the principal operating agency of both the National Academy of Sclences and the National Academy of Engineering in providing seivices to the government, the public, and the scientific and engineering communities. The Council is administered jointly by both Academies and the Institute of Medicine. Dr. Frank Press and Dr. Robert M. White are chalrman and vice chalman, respectively, of the National Research Counc1l.

SPONSOR: This project was sponsored by the Defense Nuclear Agency through U.S. Bureau of Mines contracts Jol99025 and J0199030.

Coples of the report are avallable in limited supply from: The U.S. National Committee on Tunneling Technology, National Research Counc1l, 2101 Constitution Avenue NW, Washington, D.C. 20418. 


\section{PREFACE}

The workshop, "Advances in Technology for the Construction of Deep-Underground Facilities," was organized at the request of the Defense Nuclear Agency and conducted fointly by the U.S. National Committee on Tunneling Technology and the U.S. National Committee for Rock Mechanics in order to address technological 1ssues important to decisions regarding the feasibility of strategic options. The objectives of the workshop were to establish the current technological capabilities for deep-underground construction, to project those capabilitles through the compressed schedule proposed for construction, and to identify promising directions for timely allocation of existing research and development resources.

The earth has been used as a means of protection and safekeeping for many centuries. Recently, the thickness of the earth cover required for this purpose has been extended to the 2,000- to 3,000-ft range in structures contemplated for nuclear-waste disposal, energy storage, and strateglc systems. For defensive missile basing, it is now percelved that the magnitude of the threat has increased through better delivery systems, larger payloads, and vartable tactics of attack. Thus, depths of 3,000 to $8,000 \mathrm{ft}$ are being considered serlously for such facilities. Moreover, it appears desirable that the facilities be operational ( 1 not totally complete) for defensive purposes within a five-year construction schedule.

Deep excavations such as mines are similar in many respects to nearsurface tunnels and caverns for transit, rall, sewer, water, hydroelectric, and highway projects. But the differences that do exist are significant. Major distinctions between shallow and deep construction derive from the stress flelds and behavior of earth materlals around the openings. At shallow depths, a liner serves as a structural member that is capable of carrying the load of the overburden. As depth increases, a I1ner must be capable of redistributing the load to the surrounding rock, so that the rock and liner work in concert to provide a stable opening. Also, occurrences of spalling and stress slabbing are unusual in shallow construction but are increasingly prevalent with depth and must be accounted for in the design, excavation, and support processes. Different methodologies are required to accommodate other varlations resulting from 1ncreased depth, such as elevated temperatures, reduced capability for site exploration, and IImited access during project execution. This report addresses these and other questions in chapters devoted to geotechnical characterization, design, construction, and excavation equipment. 
Technical capability may be the prime 1ssue affecting the creation of deep-underground facllitles, but 1 t is not the only factor that need be consldered. A thread that wound through the deliberations for each chapter, and perhaps drew the most attention from the workshop participants, was a nontechnical concern. The success of an endeavor of such magnitude, and one involving a compressed construction schedule and engineering aspects on the cutting edge of technology, was seen to hinge ultimately on the question of contracting and management practices. The proposed project will require concerted interaction by a multidisciplinary team, but the structure of the contract and the attitude and organization of the management team must be flexible to allow such interaction. Current practice in the United states typlcally does not provide a sultably integrated framework that recognizes the special elements inherent in this type of project.

If the objective of constructing permanent underground facilities on a scale and at a depth that have not been attempted previously is to be achleved, it will be essential to utilize a site with good rock quality, proven rapid excavation methods, crews with a bent toward high productivity, and innovative contracting and management practices. Thus, as the potential threat to defensive facilities increases, it is advisable to establish the capability for construction at the pace and great depths now envisioned. The basic questions are whether it is possible and what technologles must be avallable in order for deep-underground facilities to be a viable strategic alternative. 


\section{U.S. NATIONAL COMMITTEE ON TUNNELING TECHNOLOGY 1985-1986}

\section{OFFICERS}

DONALD I. VIETH, Department of Energy, Cha1rman REUBEN SAMUELS, Thomas Crimmins Contracting Company, Vice Chairman Z.T. BIENIAWSKI, Pennsylvania State UnIversity, Immediate Past Cha1rman

\section{DESIGNATED REPRESENTATIVES}

PHILIP G. MEIKLE, U.S. Bureau of Mines, Federal Agencies GLEN R. TRAYLOR, Traylor Brothers, Inc., Associated General Contractors P.E. SPERRY, Tunnel Consultant, American Soclety of Civil Englneers JOHN W. WILSON, Advanced Mining and Construction, Inc., American Institute of Mining, Metallurgical, and Petroleum Engineers LLOYD B. UNDERWOOD, Consultant, Geological Soc1ety of America RONALD E. SMITH, Woodward-Clyde Consultants, Assoclation of Engineering Geologists

J. GAVIN WARNOCK, Acres Consulting Services, Ltd., Amerlcan Underground-Space Association HASSELI E. HUNTER, Consultant, Inst1tute of Shaft Dr1lling Technology

\section{INDUSTRY}

JED E. deMERS, Jr., Morrison-Knudsen Company, Inc. ANDREW F. DEMPSEY, Jr., Dempsey, Bast1anell1 \& Brown JAMES E. FRIANT, The Robbins Company VINTON A. GARBESI, Consultant HARVEY W. PARKER, Shannon and Wilson

\section{GOVERNMENT}

CHARLES A. BASKERVILLE, U.S. Geologlcal Survey ROBERT J. EVANS, U.S. Bureau of Mines MICHAEL A. GREENBERG, New York City Bureau of Water Supply JAMES H. MEINHOIZ, Milwaukee Metropolitan Sewerage District KENNETH D. SCHOEMAN, U.S. Bureau of Reclamation 
ACADEMIC AND RESEARCH ORGANIZATIONS

HERBERT H. EINSTEIN, Massachusetts Inst1tute of Technology

ALLEN W. HATHEWAY, University of Missour1 at Rolla

THOMAS D. O'ROURRE, Cornell University

LEVENT OZDEMIR, Colorado School of Mines

STANLEY L. PAUL, University of Illinols

RAYMOND L. STERLING, University of Minnesota

Staff

SUSAN V. HEISLER, Director

TERRIE NOBLE, Admin1strat1ve Assistant 


\section{U.S. NATIONAL COMMITTEE FOR ROCR MECHANICS}

1985-1986

\section{OFFICERS}

HOWARD J. PINCUS, UnIversity of WIscons1n--Milwaukee, Cha1rman and

Representative, American Society for Testing and Materials

DOUGLAS D. BOLSTAD, O.S. Bureau of Mines, Vice Chairman

JAMES H. COULSON, Tennessee Valley Authority, Immediate Past Cha1rman

\section{MEMBERS-AT-LARGE}

FRANCOIS E. HEUZE, Lawrence Iivermore National Iaboratory

THOMAS A. LANG, Consulting Engineer

DON A. LINGER, Defense Nuclear Agency

JAMES E. MONSEES, Metrora1l Transit Consultants

WILLIAM G. PARISEAU, OnIversity of Utah

CHRISTOPHER M. ST. JOHN, J.F.T. Agap1to and Associates

WOLFGANG R. WAWERSIK, Sand1a National Laboratories

MEMBER-REPRESENTATIVES OF SOCIETIES

DAVID F. FENSTER, Roy F. Weston, Inc., Association of Engineering Geologists EARL R. HOSKINS, Texas A\&M University, American Geophysical Union CHARLES H. DOWDING, Northwestern University, American Soc1ety of civil

Eng Ineers

SUNDER H. ADVANI, Ohio State University, American Soc1ety of Mechanical

Englneers

GEORGE A. RIERSCH, Geolog1c Consultant, Geological society of America

GARY R. OLHOEFT, O.S. Geological Survey, soc1ety of Exploration Geophysic1sts ROBERT G. LUNDQUIST, Ohlo State University, Society of Explosives Eng1neers VASUDEVAN RAJARAM, Englneers International, Inc., Soclety of Mining Engineers H. DONALD OUTMANS, Union Oil Company of California, Society of Petroleum Eng Ineers

C. WILLIAM LOVELL, Purdue Univers1ty, Transportation Research Board 
Staff

LYNNE F. CRAMER, D1 rector

VIRGINIA M. LYMAN, Administrative Assistant 
PARTICIPANTS IN THE WORKSHOP

CHAIRMAN

DONALD L. VIETH, U.S. Department of Energy

WORKING GROUP ON GEOTECHNICAL CHARACTERIZATION

DENNIS J. LACHEL, Lachel Hansen \& Assoc1ates, Inc., Chalrman MICHAEL J. BEUS, U.S. Bureau of Mines WILSON BLAKE, Consulting Mining Engineer

JAMES H. COULSON, Tennessee Valley Authority

FRANCOIS E. HEU2E, Lawrence IIvermore National Laboratory

HOWARD J. PINCOS, University of WIsconsin--Milwaukee

HOWARD R. PRATT, Sclence Applications International Corp.

MATT S. WALTON*, Minnesota Geological survey

WORRING GROUP ON DESIGN CONSIDERATIONS

WILIIAM G. PARISEAU, University of Utah, Chalrman Z.'I'. BIENIAWSKI, Pennsylva.a a State University DOUGLAS D. BOLSTAD, U.S. Bu ceau of Mines

DAVID G. HAMMOND*, Consultant

DANIEL E. HOKENS, U.S. Army Corps of Englneers, Omaha District

THOMAS A. LANG*, Consultant

DOUGAI R. MCCREATH, Golder Assoclates, Inc.

WORKING GROUP ON CONSTRUCTION ISSUES

EDWARD J. CORDING, Oniversity of Illino1s, Cha1rman

FRED W. BRACREBUSH, Hecla Mining Company

THOMAS R. KUESEL, Parsons Brinckerhoff Quade \& Douglas, Inc.

JOHN R. MARKS, JR, Homestake Mining Company

JAMES S. REDPATH, J.S. Redpath, Ltd.

REUBEN SAMUELS, Thomas Crimmins contracting Co.

MICHAEL SORASKI, U.S. Bureau of Mines

FRANK J. SOLAEGUI, Reynolds Electric \& Englneering Co. 
WORKING GROUP ON EXCAVATION EQUIPMENT AND SYSTEMS

PRISCILLA P. NELSON, University of Texas at Austin, Cha1rman JAMES E. FRIANT, The Robbins Company

TONY J. PEACH, Boretec, Inc.

ELDRED O. MIXON, Renny Construction Co.

PATRICR D. LINDSEY, U.S. Army Corps of Engineers, Omaha District

RUSSELL J. MILLER, Colorado School of Mines

CARL H. SCHMUCK, Homestake Mining Co.

P.E. SPERRY, Tunnel Consultant

*Unable to attend workshop 


\section{CONTENTS}

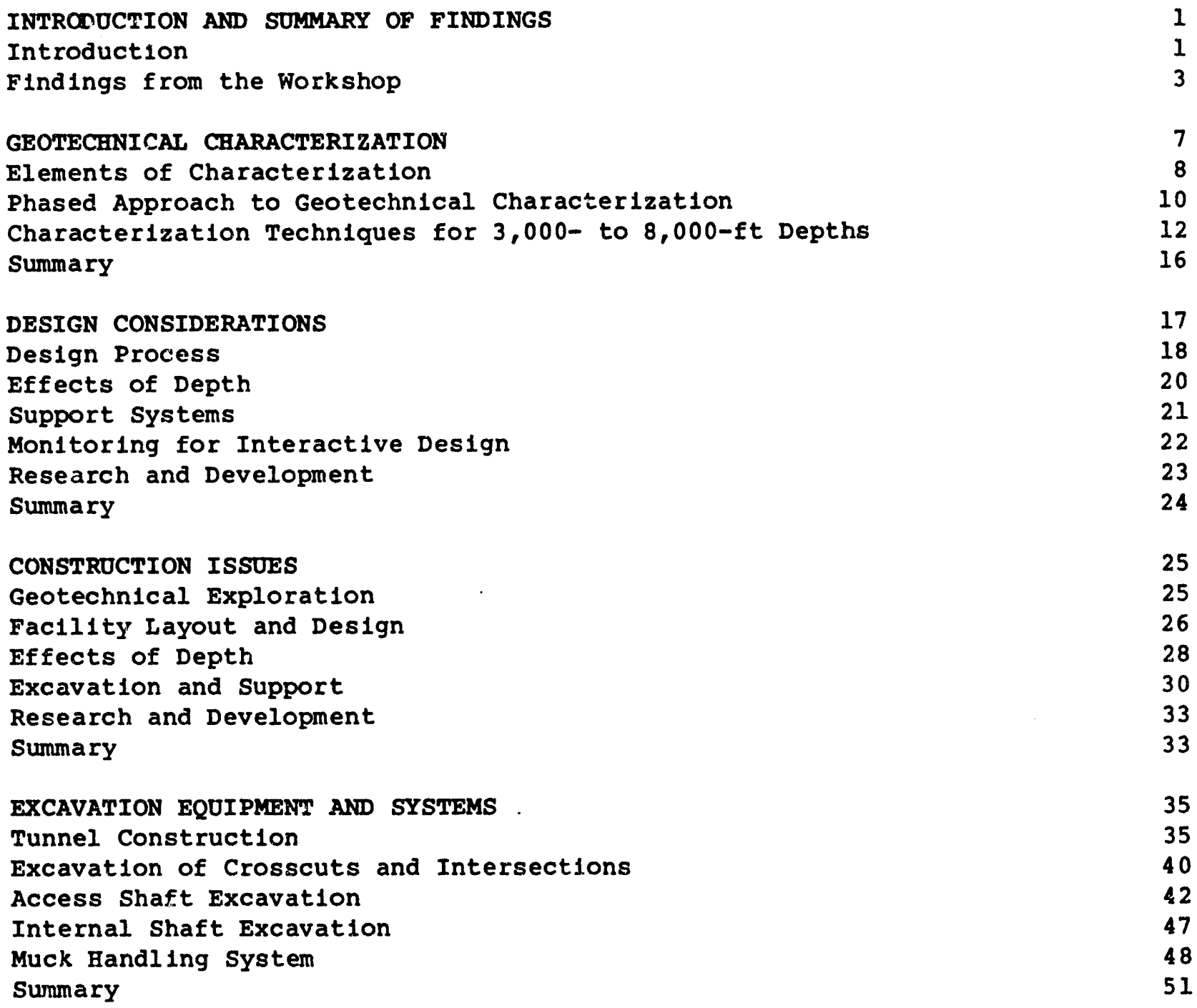




\section{INTRODUCTION AND SUMMARY OF FINDINGS}

\section{INTRODOCTION}

As one ineans of determining the feasibility of current and developing concepts for deep strategic facilities, the Defense Nuclear Agency requested that the D.S. National Committee on Tunneling Technology (USNC/TT) and the U.S. National Committee for Rock Mechanics (USNC/RM) organize a workshop to assess advances in technologies and practices related to the construction process. The scope of the workshop was intended to complement a similar activity conducted in 1981 by the U.S. National Committee on Tunneling Technology. The resulting report (1982), Design and Construction of Deep-Underground Basing Fac1lities for Strategic Missiles, which concentrated on the general technical and management issues raised by the basing option envisioned at that time, served as a significant resource for deliberations at this workshop. Two other docuinents previously prepared by the committees (USNC/RM, 1981; USNC/TT, 1984) also provided reference material.

The primary difference between the basing concepts considered in the two workshops is the specification of facllity depth. The first concepts were 2roposed at depths that are relatively shallow $(2,500$ to $3,000 \mathrm{ft})$ in comparison with current proposals of depths up to $8,000 \mathrm{ft}$. To address the concept of facilities at the depths now contemplated, the workshop was designed to draw on experience developed in underground civil engineering projects and in the construction and operation of deep mines. The mining perspective contributed valuable insights regarding actual workings at the depths of interest.

U.S. National Committee on Tunneling Technology. 1982. Design and Construction of Deep-Underground Basing Facilities for strateg1c Miss1les (Volume l, Evaluation of Technical Issues; Volume 2, Briefings on system Concepts and Requirements). Washington, D.C.: National Academy Press.

U.S. National Committee for Rock Mechan1cs. 1981. Rock-Mechanics Research Reguirements for Resource Recovery, Construction, and Earthquake-Hazard Reduction. Washington, D.C.: National Academy Press.

U.S. National Committee on Tunneling Technology. 1984. Geotechnical site Investigations for Underground Profects (Volume 1, Overview of Practice and Legal Issues, Evaluation of Cases, Conclusions and Recommendations; Volume 2, Abstracts of Case Histories and Computer-Based Data Management system). Washington, D.C.: National Academy Press. 
The participants were selected to represent a varlety of expert1ses as well as practical and theoretical viewpolnts. The combination of backgrounds and knowledge--ranging from academicians concerned with basic research to geotechnical engineers to designers and contractors for tunnels and shafts to specialists in mine ventilation--and the resulting $\mathrm{mix}$ of opinions were essential in assessing the technologies and practices applicable to the basing concept.

\section{Assumptions}

To allow evaluation of technical issues without constraint, the workshop was not restricted to examination of particular systems or schemes for deepunderground facilities. Specifications and requirements were indicated only in broad terms. However, it was necessary to develop some assumptions regarding the geology, extent and lifetime of the facilities, and schedule and means of excavation. Specifically, the assumptions presented to the participants included the following:

- The excavation will consist of a complex network of lined and unlined, short and long shafts, chambers, and tunnels with flat and inclined grades, as well as junctions of various configurations.

- Long-term (50 to 100 years) stab1lity of the openings is essential.

- The construction schedule will be compressed (five years to operable status).

- Excavation will be primarily by mechanical means (1.e., with minimal blasting).

- The range of opening diameter under consideration is $6 \mathrm{ft}$ to $25 \mathrm{ft}$.

- The range of tunnel length under consideration is from less than

$1,000 \mathrm{ft}$ up to $20 \mathrm{miles}$.

- Depths of construction may reach $8,000 \mathrm{ft}$.

- Geothermal gradient averages $10^{\circ} \mathrm{F}$ per 1,000 ft of depth but may be substantially greater.

- Groundwater flows may be encountered.

- Vertical stress increases with depth and horizontal stress varies from less than up to several times the vertical stress.

- The range of rock strength (unconfined compression) 1ncludes: soft (1ess than $10,000 \mathrm{ps} 1)$, medium $(10,000$ to 20,000 ps1), hard $(20,000$ to 30,000 psi), and very hard (greater than 30,000 psi).

This set of general assumptions served as the basic framework for discussions at the workshop.

\section{Structure of the Workshop}

To focus the workshop, the question of building facilities at great depth was divided into four main components:

- The ability to gather geotechnical information for site selection, design; and construction.

- The ability to specify the configuration of the opening(s) and the nature of the support system. 

- The ability to create the opening(s) safely and efficlently.
- The capability of the equipment necessary for mining and rock handling.

To address these areas, four working groups were created. The concepts and basic framework for the working groups were structured in the following manner.

Geotechnical characterization focused on the process of collecting the information necessary to understand the earth's structure and conditions for designing and building the facility, an effort that could require the evaluation of a volume of 15 cublc miles of rock. The outstanding questions centered around the information needed to select a site that has the proper characteristics, a strategy for evaluating an enormous volume of rock in a reasonable time frame, and the technologies required to obtain the information.

Design focused on the processes of specifying the configuration of the facility within the context of the natural rock that must serve as the eng1neering material. The outstanding questions centered around analysis of the reaction of the rock to the creation of openings, and the specification of the support system necessary to ensure that the openings are stable under the high stresses and time-dependent behavior likely to be encountered.

Construction focused on issues affecting the ability to mine and support the openings in a safe and efficient manner. The outstanding questions centered around the geotechnical conditions that would affect the excavation method and sequence, means to limit risk to health and safety of personnel, and the influence of facility layout on construction performance.

Excavation equipment focused on the tools necessary to support rock breaking, opening stabilization, and muck removal. The major questions centered on current and potential mechanical systems that can perform rapidly and reliably for differing distances and configurations, and constraints on operability that may be amenable to modification in the near term or to application of emerging technologies.

The scope of the working groups was intentionally limited to technical concerns. The political, environmental, and strategic issues surrounding the concept of deep facilities for defensive purposes were explicitly avolded. Other topics deemed inappropriate for specific consideration included nuclear weapons effects, survivability, retallatory capability, and egress.

\section{FINDINGS FROM THE WORKSHOP}

\section{Summaries of the Working Groups}

Geotechnical characterization plays a key role in all stages of the development of deep-underground facilities, from initial reconnalssance and site selection through post-construction activities. A phased, observational approach is essential in view of the volume of rock involved and remoteness 1mposed by 1 ts depth, as well as the time constraints of the schedule. Many of the currently avallable characterization techniques are applicable to the proposed project. However, the ability to evaluate factors that pose special problems for deepunderground profects will require improvements in exploration, testing, and instrumentation technologies. These improvements include development of instruments which work longer under adverse environmental conditions, new technologies for evaluating in-situ stress, and methodology to determine remote 
fracture systems in 3-D. Equally important is the use of enlightened contracting practices which permit exploration, design, and construction to be integrated into a unified, contemporaneous effort.

Design of stable openings at the depths of interest requires increasing attention to design principles. The technology is not synonymous with the more common, civil construction at relatively shallow depths. Quantitative knowledge of rock mass and support behavior becomes more 1mportant, and reliance at least in part on the natural support provided by the rock becomes essential. Interactive design, accompanied by instrumentation and monitoring of the rock/ support system, 1s critical for design validation. Developments that would be beneficial include nonborehole geophysical systems for use at the face, computer programs for analysis of folnted rock-mass and support response under large displacements, and capabilities for integration of yleldable elements into the support system. The design process will demand close ties with geotechnical characterization and construction activities, and the contractual format must be carefully considered to provide for efficlent implementation of design.

Construction procedures, performance, and schedule are determined essentially by geotechnical coilditions at the site and by layout and design of the facility. Each may 1mpose significant positive or negative consequences that Influence construction requirements, efficlency, economy, and safety. Specific concerns that must be addressed in complex operations at depth are temperature and ventilation, in situ stress, groundwater inflow, rock quality, and logistics. Several areas where technological developments can enhance constructibility include boring machine performance in violently spaling ground, efficient installation of support systems with large displacement capabilities, and directional control of raise-drilling pilot holes. A crucial requirement for effective construction will be contracting and management practices that provide flexibility for changes as excavation proceeds.

Excavation equipment and systems currently offer the basic technological capabilities for construction of deep facilities. The geotechnical environment and profect layout are 1mportant factors in system component selection and function. Full-face boring is the preferred means for efficient tunnel excavation, combined w1th "no-delay" systems for haulage and support installation. For access shafts, b? Ind boring is potentlally the fastest, lowest cost method. For internal shafts, excavation by enlargement of directionally drilled pilot holes is the optimum method. Machine modifications and application of emerging technologies may be expected to contribute substantially to equipment performance.

\section{Contracting and Management Issues}

Historlcally, site characterization, facility design, and project construction have been considered separate and distinct entities. For conventional underground structures, this view has been accentuated in recent years by improved abilities to characterize and evaluate the site, to design openings consistent with the natural conditions, to develop improved materials for construction, and to create stable openings. However, as demands increase for unconventional, deeper structlires, the paucity of knowledge and understanding of the site and of the magnitude and degree of variation in rock properties w1ll not allow independence of geotechnical characterization, design, and construction. For a project that challenges technology, it is essential to establish a firm 
basis for teamwork involving the investigators determining the variations in the site, the designer specifying the fit of the structure to the rock, and the constructors excavating and stabllizing the openings. Consequently, contractIng and management philosophles must be orlented to permit, or perhaps demand, adoption of means to ensure close coupling of these activities.

Effective approaches to contracting and management will not only acknowledge the special elements of a profect but also provide for equitable sharing of risks, establish cl ar procedures for timely resolution of design and construction changes as encountered, and foster communications and morale essential to productivity and teamwork (USNC/TT, 1978). In the United States, general practice is to use competitively bid, fixed-price contracts for underground construction. However, a single type of contract cannot sult all clrcumstances and in sore instances is most inappropriate. A prime example of the latter case is a profect where the schedule is critical and it is essential to begin construction well before final designs are finished and the plans and speciflcations completed (USNC/TT, 1974)--a case not unlike the project considered in this report.

In a suitable situation, a fixed-price contract can offer the owner a presumably firm price for the work and motivate the contractor to achleve the lowest possible cost. However, the inherent disadvantages can serlously undermine the ability to obtain a project that is on schedule, within budget (or at reasonable cost), and operates to design. Considerations in the use of fixed-price contracts include the following:

- For competitive bidding, the work must be specifled in great detall. Yet, as the work proceeds, the detalls may be revised to accommodate conditions actually encountered. Thus, a solid basis for preparing a bid rarely exists.

- The contractor 1s often required to accept extensive risks related to unknown subsurface conditions. The bid reflects this risk in the form of a substantial contingency, and the progress of the work determines whether the contractor or owner benefits. The result is higher initial costs and an adversarial relationship that promotes expensive and timeconsuming disputes and litigation.

- Changes during construction--a common occurrence for underground projects--are often expensive and involve readily contested issues of necessity and financial responsibility. When the price for the work is fixed, owners and contractors are forced to adopt rigid, defensive positions that not only can affect construction performance but also lead to costly schedule delays, disputes, and litigation.

- Inflexibility in contracting discourages the use of innovative design and construction techniques and improved technologies, thereby resulting in unnecessarily high costs for construction.

U.S. National Committee on Tunneling Technology (1978). Better Management of Major Underground Construction Projects. Washington, D.C.: National Academy Press.

U.S. National Committee on Tunneling Technology (1974). Better Contracting for Underground Construction. Washington, D.C.: National Academy Press. 
A sultable contracting and management framework will acknowledge the special elements of the proposed project and the constraints 1mposed by great depth, long tunnel lengths, and compressed schedule. Ne1ther time nor resources will permit securing preconstruction geotechnical information suff1clent to define the work for flxed-price bidding. In general, maximum economy and minimum disputes will result if the contract documents include risk-sharing provisions, anticlpate and provide means for resolving the types of construction problems that may be encountered, and permit contractor compensation in the manner that costs are incurred. Such a system is commonly used overseas, although it is relatively novel for U.S. projects. In Canada, however, a simllar system was used successfully for the Rogers Pass tunnel, where the constraints resemble the proposed profect. Another means to minimize bid contingencies and disputes and delays during construction is appointment of a D1sputes Review Board prior to construction. Such boards have be $n$ successfully engaged for the Eisenhower and Mt. Baker Ridge tunnels in the United States.

\section{Conclusion}

The consensus of the working groups is that the basic technical capabilities to create complex underground facilities at the pace and depths envisioned are avallable in current practice. The necessary 1mprovements and advances in technology hold reasonable potentlal for development within a short to moderate period of time. Therefore, efforts to initlate a deep-underground facility could be undertaken while the technical developments are being pursued. For major clvil projects, a confident approach often signals the demand that naturally attracts technological achlevements.

The consensus also is that the issues and limitations to be resolved are varied, often intricate, and sometimes formidable. Although the technical basis continues to expand, the practice of designing and constructing an underground facility is still less a sclence than an art. The accent on art lies in assembling components of exact specifications and known response into a set configuration within a basic engineering material for which neither the characteristics nor behavior can be determined with precision. The concept of extensive, deep-underground facilities tests the farthest reaches of technology and art, as well as the mettle of the parties involved throughout the design and construction processes. However, the path from concept to completion does not appear to present insurmountable obstacles.

The challenges in creating deep-underground facilities are not solely technical in nature. An integral part of the endeavor, and an 1ssue that is fundamental to success, is the philosophy practiced in contracting and managing the profect. The structure of the contract and the organization of the management team will have to be both flexible and highly integrated. Each will have to be implemented in a manner that recognizes the essential interdependence of geotechnical characterization, design, and construction. 


\section{GEOTECHNICAL CHARACTERIZATION}

Geotechnical characterization for deep-underground facilities (1.e., depths of 3,000 to $8,000 \mathrm{ft}$ ) constitutes a $\mathrm{mix}$ of old, new, and emerging technologies. Most of the currently avallable characterization techniques are applicable to the data requirements of the proposed program. However, there is a need to Improve certain technologies and a critical requirement to identify specific features as early in the exploration program as possible. The volume of rock is enormous and remote, the potential for conditions particularly adverse to design and construction is significant, and the schedule for the profect is compressed.

These considerations cannot be accommodated properly within the structure commonly adopted for a geotechnical program. Typically, the exploration phase is completed prior to design and detailed characterization is completed prior to construction. For a deep-underground facility, this approach is not a prerequisite of initiating either design or construction.

The recommended geotechnical program includes the use of an 1terative approach that analyzes the exploration data as they are produced and prior to implementing the next step in exploration. In this manner, "fatal flaws" are identifled early and a site abandoned before any additional funds are used for characterization. Further, this 1terative approach is also intended to be interactive: explorations are conducted in cooperation with the designers and constructors and continue through the design and construction processes.

The iterative/interactive approach assumes a multidisciplinary team of englneers, geologists, and contractors experienced in deep-underground projects. This geotechnical design team should be supplemented by an independent peer review group which meets on a regularly scheduled basis from project inception through completion of construction. Geotechnical characterization must be an integral part of the entire profect.

Many of the philosophical concerns applicable to a geotechnical program for deep-underground construction are presented in a recent case-history study of underground profects (USNC/TT, 1984). That study also addresses some of the supportive contracting and management philosophies that permit the exploration e.fort to contribute effectively to all project phases.

\footnotetext{
U.S. National Committee on Tunneling Technology. 1984. Geotechnical site Investigations for Underground Projects. Washington, D.C.: National Academy Press.
} 
The program of exploration is intended to generate geotechnical data from the Initial reconnalssance through pcst-construction phases of the project. The effort to characterize a site requires the continuous development and analysis of Information on a variety of factors which, e1ther separately or in differing combinations, may affect several aspects of the project. Thus, 1 t is essential that detalled exploration continue concurrently with design and construction.

Facilities at the depths envisioned involve a significant potential to encounter elevated ground temperatures, adverse lithology and structure, high in-situ stresses, and high-pressure inflows of water. Another concern, ground shock attenuation, is critical to strategic facilities at these depths. These factors are considered most important because substantial occurrences could preclude reasonable construction or operation. For example, extensive shear zones, very soft rock, and excessive stresses would prevent safe construction.

The elements of characterization and their applicability to design, construction, excavation equipment, and static and dynamic loading are indicated in the matrix shown as Table 1. The significant elements for each category are noted by an " $x$ " in the approprlate column. Sequence or other time-dependence is not implied by relative position in the matrix. For example, temperature data may be used for design purposes before, during, or after the same or other temperature data are used for some phase of construction.

Each of the "Critical Geotechnical Parameters" is considered to be critical because of the potential to establish a "fatal flaw": that 1s, a single parameter may be sufficiently unfavorable for design, construction, or performance to disqualify a candidate site. Under some circumstances, a factor such as very low unconfined strength may serve the same purpose.

"Design" clearly relies extensively on the range of characterization elements. As might be expected, the close relationsh1p between "Construction" and "Equipment" is reflected by a similarity in applicable elements. The remaining columns call attention to the characterization parameters required to address the abllity of the host rock to support and transfer loads.

\section{Influence of Characterization}

The Influence of characterization on individual aspects of a profect is extended by the interaction between these aspects. For example, Table 2 summarizes the manner in which geotechnical elements and facility layout affect equipment for excavation and support installation. In this case, characterization is significant not only directly but also indirectly via the relationsh1p between facility layout and equipment.

Geotechnical parameters are of central 1mportance in system component selection and function. For example, a full-face tunnel boring machine (TBM) designed for optimum performance in soft rock is not capable of efficiently cutting hard rock unless modifled (e.g., larger diameter cutters, increased hydraulic-thrust pressure) The potential for encountering substantive changes in rock conditions must be anticipated so that the machine design can incorporate the specific features that allow such modifications. A particular concern overall is the possible presence of poor-quality rock of sufficlent extent to interfere with mining, as well as excessive water inflows and gas.

Equally important to equipment selection is the project layout, which is itself subject to the characterization process. The geotechnical environment 
CRITICAL GEOTECHNICAL

PARAMETERS

Temperature (rock mass)

$\mathbf{x}$

$\mathbf{x}$

$\mathrm{x}$

Shock attenuation

(rock mass)

$\mathrm{x}$

$\mathrm{x}$

Structire (including

discontinuities)

Strat1graphy

In-situ stress

Hydrology

Other liquids and gas

\section{$\mathrm{x}$}

$x$

$x$

$\mathrm{x}$

$\mathrm{x}$

PHYSICAL PROPERTIES/BEHAVIOR

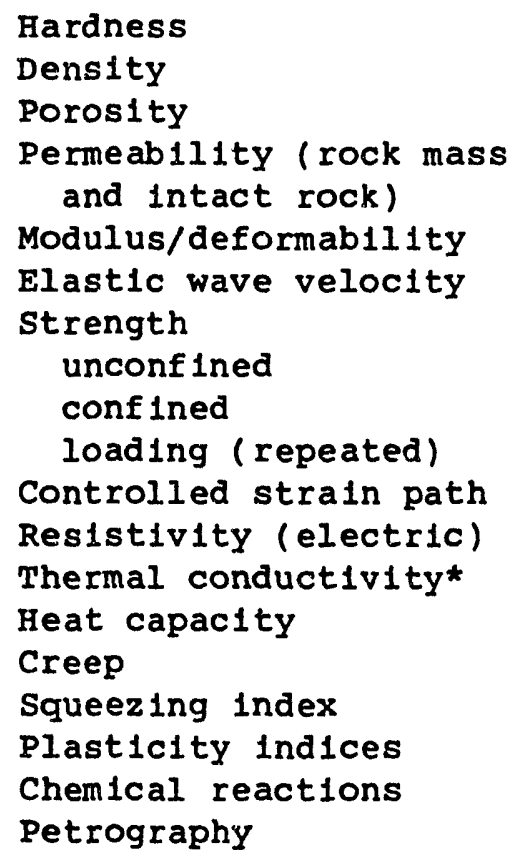

$\mathrm{x}$

$\mathrm{X}$

$\mathrm{X}$
$\mathrm{x}$
$\mathrm{X}$
$\mathrm{X}$
$\mathrm{x}$

$\mathrm{X}$
$\mathrm{X}$
$\mathrm{X}$
$\mathrm{X}$
$\mathrm{X}$

$\mathrm{x}$

$\mathrm{x}$ $x$ $\mathrm{X}$ $\mathrm{X}$

$\mathrm{x} \quad \mathrm{x}$ $\mathrm{x}$

*Also thermal diffusivity. 
1s a critical factor in determining the stability of openings and the appropriate configuration for tunnels, caverns, and shafts. In like manner, the geotechnical environment must be careiully considered in the plans for inclines and declines, which may present requirements vastly different than tunne is or caverns. All of these layouts influence selection of equipment, which may in turn restrict grades and turning radi1. The interactive nature of design an construction is clearly exemplifled here.

TABLE 2 Influence of Characterization and Layout on Selection of Equipment for Excavation and Prlmary Support

\begin{tabular}{|c|c|c|c|c|c|c|c|c|}
\hline & \multicolumn{4}{|c|}{ Geotechnical Elements } & \multicolumn{4}{|c|}{ Layout } \\
\hline & $\begin{array}{c}\text { Intact } \\
\text { Rock } \\
\text { Strength } \\
\end{array}$ & 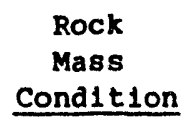 & $\begin{array}{r}\text { Over- } \\
\text { stress } \\
\text { Fallure } \\
\end{array}$ & Water & Depth & Decline* & Incline* & Curves \\
\hline Bor Ing Equ1pment & $\mathbf{M}$ & $\mathbf{M}$ & I & m & m & $\Pi$ & $\mathbf{M}$ & m \\
\hline Cutting Tools & $\mathbf{M}$ & I & 0 & $\mathbf{m}$ & 0 & I & 0 & $\mathbf{M}$ \\
\hline \multicolumn{9}{|l|}{ Muck Transport } \\
\hline At heading & m & m & 0 & $\mathbf{M}$ & 0 & $\mathbf{M}$ & $\mathbf{m}$ & m \\
\hline $\begin{array}{l}\text { Forlzontal } \\
\text { haulage }\end{array}$ & m & $\mathrm{m}$ & 0 & $\mathbf{M}$ & 0 & $\mathbf{M}$ & $\mathbf{m}$ & $\mathbf{M}$ \\
\hline $\begin{array}{l}\text { Vertical } \\
\text { haulage }\end{array}$ & m & $\mathbf{M}$ & 0 & $\mathbf{M}$ & $\mathbf{M}$ & $\mathbf{M}$ & $\mathbf{M}$ & $\mathbf{M}$ \\
\hline Primary Support & m & $\mathbf{M}$ & $\mathbf{M}$ & $\mathbf{M}$ & $\mathbf{M}$ & m & m & $\mathrm{m}$ \\
\hline $\begin{array}{l}\text { Assumed greater } \\
\text { Legend: M (major } \\
\text { I (inter } \\
\text { m (minor } \\
0 \text { (no ir }\end{array}$ & $\begin{array}{l}\text { than } 15 \text { pe } \\
\text { ) strong } \\
\text { mediate) } \\
\text { ) = some } \\
\text { fluence) }\end{array}$ & $\begin{array}{l}\text { rcent. } \\
\text { Impact on } \\
\text { slgnifican } \\
\text { onsideratic } \\
\text { little 1mp }\end{array}$ & $\begin{array}{l}\text { system co } \\
\text { it 1mpact } \\
\text { on should } \\
\text { pact on eq }\end{array}$ & $\begin{array}{l}\text { mponent } \\
\text { but not } \\
\text { be give } \\
\text { gulpment }\end{array}$ & $\begin{array}{l}\text { select } \\
\text { an ove } \\
\text { for ec } \\
\text { select }\end{array}$ & $\begin{array}{l}\text { on and fun } \\
\text { riding inf } \\
\text { ulpment se } \\
\text { on. }\end{array}$ & $\begin{array}{l}\text { ction. } \\
\text { luence. } \\
\text { lection. }\end{array}$ & \\
\hline
\end{tabular}

PHASED APPROACH TO GEOTECHNICAL CHARACTERIZATION

The magnitude of the proposed project and the compressed schedule dictate that special care be taken to integrate exploration, design, and construction into a unffled, contemporaneous effort. The volume of rock involved and remoteness imposed by 1 ts depth, as well as time constraints, eliminate the possibility of obtaining data sufficlent to provide sultable knowledge of the underground prior to construction. Therefore, a phased observational approach is essent1al. This approach to the geotechnical effort will allow ldentification of a location with enough certainty to inftiate the project, while the detalls required for final design and effective construction are determined according to information obtained at depth as construction proceeds.

It is assumed that an inftial screening process to identify approximately 25 potential sites, each about 10 square miles in plan, w1ll precede the program for geotechnical characterization. The program would then involve four 
broad phases: site selection, site characterization, construction, and postconstruction.

\section{Phase I Site Selection}

Preliminary site selection 1s intended to reduce the number of possible sites from approximately 25 to 3 candidates that are geotechnically most promising. At this stage, lack of physical access to the 25 sites 1 s an imposed constraint. Therefore, all avallable sources of existing information must be carefully examined--e.g., mines, boreholes and logs, geologic and topographic mapping, state and federal geologic survey data, o1l and gas drilling data. These sources should be supplemented, if necessary, by techniques such as remote sensing with systematic analysis. The critical factors to evaluate include J1thology, geologic structure, temperature gradient, in-situ stress, shock attenuation characteristics, hydrology, and existence of hazardous gas. The systematic evaluation of potential sites will allow the selection of three candidate sites, as well as the proposed depth of installation for each site and the possible locations for access openings.

The next stage in the site selection process involves field exploration efforts at each of the three candidate sites. Field work should progress immediately with detalled surface mapping, hydrologic studies, and one hole drilled to at least $500 \mathrm{ft}$ below the proposed maximum depth of installation at each site. Complete suites of tests on the core and in the holes should be performed to establish values for all pertinent design and construction parameters. Additional boreholes should be planned carefully, with the spacing and location of each hole chosen to satisfy individual conditions at each site. It is anticlpated that a minimum of 5 holes per 10 square miles of surface area will be required during the selection process. The testing program should also include experiments designed to estimate characteristics of shock attenuation. Both mathematical simulation and fleld testing with high explosives should be considered for this purpose.

A detalled geotechnical report of the three candidate sites should be prepared. Th1s report, coupled with preliminary design, construction, and operation schemes, w1ll allow selection of a single site for construction.

\section{Phase II S1te Characterization}

In1tially, detalled site characterization should be accomplished primarily with exploration shafts and tunnels. It is important that these shafts and tunnels be located to maximize geotechnical results while providing access to all critlaal depths of construction. Tunnel lengths from 5 to 10 percent of the final design length within each distinctive geological unit should be appropriate for exploration purposes. A complete sulte of in-situ testing should be performed to establish values for all pertinent design and construction parameters.

The characterization program should also include development of adequate methods for mappling geology, water conditions, gas seepage, and drillability ahead of advancing tunnel faces, and for monttoring the overall performance of completed tunnels, shafts, and linings. Techniques and instrumentation for use in the tunnel should be designed for application during tunneling without impeding operations, rather than just during downtime of equipment. However, this capability will require development of new technology and specialized hardware. 
A comprehensive geotechnical report that $1 \mathrm{~s}$ both factual and interpretive, carefully distinguishing between each, should be prepared at the end of this phase. This report will provide the basis for construction bidding and final detalled design.

\section{Phase III Construction}

It is expected that construction will proceed on a cost-plus or costrelmbursement basis, because preconstruction information will be insufficlent to define the work sultably for fixed-price bidding. The geotechnical team should utilize advance drilling, remote sensing, and post-construction monitoring to validate predictions of face conditions and to profect possible trouble areas. The team should also establish the pay schedule according to conditions actually encountered during construction.

Exploration must be a continuous and integral part of the construction process. As linformation and data are developed, the results should be used to modify construction techniques and the design, as appropriate. The exploration program should be designed, however, to minimize 1ts impact on the construction schedule. For example, monitoring instruments could be installed during maintenance perlors to to prevent interference with mining progress. Fuither, every opportunity must be pursued to continue development of remote techniques to predict groundwater conditions, locations of critical discontinuities, and changes in drillability ahead of the advancing tunnel.

Phase III of the program should be completed with a comprehensive report of as-built conditions. The report should include the construction history, detalled geologic mapplng, areas vulnerable to problems in the future, and any geotechnical concerns bearing on responsiveness to hostile c1rcumstances.

\section{Phase IV Post Construction}

Geotechnical responsibilities will continue for the service life of the profect. During routine operations, monitoring of convergence/stress, water inflow, gas inflow, selsmicity, support systems, and chemical and physical deterforation of geotechnical components will be required. In addition, any anomalies encountered during construction should be observed for posstble effects. The information garnered during operations will provide feedback useful to projects anticipated or under way at additional sites.

In the event of hostilities, geotechnical knowledge will be vital to the continuing operation of the installation. Geotechnical skills and data will be necessary to assist in determining point of Impact and ground shock intensity, changes in hydrology, stress, and temperatures, and in evaluating drainage. Here, archival information and experienced personnel regarding the underground environment will be invaluable to strateglc and tactical planning.

\section{CHARACTERIZATION TECHNIQUES FOR 3,000- TO 8,000-FT DEPTHS}

In general, characterization techniques and instrumentation that are sultable for shallow depths (less than $3,000 \mathrm{ft}$ ) can be applied satisfactorily at greater depths. The rock mass and support response can be profected to the greater depths and the approprlate modifications incorporated into the techniques and instrumentation. However, several key environmental factors may 
be introduced that are unique to deep-underground projects. These factors include the potential for (a) corrosive waters, (b) very high operating temperatures and, for strategic facilitles (c) high shock loads and (d) high electromagnet1c pulse (EMP) loading. The abllity to evaluate these factors w1ll require specialized tests, techniques, and instrumentation.

Testing and instrumentation programs during the geotechnical exploration, construction, and operation phases of the profect will require extensive use of boreholes. Determination of the location and number of boreholes for characterization can be alded by the use of decision analysis techniques. Statistical correlations and analyses of borehole data, such as with the Rriging method, w1ll 1mprove geologic extrapolations between boreholes and help 1dentify the best locations for additional borings.

\section{Testing and Measurement Techniques}

\section{DYNAMIC}

Dynamic tests should be conducted to obtain rock mass properties and to assess behavior characteristics such as ground shock attenuation and block motion under dynamic loads. These determinations should also be used to evaluate various types of structural 11nings. Appropriate dynamic techniques include the following:

- specialized geophysical logging to obtain dynamic elastic moduli (3-D velocity) and selsviewer logs to obtain fracture orlentation.

- speclalized geophysical surveys both in vertical holes from the surface and in horizontal holes at depth (e.g., vertical selsmic proflling [VSP], tube wave veloc1ty surveys, and cross hole surveys).

- high explosive tests at surface, with appropriate instrumentation over a range of depths to measure stress, velocity, acceleration, displacement, and attenuatior.

- high explosive tests at depth to measure rock mass properties, attenuation, block motion, and dynamic joint properties.

- high explosive tests at depth to measure response of in-place structures to a shock environment.

\section{HYDROLOGIC}

Hydrologic tests are required to measure characteristics of groundwater flow and to evaluate flow characteristics of fracture systems. Fracture systems have been found to play the dominant role in control of groundwater inflows in crystalline rock and in highly fractured rock masses. The types of tests will viry, depending on the effective porosity and pexmeability of the rock matrix and the intrinsic fracture/fointing system. Pressure and injection tests should be used to obtain hydraulic conductivity and storage coefficients of fracture zones. Formational-pump, constant-head, and slug tests can be used for zones of high permeability. Translent-pulse or slug withdrawal tests should be used for the tighter formations, or zones with little fracturing/ jolnting. 
THERMAL

Thermal measurements of the rock and fluids in the rock are required for environmental monitoring and to assist in establishing the range in which temperature-dependent rock properties are to be determined. Thermal conductivity, heat capacity, and the coefficient of thermal expansion are required for rock at and near excavation surfaces and for each of the distinctive types of earth materials between the ground surface and the underground excavations. Measurements should also be obtalned from boreholes drilled for other tests. The design of the measurement program should assume anisotropy unless and until accumulated measurements indicate otherwise.

\section{IN-SITU STRESS}

Traditional techniques for measuring in-situ stress cannot be used for stress determinations in deep boreholes. Hydrofracturing is the only direct measurement technique currently avallable that is applicable under such conditions. Stress data from hydrofracturing should be supplemented by other indirect stress determination techniques using oriented cores, such as differential strain curve analysis (DSCA) and anelastic strain recovery (ASR). Borehole observations of sldewall elongation or spalling and wellbore breakout also can be used to determine the orlentation of the horizontal stresses. In a vertical borehole, core discing is an indication of high in-situ horizontal stress.

\section{IIMITATIONS TO TESTING AND MEASUREMENT TECRNIQUES}

The greatest obstacle to testing and measurement is presented by the extent of the rock mass that is subject to evaluation. For strategic facilities, sultable means to assess attenuation is an additional concern. To address the major $11 \mathrm{mitations}$ of current testing and measurement techniques, it is necessary to:

- develop dynamic in-situ tests to characterize the rock mass over tens of meters.

- design a dynamic test to obtain attenuation properties of a rock mass volume at the stress levels of interest.

- Improve current methodology and techniques to determine (a) a 3-D fracture system within the rock mass away from the borehole/tunnel, and (b) the hydrologic, thermal, and thermomechanical characteristics of iarge volumes of rock.

\section{Instrumentation and Monitoring Techniques}

\section{DYNAMIC}

The capability to assess the dynamics of the rock system is of primary 1mportance to the long-term structural integrity of the facility. For strategic purposes, monltoring is essential to address degradation of the rock mass because extensive degradation may not allow it to function as a viable structure following hostilities. An instrumentation and monitoring scheme should encompass the rock mass, the support system, and ancillary facilities. Devices that may be incorporated into this scheme include velocity gages, stress gages, accelerometers, and large block displacement or shear strips. 


\section{HYDROLOGIC}

Changes in the hydrological regime are a prime concern during construction, normal operation, and following hostilities. Inflow exceeding handling and disposal capabilities could readily lead to problems ranging from difficult to catastrophic. It is doubtful that gravity drainage will be possible at a depth of $8,000 \mathrm{ft}$. Therefore, flow meters should be installed and pumping water monitored for careful control of the hydrological regime. Sealed plezometers should be installed in boreholes within the facility, particularly at critical locations (e.g., power plant, command and control centers). Active dewatering throughout the service life of the structure is necessary, regardless of natural drainage conditions. Th1s will enhance shock absorption capabilities of the facility. In addition, continued pumping will enlarge the "cone of depression," thus alding in both temperature and water control, particularly if an aquifer is magmatic in origin as opposed to surface recharge.

\section{THERMAL}

Temperatures of the rock and the flulds in the rock should be monitored at the surface of the underground excavations and in boreholes extending from the excavation surface to depths of up to several diameters of the excavation. In addition, temperatures should be monitored from the ground surface down to the excavations in vertical intervals sufficiently small to characterize each distinctive vertical temperature gradient.

\section{STRESS/STRAIN}

Stress/strain changes in the rock mass and support system are important parameters, both throughout the life of the structure and during and after host1l1t1es. Rock mass response to loading may be deduced from changes in support stress. Several techniques are readily avallable to obtain support and rock mass measurements. Sultable instrumentation includes pressure cells and embedded strain gages in the liner or backpacking systems, strain gages in steel liners, sets or bolts, and rock mass stress change devices installed in boreholes.

\section{DISPLACEMENT}

Displacement of the rock mass is a very rellable parameter for assessing longterm performance of the structure and response to extraneous loading. Devices to measure displacement are perhaps the most developed of any geotechnical measurement systems and are the most straightforward in terms of data analysis and interpretation. Multi-station extensometer arrays should form an integral part of the facility monitoring system, both during and after construction. A 5- to 10-year operating 11 fe is reasonable for displacement monitoring systems in adverse environments.

\section{CHEMICAL}

The chemical regime, both inftial water and rock chemistry, should be monitored closely. Attention should be devoted to alteration in the regime, especially as might apply to suppor: systems (e.g., steel, grout). The approach may 
consist of something as simple as pH monitoring of facility discharge or monitoring of particular chemical constituents such as chlorites, sulfates, and carbonates. Specific concerns would be the possible effects of long-term seepage which may be corrosive or the presence of water in confunction with stray electrical current.

\section{LIMITATIONS TO INSTRUMENTATION AND MONITORING TECHNIQUES}

The major overall 11mitation of instrumentation and monitoring schemes is instrument performance over both the short and long term--a direct function of the facility environment. For the long term, the limitation would encompass all devices to some extent, but particularly electronics subject to hot, corrosive water and perhaps to EMP. Other constraints are that stress change measurement in boreholes is marginally successful and that dynamic stress changes are poorly understood. Data transmission over long distances is fust now being perfected with multiplexed digital transmission over fiber optic cable. In-shaft data acquisition might be particularly difficult due to the effects of falling debris on the instrumentation.

\section{SUMMARY}

Geotechnical characterization plays a key role in all stages of the development of deep-underground facilities, from inftial reconnalssance and site selection through post-construction. A well-developed, 1terative, systematic approach to explorations and review, comblned with the use of qualified personnel, provides the basis for design and, more importantly, ldentifles factors which could make the project unsafe or impractical to build and/or maintain.

The principal focus of geotechnical investigations should be on in-situ testing during construction of primary openings and follow-up validation of structure performance in a rock mechanics test bay. This approach will yield a much larger data base on design factors related to construction than can be achleved by ground-surface based measurements. In-situ testing integrates the effect of rock mass discontinuities into measured response. Quantifying the scale effects is not critical for construction but can result in lower costs, improved safety, and increased chances for a successful project.

Although many of the currently avallable techniques are applicable to the proposed program, improvements in site characterization technology are needed for the depths envisioned. These improvements include development of instruments which work longer under adverse environmental conditions, new techniques for evaluating in-situ stress and shock attenuation, and methodology to determine remote fracture systems in 3-D. Equally important is the use of enlightened contracting practices which permit the investigators, designers, and contractors to work together to solve the geologically based problems as they occur. 


\section{DESIGN CONSIDERATIONS}

Th1s working group was responsible for assessing the design technology for stable underground openings at depths greater than $3,000 \mathrm{ft}$, and possibly as deep as 8,000 ft. Dellberations focused on the overall design process and the major features of design pertaining to opening stability. Throughout, design was viewed as an 1terative and interactive process that requires close ties witr. geotechnical characterization and construction activities.

It is expected that preconstruction geotechnical investigations will be limited inevitably because of the depths envisioned for the proposed profect. Consequently, the initial design approach must be based on generic or assumed typical conditions. The requirements of this approach include:

- characterization of the typical classes or types of potential ground fallure conditions anticlpated throughout the site.

- description of typical rock relnforcement or support for each type of anticlpated fallure mechanism.

- estimation of the quantities of each typical support section likely to be encountered along the profect route.

- determination, during construction, of typical support or reinforcement (1ncluding no support) that is most approprlate for the actual ground conditions encountered.

- monitoring of the response of the ground and support systems, leading to validation or modification of the initial approach.

Efficlent implementation of the design will require careful consideration of the contractual format under which the construction takes place. Attention should be directed towards the recommendations contained in a previous study of contracting practices (USNC/TT, 1974), as well as to the system currently being used for the Rogers pass tunnel project in Canada. For that profect--where similar constralnts apply as for the project considered here--the contract documents anticipate the types of construction problems, provide means for resolution, and permit contractor compensation in the manner that costs are incurred.

D.S. Nat1onal Committee on Tunneling Technology. 1974. Better Contracting for Underground Construction. Washington, D.C.: National Academy Press. 


\section{DESIGN PROCESS}

The design process is a sequence of activities undertaken with the objectlve of insuring stable underground openings for the life of the structure. Preconstruction design will be based on generic or typlcal conditions. Subsequently, the initial assumptions will be revlewed and refined during construction as site characterization data are developed. The process design is tre same for both the preconstruction and construction phases, but the level of detall is slgnificantly different.

The design process begins with an examination of site characterization data with an eye for potential fallure mechanisms over the proposed layout. The type of fallure mechanism is the basis for selecting the analytic technique approprlate for estimating the rock response to loads during and after construction and, ultimately, selecting the type of support for the structure. The analytic technique dictates the type of data input needed to arrive at support requirements. Instrumenting areas both during and after construction provides an objective means of valldating and, if necessary, modifying the initial design analyses and support recommendations. The type of information required from instrumented areas depends on the analytic technique.

Table 1 summarlzes the design process, listina the common fallure mechanisms encountered in underground construction with the appropriate methods of analysis and the data input requirements for the analysis. Typlcal support methods for the various fallure mechanisms are noted by cross reference to Table 2.

TABLE 1 Major Features of the Design Process

\begin{tabular}{|c|c|c|c|}
\hline Fa1lure Mechanism & Method(s) of Analysis & $\begin{array}{l}\text { Data } \\
\text { Input }\end{array}$ & $\begin{array}{c}\text { Typ1cal } \\
\text { Support Systems* }\end{array}$ \\
\hline Structural & $\begin{array}{l}\text { Rinematics } \\
\text { Empirical }\end{array}$ & (a) & $1,2,3$ \\
\hline Strength/stress & $\begin{array}{l}\text { Stress analysis/fallure } \\
\text { criteria/fallure mode } \\
\text { Emplrical/experlence }\end{array}$ & (b) & $2,3,4,6$ \\
\hline Fault/shear zone & Empirical & (c) & $4,5,6$ \\
\hline Time-dependent & Stress analysis & (d) & $4,5,6$ \\
\hline \multicolumn{4}{|c|}{$\begin{array}{l}\text { *The numbers correspond to the types of support listed in Table } 2 \text {. } \\
\text { (a) unconfined compressive strength or appropriate material behavior } \\
\text { model; spacing, orlentation, condition (persistence, separation, rough- } \\
\text { ness, weathering, filling) of jolnts; groundwater flow and pressure. } \\
\text { (b) deformation modul1, intact strength properties, rate dependent prop- } \\
\text { erties (dynamic/creep), folnt properties, anisotropy, in-situ stresses. } \\
\text { (c) nature and distribution of faults. } \\
\text { (d) creep/relaxation modul1, "aging" of material properties, dynamic. }\end{array}$} \\
\hline
\end{tabular}




\section{Fallure Mechan1sms}

Four Eallure mechanisms are 1dentified in Table 1: structural, strength/ stress, fault/shear zone, and time-dependent (squeezing/swelling/ creep). - Structural " refers to fallures that are of kinematic origin precipitated by an adverse combination of Joint and opening geometry. "strength/stress" refers to the sitilation where in-situ stress exceeds the rock strength in such a manner as to pose a threat to an opening. The progression of local failure to threatening proportions may involve brittle fracture and strain softening or flow in a ductile manner. Both modes are possible but have different consequences for support loading. "Fault/shear zone" refers to a fallure mechanism activated when a heading enters an unsuspected fault zone possibly containing a large volume of water, sand, or clay. "Time-dependent" refers to failures that may result from (1) degradation of material properties as a consequence of diffusion processes collectively known as "aging," (2) a viscous component cf deformation, creep, or plast1city, and (3) dynamic overstressing.

\section{Analyt1c Methods}

Structurally controlled fallures may be anticipated by an analysis of the folnt block kinematics in a systematic way using limiting equilibrium analysis (key block theory) or by empirical correlation with rock mass classification schemes.

Stress controlled fallures require calculation of the displacement, strain, and stress changes about an opening as 1 t is excavated. The complex1ties of the problem likely will require the use of computer-based techniques such as the finite element, distinct element, and boundary element methods. The stress changes, when added to the pre-excavation stresses, allow for a comparison with strength, if done purely elasticaliy. If done elasticplastically, an estimate of the extent of progressive yielding is possible. The extent of the yleld zone (if any) as excavation proceeds is an important design ald.

Fault zone fallures lack consistency in elther their geometry or the nature of the materials involved. Such fallures are best handled emplrically as encountered, because each occurrence usually presents unique character1st1cs.

Time-dependent fallures require an analysis of stress that includes time-dependency in the constitutive equations (stress-strain relations) in the form of time-dependent material properties or viscous deformation. Dynamic or translent loading usually implies inertial forces and wave effects. However, a quasistatic loading analysis may be adequate, depending on the nature of the transient.

The excavation sequence followed during construction may lead to stress concentrations significantly different from those associated with the final excavated geometry. For example, a tunnel/tunnel intersection, if formed by advancing one tunnel towards the other, creates a situatior. where the advance is towards a zone of high stress concentration on the rock being mined as well as on the rock that remains after completion of the structure. A preferable sequence would Involve advance away from zones of high stress concentration. For this reason, stress analyses that account for the excavation sequence are needed $t_{i}$ order to quantify stress changes induced during construction as well as those associated with the final, fully excavated geometry. 
Data Requ1red

Two types of data are required for input: inltial data to perform an analys1s, and monitoring data to update design as well as warn of lnstab1lity. The data input includes:

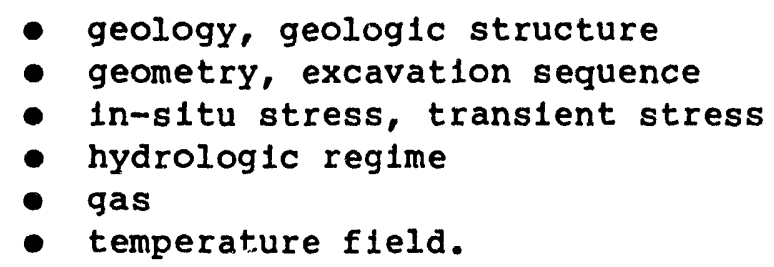

These data are common to each method of analysis that 1 s part of the design process. More specific needs for each method are detalled in Table 1 and include material properties. In this regard, data for the entire site cannot be obtained with adequate precision; therefore, an estimate of the variation in properties should be developed during geotechnical characterization as an ald to quantifying uncertainties.

\section{EFFECTS OF DEPTH}

The design concerns assoclated with the more common, "shallow" civil construction differ from those expected at the depths envisioned for construction of the proposed project. There are three primary features of design which reflect these differences.

First, the fallure mechanism shifts from a structurally controlled (kinematic) process to a strength/stress controlled process with increasing depth. The fallure of openings is driven mostly by gravity at shallow depths. At greater depths the fallure mechanism is driven more by the ratio of rock mass strength to the induced stress.

Second, temperature increases w1th depth and the virgin rock temperature (VRT) might approach $130^{\circ} \mathrm{F}$. Thermal stresses associated with VRT levels of $130^{\circ} \mathrm{F}$, or less, should not adversely affect the design of openings and support systems. The exception, however, lies in potential increases in rates of rock creep.

Third, the presence of water at depth can be assoclated with excessively high pressures and flow rates. Elther occurrence can lead to the potential for liner fallure. Water inflows must be elther stopped (e.g., grouting, heavy liners)--which is an expensive and unlikely solution--or drained, a more reasonable scenario.

These three features are consldered unique to deep construction and must not be 1gnored because they may prohibit opening stablilty and construct1bility. Existing design technologies are adequate to handle the issues but are by no means perfect. There are research and development needs that should be addressed. It is essential, in any event, that the issues be recognized at the earllest possible stage of the design process. 


\section{SUPPORT SYSTEMS}

The design of the support system should be versatile, so that the most appropriate method(s) for support can be determined on the basis of the varlous rock conditions actually encountered during construction. This approach requires that excavation equipment accommodate installation of a $\mathrm{m} 1 \mathrm{x}$ of support systems in concert with excavation.

The support systems appropriate for typlcal categories of ground condtions (or fallure mechanisms shown in Table 1) are outlined in Table 2 . Within these systems there can be variations. For example, Type 3 ground support may include more closely spaced rock bolts and wire mesh rather than rock bolts and shotcrete. In this case, the variation may resolve a conflict between maximum tunneling efflciency and the desirability of shotcrete.

TABLE 2 Reguirements for Typical support Systems

\section{Category system}

Type 1 Unsupported except for spot rock bolting of occasional loose blocks.

Type 2 Rock bolt pattern (w1re mesh required occasionally).

Type 3 Rock bolt pattern with shotcrete layer (and wire mesh).

Type 4 Shotcrete applied immediately after excavation.

Rock bolt pattern and wire mesh.

Monitoring of deformation.

Second shotcrete layer placed after rock has stabilized (1f required).

Type 5 Splling/steel sets.

Cable bolts (long).

Ground stabilization by grouting (if required).

Final encasement (if required).

Drainage.

Type 6 Yieldable rock bolts in conjunction with shotcrete and wire mesh. Monitoring of support performance.

However, it should be recognized that within each rock category there may be diverging opinions as to the particular support system to be installed. Therefore, it is important that clear author1ty be established to direct the contractor as to support requirements for a given condition. This authoritative responsibility, including provisions for appropriate payment, should be assigned elther to one individual or to a small group (two or three individuals). 


\section{Shafts and Intersections of Openings}

Support for shafts and intersections of openings (tunnels/tunnels, shafts/ tunnels) w1ll require interactive design and systems similar to tunnels. However, some differences must be considered.

For shafts, the major difference is that the support system would encompass the full circumference of the wall in all cases. During design, particular attention must be devoted to in-situ horizontal stress. To prevent small rock falls during construction, a shotcrete layer can be applied which could also serve as a portion of the support system. Another common safety measure is to bolt wire mesh between the lining and the shaft bottom. Permanent concrete lining will insure long-term stability.

For intersections, the main difference in support design arises from higher stress concentrations than would be encountered in similar rock in a tunnel. The support requirement increases as the angle of the intersection decreases from 90 degrees.

\section{Spectal Concerns}

Groundwater must be accounted for in support system design. For any system that seals the rock and does not allow free drainace, the lining must be drained or designed to withstand the pressure. At depth, the hydrostatic pressure can be high and the heavy liners required to resist the pressures would be extremely expensive. Therefore, drainage and disposal of water inflow should be considered in support design. Drainage should also reduce the amount of free water avallable in the rock after dynamic loading, a matter of interest for strateglc facilities.

The hardening system of strategic facilities is logically related both to the support system and to the rock mass. If a hardened section includes rock bolts, then a portion of that pattern may be used as initial support. If rock bolts are not included, but a hardening system will be installed, then a thinwall full column support or point anchor bolts may be used. Consideration should also be given to flexible versus rigld support systems.

The geometric aspects of tunnels, shafts, and intersection(s) layouts are important to opening stability. The proximity of multiple openings will affect the concentration of stress around each opening. In addition, the angular relationship of intersections (tunnels/tunnels, shafts/tunnels) affects stress concentrations and the extent of yleld zones. Acute intersection angles and multiple intersections should be avolded. When such situations are unavoldable, special support systems such as steel sets and bullt-up reinforced cribs may be required.

\section{MONITORING FOR INTERACTIVE DESIGN}

The inftial design may be developed reasonably on the basis of the necessarily limited site and geotechnical information avallable prior to construction. The various classes of support are predicated on estimates of the behavior of the expected fallure mechanisms. However, the geomechanlcal behavior of the rock as actually exposed during construction, as well as the interaction between the ground and the support, w1ll vary from the assumptions of the 1nitial design. Monitoring and evaluation fleld instrumentation measurements will permit 
adjustment of the initial assumptions according to performance, leading to a closer correlation between estimated and actual rock response and support requil rements.

The primary elements of initial rock support during construction (v1z., rock bolts, mesh, and shotcrete) are readily varlable as to spacing or thickness. Consequently, during construction it is quite feasible to modify support quantities based on evaluation of monitoring instrumentation, thereby securing optimum support and economy both in the near term and over extended periods of time.

The monitoring program should be designed to determine the performance of the combination rock/support systems. The progran should incorporate the following instrumentation as a minimum:

- convergence points--to verify movements of the supports and rock at the periphery of the opening.

- multiple position extensometers--to verify rock mass movements away from the tunnel surface.

- rock borehole and/or liner pressure cells--to measure stress changes indicative of load transfer.

- plezometers--to monitor water pressure bulldup.

\section{RESEARCH AND DEVELOPMENT}

Research and development to assist the design of deep underground fac1lities should include the following efforts:

- Nonborehole geophysical systems (e.g., ground probing radar) need further development for use at the face to 1dentify major geologic features ahead of excavation. Also, surface and borehole geophysics need improvement for more effective site characterization. Electromagnetic (radar) surveys, being sensitive to water, could be used to locate saturated faults in an unsaturated rock environment.

- Case-history information (e.g., stab1lity, rock/support interaction) on deep excavations should be collected and evaluated.

- Constitutive laws need better formulation and/or development for all types of geologic materials, and especially for rock types expected to be encountered at great depths.

- Computer programs for analysis of a jolnted rock mass and support response under large displacement (and possibly large-strain dynamic loads with progressive fallure by caving and flow) should be developed and the accuracy of computed constitutive behavior should be checked against case-h1story data.

- High speed, low profile diamond drills need to be developed for instrumented boreholes near the face (just behind the machine).

- Fallure mechanics of a folnted rock mass, particularly at high stress levels, require research. Improvements in knowledge of failure criteria and in methods for analyzing the interaction between the rock mass and the installed sunport system are necessary for designing more effective support.

- Yieldable support elements (e.g., foam concrete, point-anchored, strlppable, threaded bolts) require research to determine capabilities for integration into the support system. Th1s is a prime concern for deep fac1l1ties in view of the high in-situ stresses expected and the potential for high 
dynamic (or quasistatic) loading. Conventional support designs usually feature "rig1d" systems (exceptions beling yleld arches, wood cribs, etc.). Support elements such as full-column and point-anchored rock bolts, cable bolts, shotcrete, concrete linings, and steel sets offer significant resistance to ground deformations and are considered "rig1d." In the highly yielding ground that may be expected at great depths, large deformations may cause fallure of the support elements and perhaps catastrophic fallure of the opening as well.

\section{SUMMARY}

The technology exists to design stable underground openings to depths of 8,000 ft. However, this technology is not equivalent to ordinary tunnel design at relatively shallow depths, where sufficient support can usually be marshalled to overcome difficult conditions. Increasing depth requires increasing attention to design principles. Quantitative knowledge of rock mass and support behavior becomes more 1mportant, and rellance on the natural support provided by the rock as well as on the installed support becomes essential to stability.

The designers must recognize that the factors affecting opening stability become significant at depth. Therefore, data developed during the site characterization stage must be used to maximum effect in order to avold early construction difficulties and attendant delays. Interactive design accompanied by instrumentation and monitoring of the rock/support system is essential to design validation and modification.

The instrumentation layout must be planned and implemented in a staged design so that the data expected are provided in a timely manner that allows practical use during construction. Here, deep-mine case histories and related experience are pertinent. Monitoring data should also be used to warn of impending instability.

Finally, it is important that construction philosophies be reoriented towards a deep mining perspective. Deep openings may undergo large deformations, and support systems must work with the ground (1.e., yleld) rather than resist the inevitable movement of rock into the openings. 


\section{CONSTROCTION ISSOES}

The constructibility of a deep-underground profect will be determined, ultimately, by two factors:

- site geotechnical conditions

- facility layout and design.

The s1te characterization program must account for the geotechnical/geological parameters and physical properties of the rock mass in terms of influence on construction methods and sequence. The layout and design of the facllity must permit efficient and rapld performance of excavation and support operations.

\section{GEOTECHNICAL EXPLORATION}

Detalled site exploration for construction of a deep-underground facility can be accomplished most effectively by placing a shaft and adit so that the rock conditions to depth can be observed directly, in situ. If time is a constraint and several sites are candidates, 1t may be desirable to place shafts at each site so that the final decision can be based on in-situ observations. Smalldiameter shafts have been drilled to depths of Interest at Hot Creek, Nevada (5,500 ft deep; 120 in. diameter) and Amchitka, Alaska (6,150 ft deep; 90 in. diameter).

Exploratory shafts and adts provide direct evidense of the source and magnitude of water inflows. Preconstruction excavation also offers an opportunity to observe the larger-scale rock features that significantly affect construction but cannot be evaluated from borehole data, such as the continuity and waviness of joints and the extent and character of weak zones. For the designer and contractor, the ability to inspect the rock mass and determine significant geotechnical conditions is an important benefit.

An exploratory shaft installed prior to the main construction contract can be used to advantage during construction. It can provide early access to the tunnel level as well as serve ventilation and mucking operations throughout the construction period.

\section{S1te Characteristics}

A major purpose of the geotechnical exploration program $1 \mathrm{~s}$ to determine s1te characteristics that bear on excavation and support procedures. In selecting a 
site or locating a facllity at a given site, the occurrence of certaln cond1tlons should be viewed as distinct disadvantages for construction. Even if not defined as "fatal flaws," these conditions can have a substantial negative 1mpact on construction operations, cost, and schedule. Therefore, if possible, profect siting should not be consldered in areas that feature:

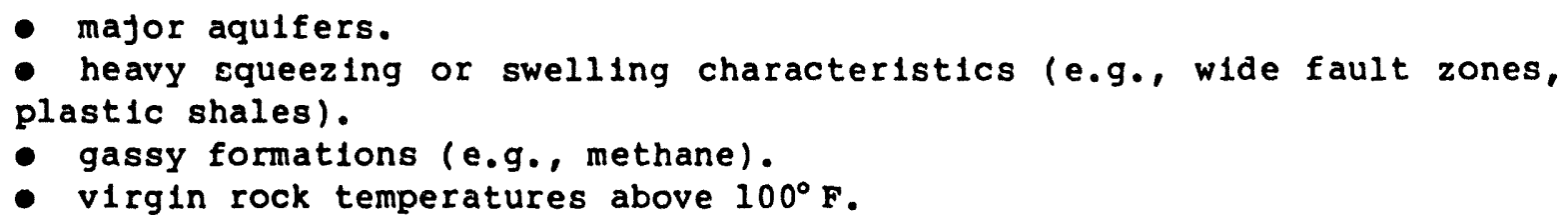

Large quantities of water at depth are difficult to handle and are hazardous when suddenly encountered during construction. Siting the profect in or near sources of substantial water such as major aquifers and heavily faulted ground should be avolded. When fault zones must be penetrated, the opening should be orlented to $\mathrm{min} 1 \mathrm{mize}$ distance $\mathrm{in}$ faulted ground. Heavy squeezing and swelling of the host rock impedes the performance of most tunnel boring machines with rigld, cylindrical bodies. Gassy formations are dangerous and slow productivity because extensive safety precautions are required to protect crews and equipment. High temperatures increase the ventilation and cooling modifications necessary to maintain the efficlency of the construction operation.

other conditions that will adversely affect construction, but perhaps to a lesser extent than those indicated above, include the following:

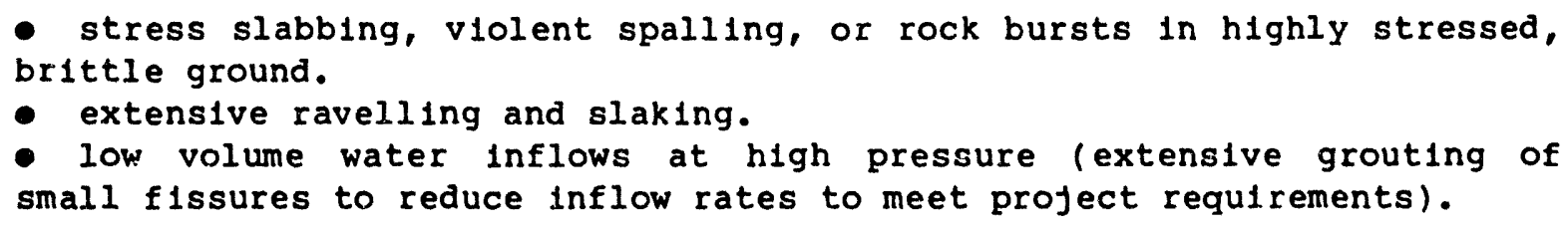
brittle ground.

- extensive ravelling and slaking.

- low volume water inflows at high pressure (extensive grouting of small fissures to reduce inflow rates to meet project requirements).

None of the conditions noted will preclude construction provided that sufflclent time and finances are avallable to manage the consequences. St1ll, from a construction standpoint, the most desi:able course is to refect sites where major occurrences of the conditions are fudged likely to exist, based on avallable geotechnical information.

Minor occurrences of any of the conditions can be accommodated. However, the presence of water or gas always warrants special consideration for potential to impede construction as well as to create problems during operation of a facllity.

The "1deal" location would be an area with a relatively low, average amb1ent surface temperature and a low or average subsurface temperature gradient. The subsurface would be free of water and gas, the rock would be competent and machine boreable, and the rock mass would be free of major discontinuities. These favorable characteristics would be predictable and exist throughout the entire site.

\section{FACILITY LAYOUT AND DESIGN}

The design and layout of an underground profect is a primary means of promoting efficlency, economy, and safety in construction. Constant attention to this 
relationship is essential to successful completion of the facilities envisioned. Some of the actions important to complex construction operations at depth are:

- Layout the facility so that each shaft system (1.e. pair of shafts) will serve as many underground headings as possible.

- Design each shaft system to handle (a) maximum muck holsting, (b) maximum material servicing, (c) maximum personnel servicing, (d) maximum ventilation, and (e) special, major heavy/large equipment transport, including operational requirements.

- Estimate the average advance rate for multiple headings served from a single shaft at 50 percent of the rate that would be achieved under single heading, surface portal conditions.

- Maximize use of raise drilling, reaming, or slashing methods for shafts when ground conditions are appropriate.

- Avold hydrostatic liners in large openings.

- Establish rall haulage at less than one percent grade.

- Plan grades for equipment operation within suitable limits: (a) -158 and +108 maximum desirable grades for $\mathrm{LHD}$ ramp, (b) -208 and +15 maximum allowable grades for LHD ramp, (c) 208 maximum desirable grade for tunnel boring machine.

\section{Safety}

Planning for the health and safety of personnel begins early in design development for the preconstruction through post-construction stages of a profect. The 1ssue is inherent in the phased, integrated approach proposed for geotechnical exploration, design, construction, and equipment selection. However, the scope and schedule of this workshop permit only the briefest acknowledgment of questions related to safety. Therefore, a partial list of design objectives for stability and constructibility is presented here as a means of highlighting the range of factors to be accommodated in plans for a healthy and safe working environment:

- Layout parallel openings with connections, where possible, to ald ventilation and provide emergency escape ways.

- Plan machine mining for shafts, if possible.

- Provide for immediate installation of adequate initial support.

- Maintain heat (wet-bulb temperature) at the face within acceptable limits; prepare contingency stand-by power and evacuation plans.

- Limit encounters with very highly stressed, brittle rock (potential for severe popping or bursting).

- Minimize exposure to heavily faulted ground where sudden, high inflows of water could be encountered; probe for water where expected.

- Nonitor the presence of radon and other gases and plan for adequate dilution; avold siting in gassy formations, if possible.

Hazardous situations may develop with little advance notice and escalate rapidly. Even though the probability of occurrence may be small, it is essential that trained personnel and appropriate equipment and supplies be readily avallable to handle emergency conditions. 


\section{EFFECTS OF DEPTH}

At the depths envisioned for this facility, conditions will differ from those assoclated with common, civil construction. Depth produces changes in the rock enviromment and imposes consequences for project execution that may influence construction requirements, efficlency, and costs. The factors of concern at depth include temperature, in-situ stress, groundwater inflow, rock quality, and logistics. Their effects on the construction effort can be summarized as follows:

- Temperature--rising temperature increases cooling and ventilation requirements and decreases worker efficiency.

- In-s1tu stress--h1gh in-situ stress increases the potential for stress slabbing (formation of new fractures) and rock bursts (violent rock fallure) around the advancing opening.

- Groundwater inflow--1ncreasing pressure exacerbates the volume and rate of groundwater inflows. High-pressure flows encountered suddenly can halt construction and flood the excavation; pumping costs for significant quantities will be high. Large inflows may bring additional heat into the tunnel, ralsing the wet bulb'temperature beyond the desirable range by the process of evaporation. Groundwater inflows also tend to reduce stability of the rock blocks surrounding an opening and contribute to muck handling problems.

Decreasing permeablilty may occur with increasing depth at some sites and significantly mitigate groundwater inflows. If reduction of inflow were necessary in low permeability rock, grouting at high pressure and low viscosity would be required.

- Rock quality--improvements in rock quality typlcally develop with depth, including an increase in joint spacing and tightness and an absence of weathering, rellef folnts, and other surface features. However, some structural features may penetrate deeply, such as large fault zones which can result in heavy squeezing at depth.

- Logistics--increasing difficulty in access for exploration purposes may result in more unknowns and greater risk until access at depth has been achleved. The time required for shaft sinking and shaft operation will lengthen, with progressive impact on the project schedule. Changes in layout may be necessary for construction efficlency.

It should be emphasized that the benefits or problems associated with a deeper facility are strongly influenced by the local site conditions, such as geologic structure, rock strength, and temperature gradient with depth. For example, at some sites the strength of the rock will be sufficient to prevent stress slabbing, even though the facility is deep. The variation in these conditions from one site to another, at the same depth, may be greater than the varlation with depth at a single site.

Several factors of concern to construction at depth merit discussion in more detall. They are temperature, ventilation, and in-situ stress.

\section{Temperature and Ventilation}

In underground construction, the temperature level is influenced by several factors. The geothermal gradient at a given site determines the virgin rock 
temperature (VRT) at a glven depth. To the VRT must be added the signiflcant amounts of heat generated by electrical machinery. For example, a tunnel boring machine will produce about $20 \mathrm{~kW}-\mathrm{h}$ of heat energy per ton of rock excavated--or $6 \mathrm{million}$ Btu per hour for $100 \mathrm{ft}$ of $18 \mathrm{ft}$ dlameter tunnel per day. Heat also flows from rock strata, broken rock, and fissure water if the VRT is above the amblent air temperature.

Heat criterla based on human physiology indicate that a maximum design work area temperature of $86^{\circ} \mathrm{F}$ wet-bulb (WB) can be well supported. The temperature ranges $\left({ }^{\circ} \mathrm{F}\right)$ defined for work areas are as follows:

$$
\begin{aligned}
<80^{\circ} \text { WB } & \text { Worker efficiency is } 100 \text { percent. } \\
80^{\circ} \text { to } 86^{\circ} & \begin{array}{l}
\text { The "economic" range. An acclimatized miner can per- } \\
\text { form effectively. }
\end{array} \\
86^{\circ} \text { to } 91^{\circ} & \begin{array}{l}
\text { The "safety factor" range. Corrective measures should } \\
\text { be applied } 1 f \text { temperatures are in this range. }
\end{array} \\
>91^{\circ} \text { WB } & \begin{array}{l}
\text { Risk of heat stroke climbs dramatically. Only light- } \\
\text { duty, short duration work should be expected in } \\
\text { temperatures greater than } 91^{\circ} \text { WB. }
\end{array}
\end{aligned}
$$

For faclilties with the potential for elevated temperatures at depth, the heat must be removed or 1 solated to keep work area temperatures under $86^{\circ} \mathrm{F}$ (WB), the "econom 1c" range. Thus, it is most desirable to site the facility in strata with a VRT of less than $86^{\circ} \mathrm{F}$. The $86^{\circ}$ to $100^{\circ} \mathrm{F}$ range is acceptable, but some alr-conditioning would be required in long, dead-end, rapldily advancing headings. Construction in strata with VRTs at about $100^{\circ}$ to $125^{\circ} \mathrm{F}$ is certainly possible but apt to be very costly.

Ventilation is an immediate construction concern, requiring that a primary ventilation circult be set up quickly. The procedure involves driving at least two headings or shafts from the surface and conne ing them underground at the proper depth. A fan is then placed in the circult, which functions to provide fresh alr for the auxiliary fan system. Quantity is determined by sunming the requirements of the individual headings. In mining, drift and shaft wizes are often specifled to limit the fan operating point to a 25 to $30 \mathrm{in}$. water column.

Current ventilation technology is adequate for constructing a deep facil1ty. The cost and complexity of the system will depend on the anticipated heat load. Planning for ventilation will depend on the design and layout of the fac1lity.

\section{In-Situ Stress}

The effect of stress on stability and excavation progress must be viewed with respect to the strength of the intact rock. Stress slabbing behavior will begin to occur in brittle rocks when the unconfined strength of the intact rock is less than approximately five times the maximum in-situ stress (taken as equal to the overburden stress, in many deep projects). At this strength level, the slabs may form along the intact rock and some combination of a preexisting joint, follation feature, or bedding plane. More pronounced slabbing occurs when unconfined strengths are less than approximately two to three 
times the overburden stress. At this ratio, fracture through the intact rock alone is 11 kely.

The intensity of the popping or slabbing of the rock is a function not only of the strength/stress ratio but also of the brittleness of the rock and the total strain energy that is released as the rock fractures. For a given strength/stress rat1o, the stiffer, higher strength rocks will release more energy and result in more dynamic spalling. In rock with pre-existing fractures, the intensity of the slabbing will be less than in the more intact rock, even though the slabbing and loosening might take place at a lower threshold of in-situ stress.

Tunnels can be constructed in ground subject to stress slabbing if appropriate excavation and support prccedures are applied. TBMs can be used successfully if the cutterhead and mucking system are designed to handle slabs of the size possible under spalling and stress slabbing conditions. Short, movable shields may be preferable to long, flxed shlelds on TBMs. The support must be capable of holding the fractured rock in place. Rock bolts or dowels, mesh, and shotcrete can be used to control stress slabbing and provide support. Under stress slabbing conditions, particularly in a deep excavation, the support must be installed close to the tunnel face to protect against spalling and to minimize loosening of slabs.

\section{EXCAVATION AND SUPPORT}

In view of the size and complexity of the proposed facility, which are factors compounded by the depths envisioned, other deep underground profects should be surveyed as potential sources of useful information. For example, in North America, South Africa, and India, mines operate at depths similar to and several thousand feet greater than the maximum anticipated here.

In Europe, and to a lesser extent in North and South America, tunnel construction in mountalnous areas has involved ground cover that is deep by the standards for this project. For example, the old Connaught Rallroad tunnel ano the new Rogers Pass tunnel are at depths of 4,000 ft in schists, with follation trending across the tunnel axis. The connaught tunnel was excavated largely without support, although a protective lining was later installed to prevent falling of rock pleces loosening in the tunnel arch. The rock showed no evidence of significant stress problems. In a different type of profect on Amchltka Island, chambers were excavated at a depth of 5,000 ft without spalling problems related to high stresses.

For the most part, TBMs with long, fixed shields have not performed well in deep tunnels in which the ground was subject to squeezing and slabbing induced by stress. Either squeezing or loosening of slabs around the perimeter of a long shield can cause the TBM to stall. Furthermore, once the slabby rock emerges from behind the tall of the shield, it is often so loosened that it is difflcult to support in place. In South Africa, operation of TBMs at great depth (1.e., 9,000 ft) was unsuccessful due to effects of both temperature and stress.

Recently, TBMs with short shields and the capability of placing support close to the cutterhead have performed well in ravelling and squeezing ground. In the stillwater tunnel, at a depth of $2,000 \mathrm{ft}$ in a raveling and moderately squeezing shale, progress over a period of months averaged in excess of $150 \mathrm{ft}$ 
per day using a TBM with a short canopy, whereas a TBM with a long shield had been slowed and was finally unable to advance in the same ground conditions.

For shaft sinking, the diversity of profect experience 1 s more $11 \mathrm{~m} 1 \mathrm{ted}$ and contractor experience is $11 \mathrm{~m} 1$ ted even more so. Generally speaking, only a few contractors in North America have sunk single lift shafts to depths greater than $6,000 \mathrm{ft}$.

\section{Tunnels}

The facility should be deslgned to take advantage of the capabilities of tunnel boring machines. Long runs of tunnels with clrcular cross section and constant diameter are desirable. There may be advantages if palrs of tunnels are driven together, with cross adits connecting the two. For example, an opportunity may be provided to perform both the excavation and lining operations simultaneously, at different locations in the tunnel. Further, access to and egress from the heading is improved, groundwater inflows are more readily controlled, exploration can be carried out ahead of the tunnels, and ventilation may be enhanced.

Generally, the abllity to place ground support 1mmediately behind the face becomes more important in a deeper facility because the potentlal for instability increases with depth. Fully resin-grouted or friction anchor bolts can be installed immediately behind the cutterhead of the TBM. Wire mesh or cables tied to the grouted bolts is one means of providing protection from dynamic effects. High strength, wire fiber-reinforced shotcrete also helps to control spalling as well as to prevent loosening of slabs. A silica fume additive is useful for rebound control.

In rock subject to spalling and fracturing, and in faulted ground, it is desirable to have the capability to place shotcrete close behind the cutterhead of the TBM rather than having to delay placement until the trailing gear has passed. However, shotcrete is not normally placed around a TBM, particularly In small-dlameter tunnels, because of dust, space limltations, rebound bulldup on the machine, and limited visual ability to monitor placement. Thus, when rock bolts alone are inadequate and some intermedlate support between the bolts is required near the face, the contractor often must switch from bolts to steel ribs rather than being able to add shotcrete and retain the rock bolts. This change involves different equipment and requires a significantly different construction technique. Switching back and forth between the methods results in delays as equipment is removed and replaced and in low efficlency as crews alter their routines.

There is a contradiction here, because a tunnel lining system that relies on bulk materlals, such as shotcrete components, may be preferable for a deep faclilty. Large lining elements such as steel ribs and precast segments require increased handling time in the shafts compared to bulk materials.

Even though 1 t may be necessary to install additional support at a later time for the permanent requirements of the fac1lity, it would appear desirable to use the initial support for permanent support to the maximum extent possible. Efforts might well be directed toward developing and testing a support system that can be installed efficlently and yet has the ductility and toughness required to withstand large deformations during loading. 
Shaft sinking performance can greatly affect the total project schedule. The initial shaft must be sunk blind and will be on the critical path from start to finish. Whether subsequent shafts are sunk blind or constructed by one of several other means will depend on rock conditions, preferred dlameter, and schedule constraints.

An exploration access shaft would be the first to be constructed. Another shaft, and most likely a pair, would be required for ventilation adequate to accommodate high advance rates for multiple tunnels at depth. The shaft(s) could also serve for mucking and service operations. To achieve full production at the tunnel level as soon as possible, a shaft for exploration and one for ventilation could be blind sunk simultaneously.

In soft rock, the fastest method to put down a small-d1ameter shaft 1 s by blind shaft (large-hole) drilling. The diameter that can be achleved decreases as depth and rock strength increase. Surface drill rigs will cut rock up to $30,000 \mathrm{ps} 1$, but only at small dlameters and high costs. The diameter possible at a given depth, even though sultable for exploration purposes, may be too small to permit adequate ventilation to remove heat.

Blind shaft sinking by conventional (drill-and-blast) means is possible at diameters up to approximately $33 \mathrm{ft}$ and to depths of $8,000 \mathrm{ft}$. Th1s method 1s sultable for all the rock strengths considered here. The sinking rate would probably reach 8 or $9 \mathrm{ft}$ per day. With proper plant, the sinking rate is relatively constant, $1 . e .$, not diameter dependent.

A blind downhole boring machine is in the development stage but the technology is not fuIly proven. Such equipment is expected to perform effectively in rock up to 25,000 to 30,000 psi compressive strength. Shaft diameters of 22 $\mathrm{ft}$ and sinking rates of up to $20 \mathrm{ft}$ per day (twice the rate of conventional sinking) should be possible with this technology. Basically, like conventional sinking, the machine would work to a maximum depth of $8,000 \mathrm{ft}$, at which point hoisting limitations would be reached.

Once one shaft is sunk, is may be possible to construct a second shaft using ralse drilling, reaming, or slashing methods, depenting on ground cond1tions. Single or multiple-pass enlargement is faster than coiventional sinking and requires less heavy plant. For a deep shaft, 1 t will be necessary to install drill stations at intermediate levels. Ralse and reaming equipment has been used for shaft depths to a maximum of $2,500 \mathrm{ft}$, but poor accuracy of pllot holes is a limitation for methods requiring their use. However, technology now being developed to drill accurate pllot holes should be avallable when required. Ralse and reaming equipment has been used successfully in rock with compressive strengths as high as $50,000 \mathrm{psi}$. In soft rock, raised or reamed shaft diameters of $20 \mathrm{ft}$ are realistic; in hard rock, 15-ft diameters are possible.

In mechanically excavated shafts, the primary lining would be applied after completion of excavation and the method of application would depend on lining design. Raise, reaming, and blind drilling techniques would be used only in favorable ground and blind boring or conventional methods would be selected for use in poorer conditions.

As the depth of the facility increases, the length of tunnel driven from a given shaft should be increased to achleve an efficient operation. Multiple headings in a hub-like arrangement might be driven from a single shaft. Alternatively, fewer but longer tunnels could be driven from the shaft. 
Multiple, long headings, if simultaneously driven, will present large muck holsting and ventilation requirements. Thus, it is expected that the diameter of the shafts required will increase with the depth of the facility.

\section{RESEARCH AND DEVELOPMENT}

The construction technologles can be advanced significantly by research and development that is accompanied by demonstration profects. It is anticipated that substantial progress could be achleved in sufficlent areas so that the results could be applied to construction profects starting within a few years. Some of the most important requirements are as follows:

- Rapid methods to sink shafts.

- TBM capable of dealing with violently spalling ground.

- TBM that allows application of steel flber imbedded shotcrete 1mmediately behind the face.

- TBM that can perform effectively when rock hardness exceeds 30,000 psi compressive strength.

- Support systems that are easily installed near the face and have large alsplacement capabilities.

- Directional control of drilled pilot holes.

- Feasible means to use the heat of evaporation to cool the environment and means to transport liquified air into the headings to supplement ventilation.

- Improved techniques for heat exchange (e.g., U-tube) in vertical shafts and for transporting 1ce underground pneumatically, in order to reduce pumping of condenser cooling water.

\section{SUMMARY}

The major factors affecting constructibility deep underground are geotechnical conditions at the site and the design and layout of the facility. The characteristics of the rock mass influence construction method and sequence. Among the more adverse features are major aquifers, heavy squeezing or swelling behavior, gassy formations, and highly stressed ground subject to violent spalling. Facility design and layout influence performance of excavation and support sperations. Considerations include shaft systems for multiple head1ngs, shaft capacity for maximum transport and mucking, grades for rail haulage and equipment operation, and parallel openings with connections to ald ventilation.

Increasing depth is accompanied by changes in the rock environment that can influence construction requirements, efficlency, and costs. Factors meritIng specific attention are temperature, in-situ stress, groundwater inflow, rock quality, and logistiss. For example, rising temperature increases vent1lation requirements and decreases worker efflciency; high stress increases the potential for slabbing and rock bursts; volume and rate of groundwater inflow is exacerbated by increasing pressure; structural features such as large fault 
zones can result in heavy squeezing; and l1mited access for exploration increases the possibility of unknown conditions.

The facllity should be designed to accommodate excavation with tunnel borlng machines. TBMs with short shields may be more effective than machines with long, flxed shlelds. Long runs of tunnels with clrcular cross sections and constant diameter are desirable. Driving palrs of tunnels with connecting cross ad1ts may benefit exploration, groundwater control, and ventilation. The ab1lity to place support 1mmediately behind the face 1s important because the potential for instability increases with depth. A lining system that relies on bulk materials rather than large components may be preferable.

The construction technologies should be improved for excavation and support operations at depth. Substantial progress can be achleved through developments such as TBMs capable of dealing with violently spalling ground, more rapld methods to sink shafts, efflclent installation of support systems with large displacement capabilities, and directional control of drilled pllot holes. 
EXCAVATION EQUIPMENT AND SYSTEMS

Th1s working group was assigned the task of assessing the technical feasibility of mechanical excavation systems for the construction of deep-underground facilities. Many factors affecting equipment design and system selection were considered with particular reference to construction technology. Therefore, concepts developed herein should be revlewed in concert with those presented in preceding parts of this report, particularly the chapter dealing with construction.

In addition to the general assumptions adopted as a framework for the workshop, the group assumed that the underground facllity would be constructed with several distinct modes of excavation. Equipment requirements were consldered for each of four categorles of excavation, as follows:

- tunnels--more than $1,000 \mathrm{ft}$ in length.

- crosscut passages and intersections--short chambers or tunnels less than $1,000 \mathrm{ft}$ long.

- access shafts--vertlcal opening to surface, temporary for construction.

- Internal shafts--temporary or permanent shafts between levels, or cylindrical openings required by facility plan.

Types of cutting machines, bit or tools, and muck removal and excavation support equipment are consldered for each mode of excavation. State-of-the-art construction methods are discussed, as well as potential equipment modifications and possible applications of emerging technologies.

TUNNET CONSTRDCTION

\section{Excavation Equipment}

Four types of mechanical equipment were consldered for potential use in tunnel excavation. The types, all state of the art, are full-face tunnel boring machines, partial-face tunnel boring machines, roadheders, and impact breakers.

FULL-FACE TUNNEL BORING MACHINES

A tunnel boring machine (TBM) employs a clrcular cutterhead structure to which e1ther drag or disc-type cutting tools are attached. The c1rcular structure is 
rotated and thrust at the rock surface at the heading, causing the cutters to penetrate and fracture the rock. Torque and thrust reaction forces are taken through a structural frame to an anchoring system which braces by gripping the tunnel wall.

TBMs have been used efficlently in excavating soft to hard rock--1.e., Rock Quality Designation (RQD) values from 25 to 100 percent and uniaxial compressive strengths from 2,000 to 35,000 ps1. TBMs are generally designed for optimal performance in geological environments with limited variations in rock and rock mass characteristıcs. Some "hybriá" machines designed to accommodate a wide varlety of rock conditions have been used also, but with varying degrees of success. Thus, the site selection process should 1dentify and exclude locations with widely varying rock characteristics.

The technology exists today for efficient excavation of c1rcular headings at average advance rates between 100 and $200 \mathrm{ft}$ per day. On a specific project, the advance rate will depend on the design of the excavation system, the tunnel lining required, muck haulage capacity, contractor scheduling, and human factors. To allow for the most rapid advance, the bored tunnel should be $10 \mathrm{ft}$ in diameter at a minimum.

Recent modifications incorporated in TBM system designs include the following:

- disc cutter arrangements which reduce radial loads on the main bearIng, increase penetration, and reduce cutter wear.

- rear-mounted cutters which can be replaced from the rear of the cutterhead, decreasing excavation delays.

- dust control systems which incorporate double dust shields with suction on the rear shield.

- hydraulic systems which minimize space and maintenance requirements and heat production.

- stepped or variable drives which provide a range of cutterhead rotation rates and may increase penetration in rock masses where machine progress is not $11 \mathrm{~m} 1$ ted by avallable torque.

For long tunnels with gentle alignment curves (radius greater than about $300 \mathrm{ft}$ for an unshielded machine) and grades not exceeding 20 percent, a fullface, disc-cutter-type TBM is the most viable excavator. Trailing floor components are generally of Ilmited flexibility, however, and larger radif curves (about 500 to $600 \mathrm{ft}$ ) may be required to allow adequate clearance for the equipment.

For ramps and slopes, TBM design can be modifled to provide efficlent performance at grades up to about 27 percent (15 degrees) downgrade and about 100 percent ( 45 degrees) upgrade. Upgrade excavation on steeper slopes can be accomplished with blind shaft boring equipment, which is discussed later in this chapter. Excavation in an upgrade direction is preferable because it eases muck handling and water disposal and reduces power requirements.

PARTIAL-FACE TUNNEL BORING MACHINES

Partial-face TBMs ut1lize disc or pick-type cutters but attack only part of the rock face at the heading at any one time, using a horizontal or vertical sweeping motion to complete the full face. Circular cross section, partial-face cutting equipment has been used successfully in Europe. One partial-face 
machine which cuts a rectangular opening currently is undergoing trials in Australia. Because only a few cutters are in contact with the rock at any time, thrust and torque requirements are less than for a full-face TBM. Therefore, compared with a full-face machlne, partial-face TBMs can be lightwelght and highly maneuverable equipment. However, the limited installed power results in correspondingly low advance rates. Th1s equipment may be used more efficlently in shorter tunnels and crosscuts, where maneuverability and short mobilization time are of prime importance.

\section{ROADHEADERS AND IMPACT BREARERS}

A roadheader is a mobile, partial-face boring machine. Cutting tools are tungsten carbide picks on rotating cutterheads mounted at the end of one or more cantilevered booms. In typical use, the machine is not braced against the tunnel walls. For clrcular openings in relatively massive, strong rock, roadheaders cannot be sufficlently productive to compete with full-face equipment and plck costs are likely to be high. However, if a noncircular cross section is required or mobllization time is short, roadheader excavation may be preferred. In lower strength or less massive rock, where support installation may control the rate of advance, roadheaders may be competitive with full-face equipment.

Impact breakers are percussive machines which break rock by mechanical 1mpact. Expected low advance rates indicate that no serious consideration should be given to this type of tool, other than for trimming operations.

Research and Development

Overall, a full-face TBM is clearly recommended for most efficlent excavation of tunnels. Thus, subsequent comments on tunnel construction equipment are directed only toward full-face, TBM-based systems.

significant increases in TBM excavation rates can be achieved by implementing equipment developments and applications of emerging technologies. Areas for particular attention include cutterhead power, cutting tools, main bearings, fatigue resistance, shield design, water-jet assisted cutting, continuous monitoring, and robotics.

\section{COTTERHEAD POWER DENSITY}

Higher penetration rates result in substantial increases in cutterhead torque and power requirements. At present, the most significant factor limiting penetration rate is the amount of power which can be installed in the space avallable at the face. Although some success has been noted recently in increasing power at the face, developments and basic changes in motor and drive mechanism design are needed to increase the power density of the cutterhead.

COMTING TOOLS

For the foreseeable future, the single disc cutter is likely to be the principal cutting tool for TBM excavation. Significant advances in cutter design are possible for increased excavation efficlency. Power requirements for excavation (hp hour/ton of rock) can be substantlally reduced by incorporating high thrust cutters which permit larger spacing between kerfs and fewer cutters on 
but this figure might be reduced by incorporating instrumentation to detect problems and allow malntenance before breakdowns occur. Redundant systems, which can be automatically utilized as required, can also be incorporated into TBM system design to increase equipment avallability.

\section{ROBOTICS}

Remotely operated and robotic systems can be incorporated for varlous purposes to increase rellability and reduce the number of required personnel. The following applications for robotic systems are particularly interesting:

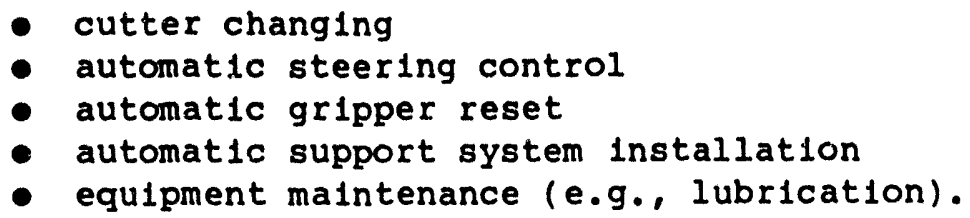

Rock Support Installation

\section{INITIAL SUPPORT}

When initial support is required to ensure stabllity of the heading, the following equipment can be used for installation:

- hydraulic rock bolt drills mounted on the TBM to install bolts within about $8 \mathrm{ft}$ of the dust shield.

- mechanical erectors to facilitate installation of steel sets and structural fabric ("weld mesh") lagging within a finger shleld about 6 ft behind the dust shield.

Structural fabric has been used in Australia and West Germany for its ability to yleld while contalning falled rock, but such fabric has not been used extensively in the United states. This technology should be considered and demonstrated prior to construction of the facilities discussed here.

Particular attention should be given to optimizing the rate of erecting steel sets within the tralling fingers.

It will be noted that shotcrete is not mentioned as a component of the initial support system. Recent experience with shotcrete applied in the vicin1ty of a TBM has resulted in considerations of equipment maintenance. The problems encountered w1th current technology suggest that application of shotcrete in close proximity to a TBM is undesirable and should be avolded.

\section{FINAL LINING}

In some rock masses, a final tunnel lining can be erected near the active heading, precluding the need for initial support installation. For example, precast-concrete segment liners can be placed Immediately behind the TBM gripper locations, and erection equipment can be provided. Alternatively, conventional cast-in-place liners with steel fiber or rebar reinforcement can be placed with collapsible or telescoping formwork.

Work has been progressing on the conceptual development of extruded tunnel lining systems both in the United States (slip-form type) and in west Germany. 
the cutterhead. Increased cutter disc 11 fe and resistance to abrasive wear are possible with the use of new alloys for disc rings and the expected development of improved single disc carbide-insert cutters. In addition, improvements in the design of center cutters are desirable to reduce high wear rates and scuffing assoclated with the tight rolling radius. Attention also should be directed toward improvements in bearing seal design to extend cutter ilfe.

\section{MAIN BEARINGS}

When TBMs are consldered for excavation of very long tunnels, the need for superior quality and more easily changed maln bearings becomes imperative. In current machines, replacement of a falled maln bearing requires a 4-week minimum shutdown. Improved conventional bearlngs, or possibly hydrostatic bear1ngs, must be developed. Furthermore, changes in the machine configuration are required to permit rapid replacement without over-excavation or pulling the machine from the face.

\section{FATIGUE RESISTANCE}

Faster cutterhead rotation rates and higher thrust produce cutterhead and machine vibrations with higher amplitude and frequency. The potential for fat1gue problems will increase, particularly when machines are used for longer drives. Structural plate alloys with increased toughness should be incorporated into cutterhead design. Attention also should be given to saddle design detalls because saddle bolts fall with increasing frequency on machines with high rotation rates.

\section{SHIELD DESIGN}

Under conditions of high in-situ stress, ground squeezing around the TBM can slow advance rates or stall progress completely, locking the machine in place. Improvements in the design of TBM shlelds are needed to facilitate operation of equipment in squeezing ground conditions.

\section{LOW PRESSURE, WATER-JET ASSISTED CUTTING}

The use of low pressure (as low as 2,000 ps1) water jets to assist disc cutting results in significantly reduced cutter forces. Force reduction is not particularly significant in softer rock where high penetrations can be realized with unassisted cutting. However, in harder rock the force reduction can be a major benef1t, allowing increased penetration rate by a machine with a given torque capacity. Water-jet assistance may be especlally useful at gage and center cutter positions where 1t may extend cutter 11fe. Pumps required to generate low water pressures are commerclally avallable and of proven rellability for long perlods of operation.

\section{CONTINUOUS EQUIPMENT MONITORING}

The advance rate of a TBM depends both on the rate of penetration and on equipment avallability. For recent, well-run projects, actual boring tine is typ1cally only about 50 percent of total shift time. Perhaps only 20 percent of the downtime is attributable to service and repalrs of TBM system components, 
The less sophisticated German design has been used in a 22.5-ft diameter softground tunnel.

Placement of a final lining is an operation that should be located 1,000 to $3,000 \mathrm{ft}$ behind the TBM tralling floor and be "decoupled" from the tunnel excavation process. Development of a viable lining system that is closecoupled to the rear of the machine is possible, but not likely to be accomplished within the next five years.

\section{Ant1c1pated Advance Rates}

W1th implementation of the suggested equipment modifications, advance rates currently achleved can be increased significantly. Assuming that horizontal and vertical muck removal systems are designed for "no-delay" haulage, that initial support requirements are minimal, and that no delay occurs in confunction with placement of arch concrete, then an estimate of TBM performance can calculated (Table 1).

TABLE 1 Potent1al Performance of a Modifled Excavation System

\section{Uniaxial Compressive \\ Strength of Rock} ks 1

5 to 10

10 to 20

20 to 30
Estimated Rate
of Penetration ft

28 to 35

25 to 28

18 to 25

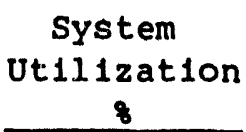

35

45

55
Average

Advance Rate

ft/day

235 to 294

270 to 302

238 to 330

An 18- to 20-ft diameter TBM w1th 2,000 hp installed power and an energy fonsumption rate of about $3 \mathrm{hp}-\mathrm{hr} / \mathrm{ton}$.

Rate of penetration limited by assumption of installed power.

The rates of penetration for the three ranges in rock strength listed in Table 1 are estimates based on boring experiments conducted at the Colorajo School of Mines. The system utilization values are estimated to include time from the start of operation with the tralling floor until completion of the tunnel. Advance rates are simflar for the clted rock strength groups, and an overall average of 250 to $300 \mathrm{ft}$ per 24-hour day is potentially achlevable. Such an achievement would present a conslderable challenge at great depths and high amblent temperatures. For tunnels at depths less than 5,000 ft, however, advance rates in this range are a reasonable goal for the 1990-1995 t1me per1od.

\section{EXCAVATION OF CROSSCUTS AND INTERSECTIONS}

\section{Types of Equipment}

Five types of mechanical excavation equipment are considered for efficlent excavation of crosscuts and trimming operations at intersections. They are roadheaders, multipurpose boring machines, mobile miners, partial-face mobile excavators, and water-jet equipment. 


\section{ROADHEADERS}

Roadheaders are machines equipped with rotary cutterheads, e1ther drum or milling type, mounted on one or more boom arms. Th1s equipment is highly flexible and good for small, intricate jobs. A roadheader unit is easily moved and can cut any cross-sectional shape. Reaction to the cutting forces is supplied by the dead welght of the equipment. Roadheaders are not usually braced against the excavation walls; some gripping mechanism would increase cutting efflclency but at loss in flexibility.

Single-pass operations can cut 6 - to 20-ft openings. Larger drifts can be excavated with shleld-mounted roadheaders or heading and bench construction techniques. Typlcal cutting tools are plcks, and utilizations of less than 30 percent are commonly achleved on jobs where support installation is required.

Currently, roadheaders are operated in rock with uniaxial compressive strength less than about 15,000 psi. If the rock is massive, the limiting uniaxial compressive strength for efficient excavation can be as low as 5,000 ps1. The disadvantages of roadheader excavation include slower advance rates, high cutting tool costs, and the tendency for heavy machines to "cut up" the 1nvert during mining. Roadheaders will be most useful for low volume, intricate shaping or trimming in rock of moderate strength.

\section{MULTIPURPOSE (FULL-FACE) BORING MACHINES}

Multipurpose borling machines (MBMs) are short, maneuverable tunnel and shaft boring equipment currently in development. The MBM, intended to be selflaunching and to be used in soft to hard rocks, includes sldewall grippers for reaction of cutter forces. Th1s equipment is remotely operated, so that personnel are not exposed to hazardous conditions or unsupported ground and ventilation requirements may be reduced.

The MBM is designed for horizontal, sloped, and vertical excavation. Muck removal equipment is required for uphill excavation where grades are up to about 60 percent ( 30 degrees). Grades greater than th1s will "self-muck" by gravity. The maximum downgrade for excavation 1 s about 27 percent (15 degrees), a limitation imposed by the machine conveyor in current use. Abrupt grade changes can be accomplished with a relatively small required radius, about $80 \mathrm{ft}$ for 6 - to $8-\mathrm{ft}$ dlameter headings. The existing design is for machines in this diameter range only. If the size were to be increased, some flexibility would be lost.

\section{PARTIAL-FACE MOBILE EXCAVATORS}

Partial-face mobile excavators are machines which use disc cutters on a partial-face cutterhead. The cutterhead rotates on an axis and can be moved transversely to cut a rectangular opening. Anchoring is provided by side and/ or crown and 1nvert hydraulic grippers. One type of partial-face excavator in current use is the mobile miner, which was developed to excavate a rectangular opening $12 \mathrm{ft}$ high by $20 \mathrm{ft}$ wide. Other units are designed to cut openings from $7 \mathrm{ft}$ high by $10 \mathrm{ft}$ wide to $14 \mathrm{ft}$ high by $22 \mathrm{ft}$ wide. Two-pass operations are possible for higher openings.

The mobile miner leaves a flat invert and can excavate efficlently both tunnels and slopes to 36-percent ( 20 degrees) grade. This equipment is very flexible and well sulted to elther hard or soft rock. Partlal-face equipment 
will be most effective for side entries with lengths too short to fustify mobllization of full-face units.

WATER JETS

Water fets are employed frequently for operations in uraniferous sandstone, e.g., drilling roof bolt holes. The equipment performs best in porous or soft rock, although high-pressure water fets have been applied successfully for slotting granite dimension stone. Minimal amounts of water are required at high pressures, and the support equipment 1 s compact and easily moved. Power requirements are high, so that water jets alone cannot be considered compet1tive with other equipment for large volume excavation.

The use of water-jet assisted bits for drilling and cutting is a proven approach to excavating rock and will facilitate excavation of intricately shaped openings in areas where damage to the surrounding rock must be minimal. Excavation with water-jet assisted drills and slotting equipment generally results in bit life that is many times greater than that for conventional tools.

Research and Development

To 1mprove the operating efficiency of crosscut excavation equipment, attention should be devoted to implementing the following developments and modifications:

- Water-jet assisted roadheaders for softer rock.

- Bracing mechanisms for roadheaders and water jets to provide increased performance in harder rock.

- Hard-rock roadheader with disc cutters and, perhaps, water jets.

- Increased flexibility in partial- and full-face boring equipment.

- Partial-face mobile excavators for larger section, short-length tunnels.

\section{ACCESS SHAFT EXCAVATION}

Types of Equipment

Varlous types of mechanical equipment can be considered for use in excavating the 3,000- to 8,000-ft deep, 20- to 25-ft finished-dlameter shafts to be used for construction access. In the following discussion, the terms "drilling" and "borl.ng" are not interchangeable. "Drilling" refers to equipment with the power supply located remotely at a derrick and transferred to the face via a drill string or plpe. "Boring" indicates equipment with a power supply downhole, part of the cutting equipment.

\section{BLIND DOWNHOLE DRILLING}

Large-diameter drilling may be a possible technique for excavating access shafts. Using a reverse circulation, a1r lift method of muck removal, shafts have been drilled in a single pass at 10-ft diameter and 8,000-ft depth in Amch1tka, Alaska, and at 14-ft dlameter and 2,460-ft depth in Western Austra11a. Multiple-pass shafts have been drilled at 25-ft diameter and 1,680-ft 
depth in Holland (1954-1959). These multiple-pass shafts were completed in 40 to 43 months.

Drilling shafts is inherently safer than conventional sinking because no personnel enter the shaft until it is fully lined. Moreover, drilling can be the only practical construction option in some geological conditions, 1.e., very soft ground or very wet conditions. The water (or mud) in the shaft supports the walls and stems the water 1nflow by virtue of 1 ts hydrostatic head. Formulating the mud to match the chemistry and requirements of the rock is an established science.

At least two rigs have been bullt with power (to 0.5 million ft-lbs torque and 2.0 million lbs $11 \mathrm{ft}$ ) sufficlent to drill large holes at an economical rate. However, the practicality of bullding larger and larger rigs is questionable. A disadvantage of the drilling system is the requirement that all power to the rock face must be transmitted through the drill string. The cost of a few thousand feet of large-diameter drill plpe will exceed the price of the arill rig.

One fundamental ilmitation of the blind shaft drilling technique is the accuracy of the shaft. In general, a shaft proceeds in an ever expanding spiral and deviation control is totally passive. Shaft tolerances are especlally critical if the ultimate use of the shaft involves high speed holsting. Malntalning true verticality within 0.25 degrees is a function of geology, equipment, crew talent, and sometimes luck.

In summary, drilling may be a viable option at diameters of 12 to $16 \mathrm{ft}$ and depths of 3,000 to 5,000 ft. At slzes and depths beyond these, blind drilling probably reaches 1 ts economical and feasible limits.

\section{BLIND DOWNHOLE BORING}

The use of a downhole boring machine--similar to a TBM operated vertically--1s, in theory, an option for conventional shaft construction. Th1s manned system uses all the established conventional techniques except that the drilling and blasting operation is replaced with a mechanical full-face or partial-face rock cutting head. Muck holsting may be accomplished by conventional skips.

Shaft boring with a manned downhole machine was f1rst attempted in 1969 by zen1-McKinney-W1lliams. In 1980, a 24-ft dlameter 670-ft deep shaft was bored and lined in a program sponsored by the U.S. Bureau of Mines. This program involved a full-face shaft borer, followed by a work deck or galloway. A Jump form was used to install concrete lining. The shaft boring machine was laser guided and never deviated from true vertical more than $0.75 \mathrm{in}$. Although the boring machine built a structurally acceptable shaft, progress was insufficlent for economic operation. The major problem related to plcking the muck off the face and transporting it vertically to a skip loading station.

The f1rst known partial-face machine was bullt (c1rca 1965) in Russia, but little information is avallable about its performance. It was allegedly successful in sinking a 21-ft dlameter shaft. A partial-face shaft sinking system capable of 20- to 24-ft diameters has been designed and built by RobbinsRedpath but not utilized as yet. An advantage of a partial-face machine 1s that access to the face and the head is accomplished more easily than with a full-face unit. A disadvantage is that the partial-face configuration limits the power which can be applied to the rock so that the excavation rate may be less than with full-face equipment. 
A shaft boring system has the potential to meet the requirements for shafts in large diameters up to $8,000 \mathrm{ft}$ deep, w1th accuracy acceptable for high speed holsting. The capital cost of such a system is less than an equivalent drilling system for shafts larger than about $20 \mathrm{ft}$ in diameter and 1,500 ft deep. All the techniques developed for conventional sinking--such as temporary support, grouting, lining, panning, pumping, and freezing--may be used to control the rock and water inflow. As in conventional sinking, depth limits are largely dictated by holsting cable capacity.

\section{REAMING}

The use of reaming equipment involves drilling a pllot hole and enlarging the hole to finished diameter in one or more additional passes. Both upward and downward reaming are common techniques. In elther case, however, rock removal 1s by gravity and access to the bottom of the shaft is required. The technique is not applicable to the initial access shaft but is generally an economical option for additional shafts once underground works have been extended.

For shafts at smaller dlameters (e.g., 12-ft diameter to 3,000 ft deep) or shallower depths (e.g., 1,000 ft deep at 20-ft dlameter), ralse drilling 1s commonly used. Where applicable, ralse drilling is by far the least expensive method of shaft excavation. However, as with other drilling methods, all the power to the cutting head is transmitted via drill plpe, which limits both the capability and economic feasibility of ralse drilling.

Because all ralse reaming techniques follow a pllot hole, tolerances of the final shaft are dictated by the accuracy of the pilot hole. Methods to control pilot hole accuracy, as well as the survey tools, are slow and expensive to use and their accuracy levels are not far beyond the required shaft tolerances.

Recently, in South Africa, a sequential reamer was used for larger d1ameter (1.e., 20-ft) shafts. The ralse-type reamer cuts in sequence, f1rst an intermediate diameter and then the final diameter. Although the raise head is full dlameter, it is constructed having two independently rotating components. This technique limits the power transmission requirements of the drill string by cutting only a partial face at a given time. The switching between the two components is done automatically.

A down reaming machine, sometimes referred to as a " $V$ " mole, has been used for larger shafts. Like a blind shaft borer, this unit is manned, fo ws a laser beam, and employs conventional techniques for ground and water control. The principal difference is that rock cuttings are swept down a previously excavated shaft, generally in the 6- to 8-ft diameter range. Because the vmole power system is located 1 -hole at the face, much greater power can be applied to the rock. As a result, this type of machine has been used successfully to excavate shafts in hard (to 40,000 psi compressive strength) rock to a dlameter of $28 \mathrm{ft}$. In deeper and larger diameter shafts, capital costs for the equipment required are less than for blind drilling. The extensive power capability of a $V$-mole has been demonstrated in enlarging a shaft from 8 ft to $24 \mathrm{ft}$ in diameter at a rate exceeding $100 \mathrm{ft}$ per day.

The down reaming method has the potential to meet all shaft excavation requirements to depths of $8,000 \mathrm{ft}$, provided that access at the bottom to handj.e muck has already been established. 
An 1mpactor shaft sinker has been constructed and tested in the United States, but in one commercial use to date the equipment was not successful in excavating homogeneous, massive rock. Expected advance rates for the 1mpactor are not competitive with rates possible using other types of equipment.

\section{Excavation Methods}

Three methods are suggested as options for sinking deep, large-dlameter, access shafts. They are pllot hole drillinj and reaming, blind boring, and conventional drill-and-blast.

\section{COMBINATION BLIND DRILLING AND REAMING}

This method, which is used for initial opening of a mine or other underground workings, is a combination of blind drilling and raise reaming or down reaming. A 6- to 8-ft finished-dlameter shaft is blind drilled to final depth and cased with a hydrostatic lining. A smaller diameter unlined pilot hole is also drilled to depth, and a connecting drift is excavated between the two at the working level. Then the pllot hole is enlarged to the required shaft dlameter. Muck from the subsequent reaming operation is removed through the blind drilled and Iined shaft, which is fitted with a muck holsting system. Several equipment options are avallable for enlarging the pllot hole and selection depends on shaft depth and finished diameter:

\footnotetext{
- single pass reaming with a raise arill

- multiple pass reaming with a raise drill

- ralse reaming with a sequential reamer

- down reaming, as with a V-mole (requires elther an intermediate ralse excavation to about 6-ft diameter or drilling the original pilot hole to at least 2-ft diameter).
}

Current methods of pilot-hole drilling are expensive and slow, with typical advance rates not exceeding $5 \mathrm{ft}$ per hour. The penetration rate is deliberately kept low to increase accuracy. The accuracy of the pilot hole is important because the final shaft may be fitted with a high speed hoist. Techniques currently used for increasing drilling accuracy create "dog legs" from intermediate deviations and corrections. These "dog legs" also can cause an out-of-specification haulage shaft. Compensation for errors of a few feet in pilot hole alignment can be accomplished using a $v$-mole type of unit.

At a depth of $3,000 \mathrm{ft}$, all of the equipment options noted above are feasible. Completing the access shaft with a single pass or sequential reamer extends the state of the art, but the method is within current technological capability.

At 5,000-ft depths, blind drilling of the initial 6- to 8-ft shaft in hard rock is technically marginal. The total welght of the drill string, bit, and welghts for pendulum and cutter force exceeds the capacity of any current rig. In addition, accuracy requirements for a drilled hole are difficult, if not impossible, to meet with current technology.

At a depth of $8,000 \mathrm{ft}$, the procedure of blind drilling the muck holsting shaft and pllot hole, with subsequent enlargement of the pllot hole to full 
coistruction size, is not a practical solution in the near term. Particular problems include drill string and rig avallability for the initial blind shaft, pllot hole accuracy, and the effects of squeezing or spaling ground on the preliminary drill, pllot hole, and intermediate or final reaming.

\section{BLIND BORING}

Blind shaft boring to full diameter is technically possible, but improvement in performance is required for economic feasibility. The potential exists for favorable advance rates (at least twice as fast as for conventional excavation) because blind shaft borers can apply more power onto the face than drilling methods. Adequate shaft diameters are possible w1th 1ncreased power, and the equipment allows more precise control of deviation than drilling techniques.

A manned shaft boring machine is approprlate for all rock strengths consldered and for shaft depths up to $8,000 \mathrm{ft}$. Any sultable $11 \mathrm{ning}$ system can be employed. Visual inspection and testing of the rock is possible during sinking, and developed techniques for controlling instability or groundwater inflow problems can be applled.

\section{CONVENTIONAL}

Dr1ll-and-blast techniques must be considered an option for access shaft excavation and slashing for small-diameter shaft enlargement. Drill-and-blast shafts can be completed very accurately in rock of all strengths considered, and continuous geological inspection is possible so that ground problems can be handled by standard techniques.

single-pass sinking of full size openings by conventional methods is the only demonstrated means of constructing large-dlameter shafts to depths as great as $8,000 \mathrm{ft}$. The disadvantages of this method include : wer advance rates (no more than $10 \mathrm{ft}$ per day can be expected), more disturbed rock mass than with mechanical equipment, labor-1ntensive construction, and extremely hazardous working conditions.

Research and Development

Shaft sinking by blind shaft boring equipment holds the potential for the shortest schedule and lowest cost of all the melhods consldered here. Improvements in performance are possible, particularly if additional attention is given to developments in mechanical or pneumatic and vacuum mucking systems.

For drilling and reaming operations, attention should be given to developing the capability for increased accuracy in pilot-hole drilling.

In drilling operations, carblde insert cutters are commonly used. The development of longer-life carbide insert cutters will help to reduce trip time required for cutter replacement. The potential use of new alloy disc cutters should also be investigated for downhole drilling operations. In addition, attention should be devoted to improving cutter bearing seals and developing longer-life bearlings. This is particularly important in view of the higher temperatures, debilitating groundwater, and abrasive wear to be expected under adverse conditions in a deep shaft.

For blind shaft boring, a potential future technology involves the development of a submerged boring machine capable not only of applying high horsepower onto the face but also of utllizing an alr lift or pumped slurry method 
of muck removal. A submerged machine could be of great benefit where the hydrostatic pressure of a mud-filled hole is required for shaft stability. However, a major disadvantage would be the need to remove the machine for malntenance and cutter changes. The feasibility of this type of unit may be paced by the development of highly rellable components and longer-life cutters, capable of withstanding heads in excess of 5,000 ft for nore than a few hours of operation.

\section{INTERNAL SHAFT EXCAVATION}

Types of Equipment

Internal shafts within a deep fac1lity may be temporary or permanent and may be open connections between levels or blind shafts, as the facility design requires. Four types of mechanical equipment can be recommended: raise drills, blind ralse drills, blind shaft drills, and multipurpose boring machines.

\section{RAISE DRILLS}

The ralse drilling operation involves single-pass reaming of pilot holes and requires access to the top and bottom of the shaft. Ralse drills have been used for excavation of hard and soft rock, with the largest diameter shafts completed in softer rock.

The equipment has been demonstrated in 20-ft diameter shafts up to $670 \mathrm{ft}$ deep and in 12-ft diameter shafts up to 3,000-ft deep. Using a sequential reamer, 20-ft dlameter shafts have been completed to depths greater than 1,000 ft in hard rock. The only limitations to the raise drilling technique are unstable ground (from low strength or exceptional depth) and accuracy as controlled by the pllot-hole drilling.

By a wide margin, raise drills offer the fastest, most economical, and most demonstrated method of construction. Ralse drilling with directionally drilled pilot holes will be the optimum method of internal shaft excavation in good ground conditions.

BLIND RAISE (BOX HOLE) DRILLS

Box hole drills are commonly used for the construction of ore passes in stope mines. A pllot hole is not required, and access is necessary only to the bottom of the shaft. Current technology includes equipment with in-the-hole drives and non-rotating drill string, derrick-mounted drives and rotating drill strings, and large-diameter units propelled by plpe-jacking methods. Demonstrated capability of this equipment includes 15-ft diameter shafts to 150-ft lengths and 5-ft dlameter shafts to 300-ft lengths. The box hole technique 1 s slower and more labor-1ntensive than ralse drilling. Typlcal drilling accuracy is about one percent.

\section{BLIND SHAFT DRILIS}

The blind shaft drilling operation involves downward drilling without a pllot hole. Access is required only to the top of the shaft; therefore, blind shaft drills can be considered where bottom access is not practical. Although an 
underground $\mathrm{rig}$ does not exist, requirements for development are not extensive. Such a rig would be very similar to a ralse drill.

\section{MULTIPURPOSE (FULL-FACE) BORING MACHINE}

The multipurpose boring machine (MBM) is a concept under development. As concelved, the MBM is a short, maneuverable machine, similar to a remotely controlled TBM. One such unit is in existence and has undergone laboratory testing. The device has the potentlal to follow a compound curve, perhaps starting a drift horizontally and then turning vertically to continue excavation. The existing unit--5.7 ft in diameter and equipped with 200 hp of power and variable cutterhead speed--1s designed to excavate a 1,000-ft long incline or raise.

Research and Development

To 1mprove the performance of Internal shaft excavation equipment, attention should be directed to the following areas:

- Development of an underground blind shaft drill.

- Continued development of the multipurpose boring machine concept.

MUCK HANDLING SYSTEM

Transport in Tunnels

At the heading, muck buckets on the TBM cutterhead scrape muck from the invert and deliver it to a chute at the top of the cutterhead support structure. The chute discharges muck onto a short conveyor which transfers material to the rear of the TBM. The TBM conveyor discharges muck onto a second (tralling) conveyor which is bullt into a tralling platform and towed behind the TBM.

Movement (haulage) of muck through the tunnel is typlcally accomplished by one of four types of systems: rail, conveyor, wheeled, or pipeline.

RAIL SYSTEM

A TBM tralling platform is generally fitted with double-track rall and a switch at the end of the platform near the junction w1th the maln tunnel track. Ra1lmounted muck cars are filled by one of two methods:

- The discharge point of the tralling conveyor is at a fixed location, to one slde of the tralling platform for dual-track platforms. Empty muck cars are transferred from the incoming to the outgolng track with a car-passer, and the cars are positioned under the end of the conveyor for filling. This system can provide continuous muck removal, assuming that a supply of empty cars can be maintained at the heading.

- The tralling conveyor is at least as long as an assembled train and is centrally located with respect to the tunnel walls. Trains remain stationary during muck car filling. The conveyor is fitted with a movable deflector (tripper) which is positioned at locations along the conveyor and can direct muck into cars on one side of the tunnel. After 
a train is loaded, muck transfer is halted while the deflector is returned to 1ts starting position at the leading end of the trailing floor for use in loading a train on the opposite slde of the tunnel. This system also can provide continuous mucking but generally requires a large trailing platform.

Tunnel haulage is typlcally on 24 - to $36-1$. gage rail, with wider gages for larger tunnel dlameters. Diesel locomotives are used and, if space is avallable, tunnel rall may be double tracked. At the mucking shaft, muck cars are emptled with a rotary dump, and muck is transferred into a holst surge bin.

All facets of the described rall system are state of the art. If grades are relatively flat (less than one percent), this system will provide no-delay haulage for a 5-mile long heading. For unfavorable grades and/or longer hauls, additional ventilation or trolley electric locomotives may be required. The limiting grade for unassisted rall haulage 1 s about three percent (1.7 degrees).

\section{CONVEYOR SYSTEM}

Belt conveyors have been used for tunnel haulage on a few TBM projects, but delays assoclated with belt extension, repalr, and maintenance have been significantly greater than for rall systems. In addition, conveyors only haul in one direction. Thus, alternate systems for material and personnel transport must be provided.

A conveyor system of some varlety (e.g., pocket, bucket, cover belt) can be used for material transport on any slope, but conventional belt conveyors can be used only for grades up to about 30 to 35 percent (18 to 20 degrees). Heat dissipation and ventilation requirements will be lower for conveyor than for rall systems.

Conveyor systems have the potential to accommodate the increased advance rates anticipated and may be the only equipment capable of maintaining high capac1ty, uninterrupted service. Recent developments in belt technology and techniques for speedy repalr have increased the rellability of conveyor systems and reduced the occurrence of extensive downtime for belt replacement. In many mining and manufacturing operations, belt conveyors have been demonstrated to. be the most economical cholce for long-distance haulage.

\section{WHEELED SYSTEM}

Load-haul-dump (LHD) vehicles will only be useful for very short hauls and for short-term operations such as mobilization. Low profile dump trucks can provide faster, higher capacity service than $L$ HD vehicles, and may be economical for muck haulage in short- to intermediate-length headings. Wheeled systems may be diesel, electric, or battery powered.

Wheeled systems may be preferred where flexib1lity and maneuverability in tight areas are required, and vehicles can be operated on grades up to about 17 to 20 percent ( 10 to 11 degrees). However, requirements for flatter inverts and larger openings (1.e., greater than $15 \mathrm{ft}$ ) are more stringent than for rall or conveyor haulage. 
PIPELINE SYSTEM

Slurry and pneumatic plpelines have been used for bulk materlal transport. Haulage rates as $h 1 \mathrm{gh}$ as 150 tons per hour of rock have been achleved in special applications. Although capable of continuous, uniform, high-capacity transportation in both horlzontal and vertical directions, these systems are not given further attention because the following factors reduce their potent1al:

- IImitations on muck particle sizes

- abrastve wear of plpe, pumps, and valves

- space required near the heading for required plant components

- large power requirements.

Transport in Crosscuts, Intersections, Ramps, and Slopes

For crosscuts and intersections, it is expected that LHD or low-profile trucks could be used for short distance transfer to passing haulage. Loading of the hauling vehicles would be accomplished by mucking shovels or front-end loaders. Extendable conveyors could be used in slde passages. However, wheeled vehicles are likely to be preferred for mobllity, flexibility, and ease of maintenance.

For ramps and slopes, unassisted rall haulage can be used to handle muck only at grades up to about three percent; conveyor haulage can be used for grades up to about 35 percent (20 degrees). For steeper grades, cars or buckets on track or cable guides can be used if a winch assembly is added to the rear of the boring machine. For dry conditions, upslope excavations with grades greater than about 85 to 100 percent ( 40 to 45 degrees) w1ll "self-muck" by grav1ty. W1th water present, the grade for "self-mucking" is reduced to about 35 percent ( 20 degrees).

\section{Transport in Shafts}

Vertical movement of muck from the botton of a deep construction shaft can be accomplished by the following methods: conventional holst, conveyor, pneumatic, and hydraulic.

For conventional holsting, avallable equiprient includes mechanical friction and drum holsts. Th1s equipment is the only type in common use for vert1cal movement of material from depths as great as $8,000 \mathrm{ft}$.

Conveyor systems consisting of bucket elevators and tray-lift conveyors have been used for vertical muck disposal. However, these systems have not been applied in shafts of the depths considered here.

Pneumatic and hydraulic systems have been used for continuous-lift vert1cal mucking, but not in shafts of the depths considered here. The limitations of this method prevlously noted for tunnels apply in this case as well.

Research and Development

The most likely methods for horizontal muck transport in long tunnel headings are rail and conveyor haulage. For vertical muck transport in shafts, conventional holsting equipment $1 \mathrm{~s} 11 \mathrm{kely}$ to be preferred at this time. Increases in haulage capacity and system rellability can be achleved by implementing 
equipment developments and extensions of existing technologies, as follows:

- Ra1l systems that incorporate advances in automation for remote operation, car switching, and dumping would serve adequately for the Increased advance rates anticlpated.

- Redundant holsting systems should be considered to allow continuous, rellable mucking for shafts. One system suld continue to operate durIng maintenance (often time consuming) or repalrs to the other.

- The potential for use of a vertical conveyor (cover belt) should be invest1gated for holsting muck up deep shafts.

In view of the fact that perhaps 20 to 25 percent of all shift time is typically associated with haulage delays and repalrs to tralling and backup system components, continuous equipment monitoring techniques should be incorporated to minimize downtime. Redundant systems, which can be automatically utilized as required, should be provided. Remotely operated and robotic systems can be developed for regular maintenance to increase system rellability.

\section{SUMMARY}

Mechanical excavation systems are feasible for the construction of deepunderground facilities and the basic technological capabilities exist within the construction industry. Of all the components of a deep facility that are considered here, greatest concern is focused on the excavation of deep, external shafts.

Full-face tunnel borlng machines are the preferred method of tunnel excavation. W1th no-delay haulage and support installation, and incorporation of suggested modifications, an advance rate of 250 to $300 \mathrm{ft}$ per 24-hour day is potentlally achievable.

For tunnels at low grade, rall haulage systems should be adequate for muck haulage at the anticipated advance rates. For grades greater than 2 to 3 percent, conveyor haulage will be the preferred method.

Adequate initial support can be installed very near the face on a no-delay basis, provlded that the facility is sited in high quality rock. Construction of a final lining san be a decoupled operation, located well behind the tralling floor. A viable system for final lining installation in the immediate vicinity of the TBM is not likely to be developed within the time period under consideration here.

For excavation of crosscuts and short tunnels, recently developed equipment such as the multipurpose boring machine and the moblle miner will be of greatest use. For trimming and shaping operations, roadheaders and water-jet drills will be most effective.

For access shafts, blind shaft boring holds the potential as the quickest, lowest cost sinking method. If attention is given to the development of an 1mproved mucking system, blind shaft boring will be the preferred method. For internal shafts, excavation w1th raise drill enlargement of directionally drilled pilot holes will be the optimum method. 
Association Internationale des Travaux on Souterrain International Tunnelling Association

Compte Fendu de l'Assemblée Générale

Florence

B t 11 JUIN $19 a$

Repart of the General Assembly

Florence

JUNE $B$ and 11, 1080 
The 1986 General Assembly of the ITA Member Nations was held in FLORENCE (Italy) on June 8 \& 11, 1986, under the presidency of J.K. LEMLEY (USA) assisted by the ITA Executive Members and the ITA Secretary C. BERENGUIER.

OFFICIAL DELEGATES OF THE MEMBER NATIONS REPRESENTED

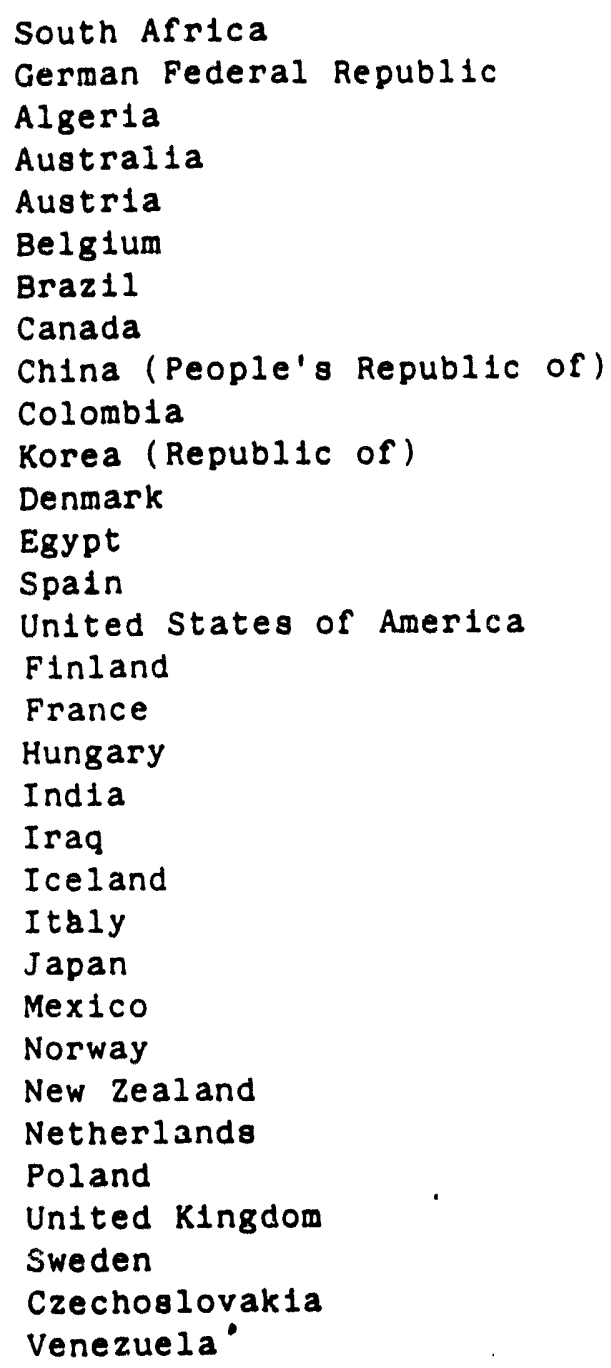

\section{INTERNATIONAL ASSOCIATIONS REPRESENTED}

Permanent International Association of Road Congresses A.M. MUIR WOOD International Soclety of Soll Mechanics and Foundation Engineering

M. DOLCETTA 


\section{Sunday June 8}

1. Opening addrese

2. Approval of the agenda

3. Approval of the minutes of the 1985 General Assembly

4. Examination of candidatures of new members 4.1. Members Nations 4.2. Affiliates

5. Report of activity of new member nations

6. Contributions from the International Associations

7. Report of activity of the Executive Counc1l 7.1. Operation of the Executive Counc11

7.2. Developuent of contacts

7.3. Operation of the working groups

7.4. ITA Journal

7.5. Relations with the United Nations

8. Financial affairs

8.1. 1985 Report and approval

8.2. 1986 Report and approval

8.3. Approval of the proposed 1987 budget

9. Future General Assemblies

9.1. A:stralla 1987

9.2. Spain 1988

9.3. 1989 Assembly

9.4. Further General Assemblies

10. Other brief reports and discussion

11. Preliminary discusaion about the election of the Executive Members

- 12. Various announcernents

\section{Wednesday June 11}

13. Election of the President and two Vice-Presidents

14. Working groups - Reports and future activities

15. Report on the Open Session

16. H.C. FISCHER's intervention

17. Appointment of the Secretary General

18. Appointment of the Nomination Committee

$19 . .$. Other business

20. Closing address 
GENERAL ASSEMBLY ON SUNDAY JUNE 8 (10:00 - 12:15)

1. OPENING ADDRESSES

a) President LEMLEY welcomed the delegates from the 25 ITA Member Nations attending or represented, and presented the apologies from Denmark and New zealand. He thanked the Italian Committee 'Gallerie', a member of the ITA, for the preparation of the 12 th ITA Annual Meeting.

The President made a brief survey of the activities of the Association since the Prague Meeting; he particularly emphasized the ITA participation in several international meetings (Hanover - Tokyo), the efforts to the United Nations to obtain the NGO status, and the necessity to increase the number of ITA members; he noticed with satisfaction the significant development of Affiliate Members. The President gave a brief description of the new arrangements concluded by the ITA to publish the works (contract with Pergamon Press) and support the activities of the working groups (contract with STUVA).

b) B. PIGORINI, Chairman of the Congress and ITA Executive Member, thanked the TTA for the support provided for the preparation of the Congress, for both technical sessions and open session and the attendance of numerous foreign delegates.

2. APPROVAL OF THE AGENDA

The President recalled the agenda, which was approved witnout comment.

3. APPROVAL OF THE MINUTES OF THE 1985 GENERAL ASSEMBLY

The minutes of the 1985 General Assembly were approved without modification.

\section{EXAMINATION OF CINDIDATURES OF NEW MEMBERS}

\subsection{Member Nations}

No countrf applied for membership since the last General Assembly. The list of the 33 Member Nations of the Association remains unchanged since 1985. 


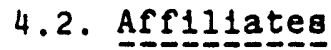

According to the decision reached in 1983 by the Member Nations when creating the Affiliates, the Secretary presented the list of 'Corporate' and 'Individual' Affiliates applying for membership.

- Corporate Affiliates :

34. KAJIMA CORPORATION

JAPAN

35. SINOTECH ENG. CONSULTANTS TAIWAN

36. THE ROBBINS COMPANY USA

37. AL JOHNSON CONSTRUCTION USA

38. SOGELERG INGENIERIE

39. UNDERGROUND SPACE CENTER

FRANCE

40. LOVAT TUNNEL EQUIPMENT

USA

41. CHINA ENG. CONSULTANTS

CANADA

42. RET-SER ENG. AGENCY

43. FRONTIER-KEMPER CONSTRUCTORS

TAIWAN

TAIWAN

44. ENEL-CRIS

USA

ITALY

- Individual Affiliates :

29. D. HAMPTON

USA

30. F.C. PIERCE

USA

31. A.A. MATHEWS

USA

32. I. KITAMURA

JAPAN

33. B.P. BOISEN

USA

34. S.F. TSOI

35. K. TONODA

HONG KONG

36. G.E. NOBLE

USA

37'. R.J. ROBBINS

USA

38. A.H. MERRITT

USA

39. E.R. ANDERSON

USA

U.K.

40. E.F. CASEY

USA

41. H.D. PASCHEN

USA

42. E.M. ZERR

USA

43. C. BAGNOLI

ITALY

44. J.S. REDPATH

CANADA

45. M.G. MELHEM

LIBANON

46. C. BRAY

ITALY

47. A. DE'DONATI

ITALY

The delegates of the concerned Member Nations and the General Assembly accepted these candidates.

Thus the number of Affiliates climbed to $89: 42$ Corporate Affiliates and 47 Individual Affiliates.

The Assembly noticed with satisfaction the confirmed success of the new category of members, especially greeted the particlpation of numerous US members (34), and gave particular thanks to President LEMLEY. 
A part of the objectives laid when creating the new category of members could therefore be reached already this year by establishing a Technical Support Institute for two working groups (see 7.3); these efforts have to be pursued and increased to assist the other working groups and set up a full-time secretariat.

5. REPORT OF ACTIVITY OF NEW MEMBER NATIONS as a reminder

6. CONTRIBUTIONS FROM INTERNATIONAL ASSOCIATIONS

a) Mr. DOLCETTA, representing the International Society for Soil Mechanics and Foundation Engineering, transmitted the thanks of President BROMS to the ITA for the invitation to attend the works and Congress that deal with topics the ISRM is most interested $1 \mathrm{n}$.

b) Sir Alan MUIR WOOD, representing the Permanent International Association of Road Congresses as Chairman of the Committee on Road Tunnels, pointed out that the next PIARC Congress will occur in Brussels from September 13-19, 1987; the Committee on Road Tunnels will produce a report devoted to plants, traffic investigations and operation; a special session will also be held on 'The Role of tunnels in Urban Environment'. Sir Alan also noticed that PIARC and ITA have numerous common members, and mentioned the coordinated works with two ITA working groups - Subsurface Planning and Cost-Benefits.

c) The International Society of Rock Mechanics and the International Road Federation could not be represented, however their Chairmen have sent greeting messages to the ITA.

\section{REPORT OF ACTIVITY OF THE EXECUTIVE COUNCIL}

\subsection{Operation of the Executive Council}

The Executive Council met successively in Prague after the 1985 General Assemb 2y, Hanover in November 1985, and Japan in March 1986.

During the past year the Executive Council has pursued the traditional activities - development of contacts and affiliates, operation of the working groups, ITA Journal, preparation of the General Assemblies...; during the year they essentially made efforts to develop the Affiliates 
(number Increased from 59 to 89 ), to operate the working groups (contract concluded with STUVA - see 1tem 7.3) and the Journal (new contract concluded with PERGAMON - see item 7.4).

The Executive Members also took a great part in the successful development of the Symposium on Undersea Tunnels organized by the Japanese Committee in Tokyo in March 1986 (see item 10).

\subsection{Development of contacts}

a) The Executive Council has cleared the question of contacts by sending a letter in December to every contact of long standing requesting to confirm interest in the ITA works; the survey allowed to set up a new list of contacts : Saudi Arabia, Argentina, Costa Rica, Cuba, Ecuador, Lybia, Marocco, Oman, Peru, USSR, and the Asian Institute of Technology.

b) The Executive Council is requesting the assistance of all participants :

- to favour the creation of a national group on tunnelling in the aforementioned countries;

- to renew contacts with representatives from the other countries, especially : East Germany, Bolivia, Chile, Israel, Paraguay, Philipines, Uruguay, Bulgaria, and Yugoslavia, which did not maintain contact with ITA.

\subsection{Operation of the working groups}

a). The Executive Council has noted the difficulties encountered by the working groups, especially 'Standardization' and 'Catalogue'; they also noted that the group 'Selsmic Effects' has completed works, and the request for changing the animateur of the group 'Contractuai Sharing of Risk'.

b) The Executive Council wished to assist those groups the activity of which seems to need an efficient support, by using the financial reserve made to this purpose; a contract has just been signed with STUVA (Federal Germany) to assist for two years two working groups selected in agreement wth the animateurs; the two groups are 'Health and Safety in works' and 'Maintenance and Repair of Underground Structures'.

c) In the future the Executive Council would wish to assigt in the same way other working groups as the working groups will develop and according to the avallable financial means. 
7.4. ITA Journal

a) The Secretary General stated that, after the discussions in 1984, a new contract was signed in 1985 with Pergamon Press based on closer relations between the ITA Journal and the review Underground Space, to create a new Journal 'Tunnelling and Underground Space Technology'.

Th new 5-year contract with Pergamon will allow the ITA Executive Council, working group animateurs and representatives from the member nations to have available a right to publish in the new Journal the formal news of the Association, reports of working groups and any announcement the ITA would desire to publish; the new Journal, with a quaterly publication chargeable to Pergamon, is therefore supported by the ITA with the assistance of the Underground Space Center of the University of Minnesota.

b) E. BROCH pointed out that the ITA members will profit by a discount rate : $30 \%$ of the normal rate fixed at US $\$ 150$ for the first 100 copies, $20 \%$ for the next $150,15 \%$ for the next 150 ; beyond this number (above $400)$ the rate w111 be negociated with the Publisher.

E. BROCH also stated that Vol.1 No.1 was avallable in Florence as 24-page coples; the final 1ssue would be avallable in a few weeks. Lastly he recalled that the member nations were invited to appoint a national correspondent to act as intermediary between the Journal authorities and the ITA Secretariat in charge with supervising the evolution.

President LEMLEY pointed out how it is important for the Association to have a proper distribution means for its works, and thezefore the necessity for the member nations to provide a maximal assistance to the development of the Journal.

\subsection{Relations with the United Nations}

President LEMLEY stated that a new file on the ITA had just been sent to the UN in view of the next meeting of NGO Committee planned for March 87. The ITA will attend this meeting to support and justify the application.

The President requested the member nations represented in the NGO Committee to intervene to their representativesto explain the position of the ITA. 


\section{FINANCIAL AFFAIRS}

\subsection{Report (Enc1.1)}

The Secretary General presented and commented the report on the final 1985 situation sent to the members with the invitation to the General Assembly; he also reported on the evolution of the Association's assets.

The President thanked the Secretary General and the Secretariat for the book-keeping, and rendered homage to France for the administrative and financial support to the secretariat.

The President stated that the rate of subscription for the member nations had remained constant for many years thanks to the increased number of Affiliates.

The General Assembly accepted unanimously the presented accounts.

\subsection{Report (Encl.1)}

The Secretary General presented the revised 1986 draft budget sent to the members with the invitation to the General Assembly; the amendments essentially concern the subscription rate for Affiliate Members, travel expenses, and the creation of the Technical support Institute.

The General Assembly unanimously approved the revised 1986 draft budget.

\subsection{7 draft budget (Enc1.1)}

The Secretary General presented and commented the 1987 draft budget sent to the members with the invitation to the General Assembly.

The General Assembly approved unanimously the presented draft budget.

\section{FUTURE GENERAL ASSEMBLIES}

\subsection{Australia 1987}

$J$. WHITEHEAD provided some detalls on the state of preparation of the 1987 General Assembly to be held in REGENT HOTEL in MELBOURNE at the occasion of the 6th Australian Conference on Tunneliling devoted to 'BORE OR BLAST'; the events w11l occur from March 23-28, 1987. J. WHITEHEAD presented the Congress brochure providing detalls on technical and touristic visits and 
the planned exhibition; he also gave a survey on the present development of underground works in Australia.

\subsection{Spain 1988}

Mr. SERRANO provided some detalls on the state of preparation of the 1988 General Assembly to be held in MADRID in June 88 at the occasion of the the International Congress devoted to 'Tunnels and Water'; a full-time secretariat has been set up to prepare the Congress; the first circular would be sent in a few weeks.

\subsection{Assemb1y}

a) The President stated that the Executive Council had received four formal invitations : BRAZIL, CANADA, HUNGARY and MEXICO; after a discussion with the candidates and considering the various factors to be taken into account the Executive Council proposed to select the Canadian candidature.

The General Assembly accepted unanimously the Executive Council's proposition.

b) The Canadian delegates R. BENSON and B. LUKAJIC gave some details on their proposition; the ITA meetings would occur from september 17-21, 1989, in TORONTO at the occasion of the International Congress on 'PROGRESS AND INNOVATIONS IN TUNNELLING'.

\subsection{Further General Assemblies}

The Executive Council informed the Assembly on the applications received from the People's Republic of China and Netherlands to organize the General Assembly in respectively 1990 and 1991.

The relevant decisions should have to be taken during the 1987 and 1988 General Assemblies.

\section{OTHER BRIEF REPORTS AND DISCUSSION}

\section{a) JAPAN}

Mr. FUKUCHI recalled the International symposium on Undersea Tunnels held last March to commemorate the breakthrough of the Seikan Tunnel. The Symposium was held in close cooperation with the ITA and gathered 259 participants including 34 foreigners; 18 papers were presented followed by fruitful discussions.

The papers will be published in the ITA Journal. 


\section{b) FINLAND}

Mr. LAINE recalled the conference on 'LARGE ROCK CAVERNS' to be held in Helsinki from August 25-29, 1986. 300 to 400 attendants are expected and a ITA Executive Meeting will be held at this occasion.

c) NÖRWAY

Mr. AAS recalled the Symposium on 'STRAIT CROSSINGS'; the definite date has been fixed at October 7-9, 1986, in STAVANGER.

The HYDROPOWER International Conference will be held in June 1987 in OSLO.

\section{c) FRANCE}

Mr. REYNAUD, the AFTES Secretary General, informed the Assembly of the next AFTES International Conference to be held - after Lyon in 1984 from October $21-23,1987$, in BORDEAUX, on the topic 'CITIES AND SUBSURFACE USE'. The first circular was given during the meeting.

\section{e) SWEDEN}

T. FRANZEN 1nformed the Assembly of the next International symposium On 'ROCK STRESS AND ROCK STRESS MEASUREMENT' in STOCKHOLM from September $1-3,1986$.

f) U.S.A.

Mr: LACHEL reported that the r.ext Rapid Excavation Tunneling Conference will be held in NEW ORLEANS from June 12-16, 1987. A special session will be devoted to the new international underground projects.

\section{g) BELGIUM}

W. DE LATHAUWER recalled the next 18 th PIARC World Congress in Brussels from September 13-19, 1987.

\section{h) South Africa}

N. SCHMIDT presented the 1985 report of activity of the South African national committee (SANCOT); it is available at the Secretariat. 
11. PRELIMINARY DISCUSSION ABOUT THE ELECTION OF THE EXECUTIVE MEMBERS

The President recalled that elections are planned for the second part of the General Assembly; he recalled the candidatures :

- for the office of President : E. BROCH (Norway) and HPS VAN LOHUIZEN (Netherlands);

- for the two offices of vice-president : J.F. BOUGARD (France), C. KIRKLAND (United Kingdom), and V. ROISIN (Belgium).

\section{VARIOUS ANNOUNCEMENTS}

a) Working groups

The President informed the General Assembly of the arrangements taken for the meetings of the working groups; he confirmed that the working group 'Seismic Effects' has completed 1ts works, stated that the group 'Standardization' would have no meeting since the animateur and the vice-animateur were absent at the same time, that $\mathrm{Mr}$. LAGRANGE (Belgium) will lead the meeting of the group 'Health and Safety' since the animateur, N. KRIGF (South Africa) was absent, and that he would himself lead the meeting of the group 'Contractual Risk Sharing' as the animateur, J. LEENEY (United Kingdom) resigned.

b) Open Session

HPS VAN LOHUIZEN recalled the programme of the Open Session of Tuesday . June 10 'APPROACHING THE $21 \mathrm{st}$ CENTURY : EXPECTATION AND PERSPECTIVES FOR TUNNELLING AND UNDERGROUND CONSTRUCTION' under the co-chairmanship of J.K. LEMLEY and B. PIGORINI, with P. DUFFAUT (France), H. DUDDECK (Federal Germany), C. GRANDORI (Italy), R. ROBBINS (USA), and Sir Alan MUIR WOOD (United Kingdom) as Reporters.

c) The Swedish delegate called the Executive Council's attention to the propositions that had to be made for the office of secretary General if V. ROISIN was elected as Vice-President.

- 


\section{ELECTION OF THE EXECUTIVE MEMBERS}

- The President reported that France had withdrawn the candidature of $j . F$. BOUGARD to the office of vice-president, in order to follow the propositions of the Nomination Committee. The President pointed out how he esteemed the part of France in the Association, that he respected the French position, and was expecting a French candidature in the future.

The President recalled that the Secretary must not be considered as an Executive Member, and deemed that France could be a member of the ITA Executive Council even if the Secretariat is in France.

- The Member Nations present and represented voted :

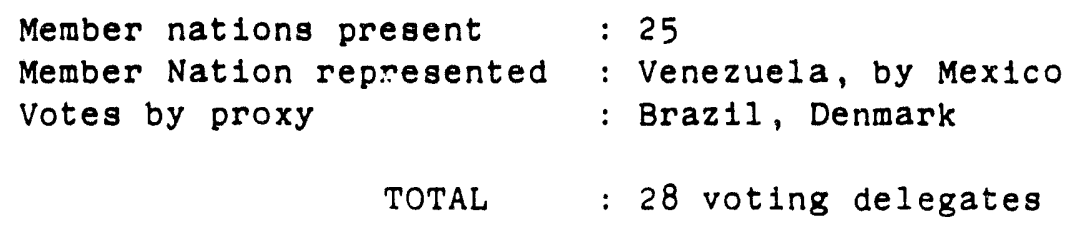

$\begin{array}{lll}\text { President } & \text { E. BROCH } & \text { Norway } \\ \text { 1st Vice-President } & \text { V. ROISIN } & \text { Belgium } \\ \text { 2nd Vice-President } & \text { C. KIRKLAND } & \text { United Kingdom }\end{array}$

14. WORKING GROUPS - REPORTS AND FUTURE ACTIVITIES

\subsection{Cost-Benef1tg of Underground Urban Public Transportation Animateur F. BLENNEMANN (Federal Germany)}

The group has finished a report on 'Examples of Benefits of Underground Urban Püblic Transportation'. Contributions from 11 countries show that a metro system has positive effects regarding travel time, level of service, use of energy, safety, environmental protection, etc... The report will be published at the end of this year. In the fourth lssue of the new ITA Journal.

The main task of the group in the florence meeting was to discuss methods of cost-benefit-analyses for transport facilities.

Written contributions were given up to now from 6 countries. The discusstons and comparison of the ways how this problem is handled showed great 
differences in the various countries. On the one hand cost-benefit-methods are used to a very limited extent in countries where the use of the subsurface is an absolute necessity, for example in Japan. Other countries use quite sophisticated methods to show or even to monetarise the benefits of a metro system.

The reasons are for example that the polftical, soctal and the overall economical situation in a coun.ry can severely influence declisions regarding the use of the subsurface.

The next report will contain descriptions of cost-benefit-methods from several countries. A comparison of the methods and an evaluation of the reports will show the limits of the application of the different methods.

The group has now offictal delegates from 14 countries. The meeting of the group in Florence was attended only by flve delegates from three countries.

We ask the member nations urgently to support the work of the group, because we think that our task can be a valuable contribution to the work of ITA.

The President thanked the antmateur and the General Assembly accepted the presented propositions.

\subsection{Contractual Sharing of Risks - J. VAN DER LINDEN (Belgium) representing $W$. SALTER (USA)}

The working group met twice on Sunday and Monday afternoon. Fourteen members attended the meetings representing 11 countries. The most faithful members were unanimous to regret the absence of the animateur, J. LEENEY, who advised by a letter dated 1st of May that he would not be able to be in Florence and that he wanted to offer his resignation. Unlucky circumstances do not permit him to continue that task of animateur, which he assumed so many years with competence and diplomacy ability.

Hence the group addressed him a letter, undersigned by all, in order to express him gratefulness and great esteem.

A new animateur has been elected, Winfleld SALTER, who already animated the group in the past on certain occasions. For the election of the viceanimateur the very old system of flipping a coin designated J. VAN DER LINDEN. A nomination ex-abrupto brought with it some inconvenients, such as the absence of documents of previous years. In addition postal problems had deprived some members of the reports of the Prague working meetings.

After the first hesitations the group found back its crutse-speed and its enthusiasm, attested by the participation in the discussions of all members without an exception. 
Three subjects Inftlated earlier were reviewed and the amenced texts are proposed to the General Assembly for adoption as ITA Recommendations:

- 'R1ghts of way and permits' (XVII)

- 'Provision of plant, equipment, services and material by the owner' (XVIII)

- 'Alternat1ve tenders' (XIX)

Four other subjects were discussed and amended propositions will be c1rculated to the participants for written comment and decision during the next meeting :

- 'Measurement problems in rock'

- 'Protection of project surrounds'

- 'Measurement problems related to water'

- 'Role of the Engineer'.

On this last item important changes have occured during the last years and the initial proposition of recommendation will be reviewed after additional inquiry amongst member nations.

In the end a questionnalre will also be sent to the member nations in order to make a ITA document inspired by Part IV of FIDIC documents.

The President thanked the animateur and the General Assembly accepted the presented propositions.

14.3. Subgurface Plann1ng - Antmateur M. BARKER (USA)

The working group on Subsurface Planning is dedicated to demonstrating the successful uses of the subsurface and encouraging the proper planning for underground factlities.

Sixteen delegates from nine countries participated in the 1986 meeting Including': Austria, Czechoslovakia, Federal Republic of Germany, Finland, Italy, France, Norway, Sweden, and the Untted States of America.

The objectives of the working group 18 to prepare, discuss, and ultimately publish learned papers that show the effective use of the subsurface and advance th's art and sclence of underground design and construction.

Five formal papers were presented and discussed :

J. GRAN of Czechoslovakia presented a paper on the first underground sewage treatment plant in Czechoslovakia. H1s paper showed that the underground plant had comparative costs to a surface plant. The advantages to going underground were environmental and space considerations. 
P. DUfFAUT of France presented a paper on the legal problems of subsurface use, panticularly the ownership and liability question.

The working group decided to make a speclal effort in this alm to be headed up by the vice-animateur Syver FROISE of Norway.

S. PELIZZA of Italy presented a paper on many significant underground projects in Italy. There were :

a) Gran Sasso laboratory for subnuclear physics

b) Seven underground hydroelectric power plants

c) The Abbadir Lariana underground highway interchange

d) The water collection chamber of the Monteponi Mine.

The working group was most 1mpressed by the survey of Italian projects and proposed that other national representations also $\mathrm{p}$. pare surveys of important underground projects in their countries. Donna AHRENS, the Managing Editor of 'Tunnelling and Underground Space Technology' journal, who attended the meeting, expressed a keen interest in publishing these 'national reports'.

Vice-Animateur Syver ROISE presented a paper on the Norwegtan experience of storing hydrocar'ons in unlined rock cavern. His associate Avild PALMSTROM presented nuw technics for crossing flords in deep tunnels at a $40 \%$ cost saving over surface bridges. He also discusged exploration works on the exploitation of offshore otl flelds by tunneling from land.

The Animateur Emeritur, Birger JANSSON of Sweden, presented a paper on the environmental influence on the demand for legal regulations on the use of subsurface. This paper and its concerns were referred to viceAnimateur FROISE for continuing development.

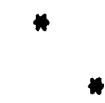

The working group members have published over 30 papers on the effective use of the subsurface.

The Florence meeting will result in additional publishable papers.

The working group expressed its appreciations to the Host Committee for the excellent meeting facilities.

Also, the working group compliments the Executive Council for its increasing support of the working groups, specificaly for encouraging member countries to send active delegations to the working groups and improving the publications of the organisation.

The President thanked the anlmateur and the General Assembly accepted the presented programme. 
14.4. Regearch - Antmateur J.F. BOUGARD (France)

The meeting of the working group, which took place on the 8 th of June 1986, gathered 15 persons representing the eleven following countries : Belglum, Canada, Egypt, France, Germany, Japan, Netherlands, Norway, Soutb Africa, Spain, Sweden.

The representatives of the following five countries wrote not only to be excused but also to make suggestions about this meeting and to send materlals to the works of the working group : Australla, China, Czechoslovakia, Switzerland, United Kingdom.

So similarly to last year, sixteen countries are interested in the activities of the working group. This is encouraging. There are five studies underway and a general survey concerning current and future national research activities is being made.

a) The study related to 'Tunnel boring machines in hard rock' has been started a couple of years ago. As the questionnaires sent to all member nations have not all been answered, new ones w1ll be issued in order to recelve more answers and update the first ones. If answers do not cover all the parts of the world a report will be made about specific continents or areas.

b) A Japanese Reporter General, Mr. Yamamoto, has taken in charge last year a survey on 'shleld methods' and more particularly on slurry shield and earth pressure balance methods. Mr. FUKUCHI has presented the intermediary results of study based on a general inquiry by all concerned nations. Besides, a German Co-Reporter has been appointed. A draft of the final report should be avallable at the next annual meeting. It will take into account the remarks of the working group and the last answer of some nations.

c) Some nations did not yet answer the questions related to the 'water problems during and after the construction of tunnels study'. They will be urged to do 1t. Besides, a coordination will be established with the working group Maintenance and Repair which deals with similar problems in existing underground structures. A preliminary report could be ready next year.

d) A study started last year about 'single shell in situ concrete lining'. As for the previous one, some countrles and particularly Japan which has a good experience in this fleld, will be asked to increase their contributions.

e) Sweden agrees to appoint a General Reporter for a study about 'No1se and Vibration'. Mr. Franzen, representing Sweden, has presented a draft of a questionnalre which will be sent to all member nations. An intermediary report w111 be presented at the next meeting. 
f) During this meeting it has been decided not to undertake any new study this year in order to better concentrate on the current ones. But all member nations have been asked to mention their current and future activities in terms of research, so that the works of the working group will be consigtent with the concerns of a majority of nations. C.E.Tu. of France 18 in charge of this survey and the results of it w11l give a better orientation to these works.

On the while we can say that the activities of the working group have now reached a satisfactory pace.

The President thanked the animateur and the General Assembly approved the presented programme.

14.5. Health and Safety in Workg - M. LAGRANGE (Belgium)

Vice-Animateur, representing the Animateur N. KRIGE (South Africa)

The meeting was attended by representatives from Federal Germany, Japan, South Africa, United Kingdom, and Belgium.

The. agenda proposed by N. KRIGE was accepted.

The definite texts of the Chapters $G$ (Use of Compressed A1r as a Power Source) and $H$ (Work Under Compressed atr) have been approved.

The texts proposed for the chapters :

I - Use of Tunnel Boring Machines and Roadheaders

$J$ - Dealing with water

$K$ - Underground Communtcations

have been discussed for a long time and amended.

Without going into deta1ls, the purposes of the modification motions are :

- to olmplify and generalize the 1ssued ideas

- to adopt these texts in the best way to the next of the previous chapters.

The comments w1ll be transmitted to $N$. KRIGE who will certainly be pleased to the definite texts which could be submitted for agreement next year.

The group has this way finished the elaboration of 11 complementary chapters concerning Safety and Health in the underground works.

It is an excellent synthesis work which should be used all over the world. 
The working group suggests that the definite texts could be transmitted by ITA to every member nation who would do the necessary to transmit them to all their national members.

For the future, in spite of the fears arisen this year, some excellent proposals have been made. We suggest in this spirit to go on fixing the safety rules for :

- safety as it would have to be taken into consideration from the moment of the project study (safety in planning of turinels);

- safety during maintenance, repair or survey of tunnels;

- safety during execution of pipe jacking;

- explosion risks;

- the necessary safety for small diameter works;

- the general health problems during the underground works (dust chemical agents, gas, incidental deficiencies, etc.).

These rules could be established either as new Chapters or as addendum to the existing Chapters.

The group wishes to express his gratefulness to N. KRIGE for all the work he performed and hopes to find him again as a present president next year.

The President thanked the animateur and the General Assembly accepted the presented programme.

14.6. Maintenance and Repair of Underground_Structures Animateur A.J. HOWARD (United Kingdom)

This year fourteen persons, representing ten nations, attended the Group meeting. This is an encouraging increase in response to the work of the Group, which we hope will continue. Other nations have contributed to the work of the Group during the year, but were not able to be represented in Florence.

On last year's report it was mentioned a paper entitled 'Civil Engineering Records of Underground Structures' which the Group had been preparing. Th1s paper has now been submitted for publication by the Association. The paper stresses the importance of comprehensive records, which will commence during project investigation and will continue during construction and the service life of the faclitty. Guidance is given concerning the content of record sets. Although only a brief outline document, the 
group belleves that this paper will be a strong encouragement to Promotors and Englneers to plan for the future when constructing in the present.

During the year the Group's task, as approved by last year's Assembly, has been to study the long-term adverse effects of infiltration of water and other liquids into tunnels from the surrounding ground and methods of counteracting these effects. A number of case histories had been sent to the Animateur and these were discussed at the meeting together with other case histories in the knowledge of those present. As usual, the discussion was lively and informative, and lliustrated the many ways in which the tunneller's old enemy, water can continue to cause trouble long after the battles during construction have been won.

During the coming year the Group will have the support of STUVA, as decided by the Executive Committee. It was decided that further case histories relating to water problems will be sought from as many nations as possible to be sent to STUVA by the end of October 1986 at latest. STUVA will study these on behalf of the Group and will prepare a report identifying the problems encountered and their causes, the solutions to the problems which have been adopted, and their effectiveness.

The report will be avallable for discussion by Group members at their next meeting in March. In a cense this report will never be complete : but if there is a wide response to the call for case histories, the result will be of great assistance to all engineers involved in this important aspect of tunnel work.

The Animateur emphasized that the present topic is but one of a number of important matters which the Group has identified as appropriate for study.

The Group is encouraged by other working groups to consider matters such as the ageing of shotcrete - and the effects of additives on this - and the much wider field of the influence of maintenance requirements on design.

The Group seems assured of valuable work for a long time to come.

The President thanked the animateur and the General Assembly accepted the presented programme. 
14.7. Genera1 Approaches to the Design of Tunnels

-Animateur H. DUDDECK (Federal Germany)

Seventeen engineers from twelve member nations attended the two meetings in Florence.

The Anlmateur had prepared a first draft of a paper on 'Guidelines for the Design of Tunnels' ( 39 pages) which was sent to most of the official members of the working group ahead of the Florence Conference.

At the sessions this first draft had been discussed page by page. Some chapters have been amended and decisions have been taken on alternative proposals.

The guidelines cover the general approach to the structure design of underground openings. The paper has the following chapters :

1. Scope of the guidelines

2. Outline of the general approaches

3. Site investigations and ground probing

4. On structural design models for tunneling

5. In-situ monitoring and its interpretation

6. Recommendations for the structural detailing of the lining

7. Appendix : References on international and national recommendations.

The guidelines are emphasizing the necessity to view all the aspects of the structural designing before and during the excavation as integral parts of an interactive procedure combining ground behaviour : comprisational modelling and in-situ monitoring as a unity.

The chapters try to gather the experiences made so far by the member nations of the ITA and are intended to be written so that the guidelines will be open for future developments.

Some members of the working group were kind enough to prepare some sections of the amended paper. The animateur has in mind to write a second draft of the guidelines before the end of 1986. This draft will then be sent to all members of the working group asking for written comments.

Since the guldelines are touching also objectlve of other ITA working groups, the second draft will also be sent to the corresponding animateur.

It is hoped that the final version of the guidelines may be submitted to the next meeting in Melbourne or closely after the Australian Conference. 
The publication may be posstble in 1987 or 1988. The Executive Council is asked. to decide whether the working group - after publication of the guidelines - may be dissolved, providing chances for other objectives of the ITA.

The President thanked the Antmateur and the General Assembly accepted the presented programme.

14.8. Catalogoue of Tunnels - Animateur S. KUWAHARA (Japan)

The peeting of the working group was held on June 8 in Florence with elght participants from seven countries (Belgium, Czechoslovakia, Italy, Japan, South Africa, United States of America, West Germany).

The members of two countries (Cuba and Egypt) were not able to attend the meeting but to exchange the information after the meeting.

All the participants admitted the necessity to record the tunnel projects being under construction and completed in the member nations. In spite of 10 years activity of ITA working group to collect the numerous information on construction record, this information was utilized effectively for future reference and study. Taking this situation in consideration the animateur proposed to the attendance the systematic filing method by applying computer data processing. This idea enables to summarize, classify and analyze all data according to the request of members.

Based upon the original data reported by seven countries (Egypt, Iceland, Austria, Italy, Japan, USA and West Germany), in 1905, several kinds of computer output data with tables and figures' were presented, explained and discussed.

In order to grasp the trend of the worldwide activities of tunnel construction, being given the code number, the individual original data have been stored in disks and classified by the computer, by the country, by the status of tunnel, by the kind of tunnel, by the construction method, by the cost of construction, by the length of tunnel, oy the excavated volume, etc.

Combining these major factors as the sorting keys of the individual data, we could develop the different kinds of analysis and evaluation of worldwide tunnel projects.

The participants realized that the working group should aim two subjects. One is to obtain statistic features, and the other is to evaluate the technical and economic figures. However, the aspect of the latter seems a little diricult to collect the specific data (le accurate geological features, construction period, working shift, highest productivity, speccifled equipment and termed construction cost).

So, the working group should be concentrated in carrying out the former subject properly. 
At this moment the technical and commercial matter should be referred by the direct contact with reporter or client in correspondence with existing forms.

So as to make the output data accusato and more useful, al1 the member nations are requested to submit the annual report of tunnel. In 1985 we have received only seven countries reports out of 33 member nations.

We would like to request that ITA Executive Committee should stress this fact to member nations and force them to assign the reliable person to response the proper report meanwhile the working group will take action to send to the registered person in charge the output data to encourage them to report their records in return.

In case that our coming one year effort of collecting data from the member nations does not improve this situation, we should dissolve the catalogue working group to avoid waste of time and money in both manpower and computer.

The first trial of data processing was volunteered by the staff of the animateur's organisation. Since the second step is requested to modify the programme, they might be involved in 1t. But no actual data processing would be carried out, unless any kind of financial support is provided by the ITA Executives and sufficient original data are submitted from the member nations.

However, every participant emphasized the necessity to continue the activities of the working group, because they know there is no organization to grasp the statistic aspect of tunnelling works over the world except the ITA working group.

The President thanked the Animateur and the General Assembly accepted the presented programme.

14.9. The President thanked all Animateurs and participants in working groups activities. Concerning the Group Standardization, the President stated that the Executive Counc1l would make propositions on its operation in a next future.

\section{REPORT ON THE OPEN SESSION}

HPS VAN LOHUIZEN recalled the topic of the Open Session held on Tuesday 10 gathering about 500 participants - 'Approaching the 21 st Century : Expectation and Perspectives for Tunnelling and Underground Construction'. He gave a brief summary of contributions presented by Mssrs. DUFFAUT, DUDDECK, GRANDORI, MUIR WOOD and ROBBINS, and of following discussions under the Presidency of $B$. PIGORINI and J.K. LEMLEY; lastly he reported that all contributions will be published in the new ITA Journal. 


\section{H.C. FISCHER' 8 INTERVENTION}

The Past President of the ITA, H.C. FISCHER of Sweden, presented a remarkable intervention on his thoughts about the Association, its purposes, its future connected to four concerns :

- The technical reflection: what - why - where - how

- The communication : Influence - recommendation

- The training : students - teachers - documentation

- The recognition of international organisations : as non zovernmental organisation

\section{APPOINTMENT OF THE SECRETARY GENERAL}

It is planned in the Statutes that the office of Secretary General will complete on December 31 of this year; considering that the next General Assembly will occur in March 87 , the President, on behalf of the Executive Council, proposed to have the present Secretary acting as Secretary General up to the next Assembly, during which the Secretary General will be regularly appointed.

The General Assembly accepted these propositions.

\section{NOMINATION COMMITTEE}

Following a proposition made by the President the General Assembly confirmed the appointment of the following Nomination Committee :

- Honorary President

- Past President

- Retiring President

- President
A M MUIR WOOD
$G$ GIRNAU
$J$ K LEMLEY
E BROCH

\section{OTHER BUSINESS}

The President deemed it necessary to take the occasion of a transition time for. the General Secretariat to think over the evolution of the respective tasks of the Secretary General and Secretary, also taking account of the new arrangements made this year for the Journal and working groups. He requested the member nations to transmit their suggestions. 
20. CLOSING ADDRESS

20.1. President LEMLEY thanked the Italian organizers, gave a brief recall of the major events of his 3-year presidency, and thanked all those who assisted him during this period.

20.2. The new elected President E. BROCH thanked President LEMLEY for his sustained action for the ITA as an Executive Member during 7 years; he emphasized his role in the creation and development of Affiliate Members, and hoped he will pursue his efficient action as Retiring President.

20.3. President BROCH closed the session, thanking the Assembly for his election; he hoped he will be able to go on promoting the Association according to the trend given by the first President AM MUIR. WOOD, and in the spirit of good friendship which is maintained within the Executive Counc1l and betwean the delegates of the represented nations.

The Secretary General

V. ROISIN

The Retiring President
The Secretary

C. BERENGUIER

The President
J.K. LEMLEY
E. BROCH 
Quarterly Activities Report

June 15--September 15, 1986

This report covers continuing activities of the U.S. National Committee on Tunneling Technology from June 15 through September 15, under U.S. Bureau of Mines Grant Agreement No. G0167021. It is submitted in accordance with provisions of the grant.

\section{FINANCIAL STATOS}

In response to the committee's proposal dated January 1986 , a total of $\$ 184,000$ has been obligated and received. Of this amount, $\$ 169,000$ was transferred via the referenced grant agreement and $\$ 15,000$ was provided directly by a separate contracting mechanism. Receipt of support from two sponsors is pending.

\section{MEETINGS}

\section{Annual Meeting}

The annual meeting of the committee was held in Washington, D.C., on June 27-28, followed by a field trip on June 29 to several WMATA construction sites. The executive committee convened the afternoon of June 27 and the parent committee convened for a full-day session on June 28. The primary focus of the annual meeting was consideration of program initiatives addressing current and developing challenges to the constmuction and performance of underground structures. Among the subjects discussed by the committee were the following:

- adaptability, performance, and rehabilitation of infrastructure systems (urban and ex-urban): methodologies for evaluation, techniques for determining existing conditions, procedures for improving or expanding functions and capabilities, and criteria for planning, scheduling, and managing the process.

- quality assurance: standards of practice and development and implementation of programs consistent with criteria and constraints established for site characterization, design, construction, operation, and performance of underground structures, and particularly when conformance must be validated and demonstrated.

- competition between forelgn and domestic firms: what are the factors underlying the apparently decreasing ability of domestic firms to compete with forelgn firms, what is the basis for increasing forelgn participation in domestic firms, what are the foreign strategies that suggest modifications in common industry practice and/or traditional roles of the public and private sectors, what are the effects of competitive imbalance on the economic vitality and technical capabilities of domestic firms, and what are the risks that continuing impalred competitive ability poses for advances in technology and practice required to meet domestic demands for improved and increasingly sophisticated underground construction projects for a variety of purposes. 
- liability and risk sharing: the contributors to unreasonable liability requirements and Inadequate sharing of risk, the manner in which they singly and together foster overconservatism and excessive costs, stifle innovative design, discourage the development and application of new technology, reduce the ability to meet requirements for expansion and renovation of the infrastructure, and hinder construction of large, complex projects serving critical purposes.

- geotechnical site characterization: needs, strategies, and technologies for determining and evaluating conditions over large extents and at great depths, especially when extraordinary detail and substantiation are required for project performance or when characterization is constrained and potentially significant unknowns must be accommodated by flexible design provisions and construction procedures.

- groundwater inflow: methods for more precise prediction and evaluation during exploration and design as pertains to construction procedures, post-construction operation, and performance to design, particularly when the ability to control inflow or maintain continuous removal within strict limits is critical to project feasibility.

A highlight of the annual meeting was a comprehensive review of plans for the Superconducting Super Collider (SSC), which is intended to extend the boundaries of knowledge in particle physics. Dr. L. Edward Temple, Jr., Director of the Construction, Environment, and Safety Division within DOE's Offlce of Energy Research, presented an overview of the concept, characteristics, cost, and proposed schedule for the SSC. Dr. Timothy E. Toohig, of the Conventional Facilities Division, Central Design Group, outlined the technical requirements for the underground facilities, siting considerations, development of generic site models and tunneling and cost models, and the strategy for project development.

\section{Agenoy Roundtable}

A half-day roundtable meeting of representatives of sponsoring agencies and committee officers was conducted the morning of September 15 at the Joseph Henry Bullding, Washington, D.C. The meeting opened with an address by the Executive Director of the Comilission on Engineering and Technical Sytstems. The agenda was planned to include three items: briefing on the status of current committee activities, review of plans for potential efforts to ensure a technical scope incorporating agency interests in a manner responsive to program needs and objectives, and interagency discussion of the focus and requirements of cur rent technical programs. Following adjournment, participants were afforded an opportunity to continue discussions during an informal luncheon gathering.

\section{NEN MEMBERS OF THE COMMITTEE}

The nominee for the office of vice chairman and the slate of seven nominees proposed for appointment for three-year terms ending June 30, 1989, were approved by the Chairman of the National Research Counc1l. The new vice cha1rman of the committee is Thomas D. O'Rourke, Department of Civil and Environmental Engineering, Cornell University. Professor O'Rourke will serve as vice chairman unt1l June 30, 1987, when he will succeed as chalrman for the perlod July 1, 1987 to June 30, 1988. 
The Individuals appointed as members of the committee are:

From Academia/Research

Jaak J.K. Daemen, Department of Mining and Geological Engineering, University of Arizona

Boyd C. Paulson, Jr., Department of C1vil Engineering, Stanford University

From Government

Joseph W. LaComb, Test Construction Division, Defense Nuclear Agency

James D. Washington, Office of Engineering, Federal Highway Administration

Designated Representatives

Richard E. Gray, GAI Consultants (Geological Society of America)

Susan Nelson, Execut1ve Director, AUA (American Underground-Space Assn.)

Joseph W. Neudecker, Los Alamos National Laboratory (Institute of Shaft Drilling Teohnology)

A roster of the current committee membership is provided as Attachment 1.

\section{INTERNATIONAL TUNNELLING ASSOCIATION}

The 12th General Assembly of the ITA was conducted during the previous quarter and described in the report for March 15 to June 15, 1986. The formal minutes of the General Assembly, distributed by the ITA Secretariat during the current quarter, are provided as Attachment 2.

\section{SPECIAL PROJECT}

The report review process, which provides for independent peer evaluation of findings of studies conducted by units within the National Research Council, has been completed for "Advances in Technology for the Construction of DeepUnderground Facilities." The report, a joint undertaking with the USNC/Rock Mechanics, will be distributed during the next quarter. 


\section{U.S. NATIONAL COMMITTEE ON TUNNELING TECHNOLOGY}

Activities Report

September 15, 1986--March 15, 1987

This report covers continuing activities of the U.S. National Committee on Tunneling Technology from September 15 through March 15 under U.S. Bureau of Mines Grant Agreement No. G0167021.

\section{FINANCIAL STATUS}

The total funds recelved in support of the committee's activities for the program year is $\$ 184,000$. Agencles contributing through the referenced grant agreement are the Air Force office of Sclentific Research, Belvoir R\&D Center, Bureau of Mines, Bureau of Reclamation, Defense Nuclear Agericy, Department of Energy (Office of Geologic Repositories and Office of High Finergy and Nuclear Physics), and Nuclear Regulatory Commission. The contribution from the Corps of Englneers was provlded by a separate contracting mechanism.

\section{SLIDE SETS ILLUSTRATING TUNNELING PRACTICE}

The Subcommittee on Education and Training completed two sets of sildes with descriptive commentary. The set titled "Geologic Mapping and Exploration" includes 57 slides and covers preparation for subsurface geological investigations, special maps, subsurface investigations, geophysical investigations, and geological mappling and measuring of underground openings. The se' "IInIng Large-Dlameter Rock Tunnels: Case History of Water Tunnel No. 3 (New York City)" Includes 53 slides covering operations prior to concrete placement, delivery and placement of concrete, and supplementary operations. The slide sets will be reproduced and are expected to be avallable for distribution in July 1987.

\section{INTERNATIONAL TUNNELLING ASSOCIATION}

A three-member delegation was approved to provide formal representation for the United States at the 13th General Assembly of the ITA. The voting delegate will be Mr. Dennis J. Lachel, a past chalrman of the committee and member of several previous delegations. The two other members of the delegation will be Mr. Michael B. Barker, Anjmateur (chalrman) of the Working Group on Planning Subsurface Use, and Mr. Winfleld 0 . Salter, Anlmateur (chalrman) of the Working Group on Contractual Sharing of Risks. The General Assembly is to be held March 23-27 in Melbourne, in conjunction with the conference "Tunnel Australla 1987: Bore or Blast." 
A new Journal for the ITA, Tunnelling and Underground Space Technology, has bren inaugurated to combine the editorlal and publishing resources of two f vlously separate journals--Underground Space and Advances in Tunnelling Te. Inology and Subsurface Use. Unt1l the merger, the latter fournal was the off.clal publication of the ITA. The new Journal is published by Pergamon press and the editorlal offices are housed at the University of Minnesota. The 17-member editorial board includes 8 individuals from the united States, many of whom are current or former members of the U.S. National Committee and its special project subcommittees. The cover page and contents for the volumes recelved during the reporting perfod are included as Attachment 1.

\section{SEPARATE PROJECTS}

The committee is developing the scope of a study to consider contractual issues for construction of the underground conventional facilities of the superconducting Super Collider. The study, as envisloned, would be undertaken by a specially appointed subcommittee and conducted as a separately funded project.

The committee's views and assistance have been solicited for two activities that fall within the purview of the Commission on Engineering and Technical Systems. One is a cross-commission effort to evaluate 1ssues for infrastructure innovation and the other relates to a long-term, international scientific and engineering program to mitigate the incidence and effects of natural hazards.

\section{PUBLICATIONS}

In Print

Tunneling Technology Newsletter No. 55 (Attachment 2)

Tunneling Technology Newsletter No. 56 (Attachment 3)

\section{In Press}

Advances in Technology for the Construction of Deep-Underground Fac1lities

In Progress

Tunneling Technology Newsletter No. 57 


\section{TUNNELLING AND UNDERGROUND SPACE TECHNOLOGY}
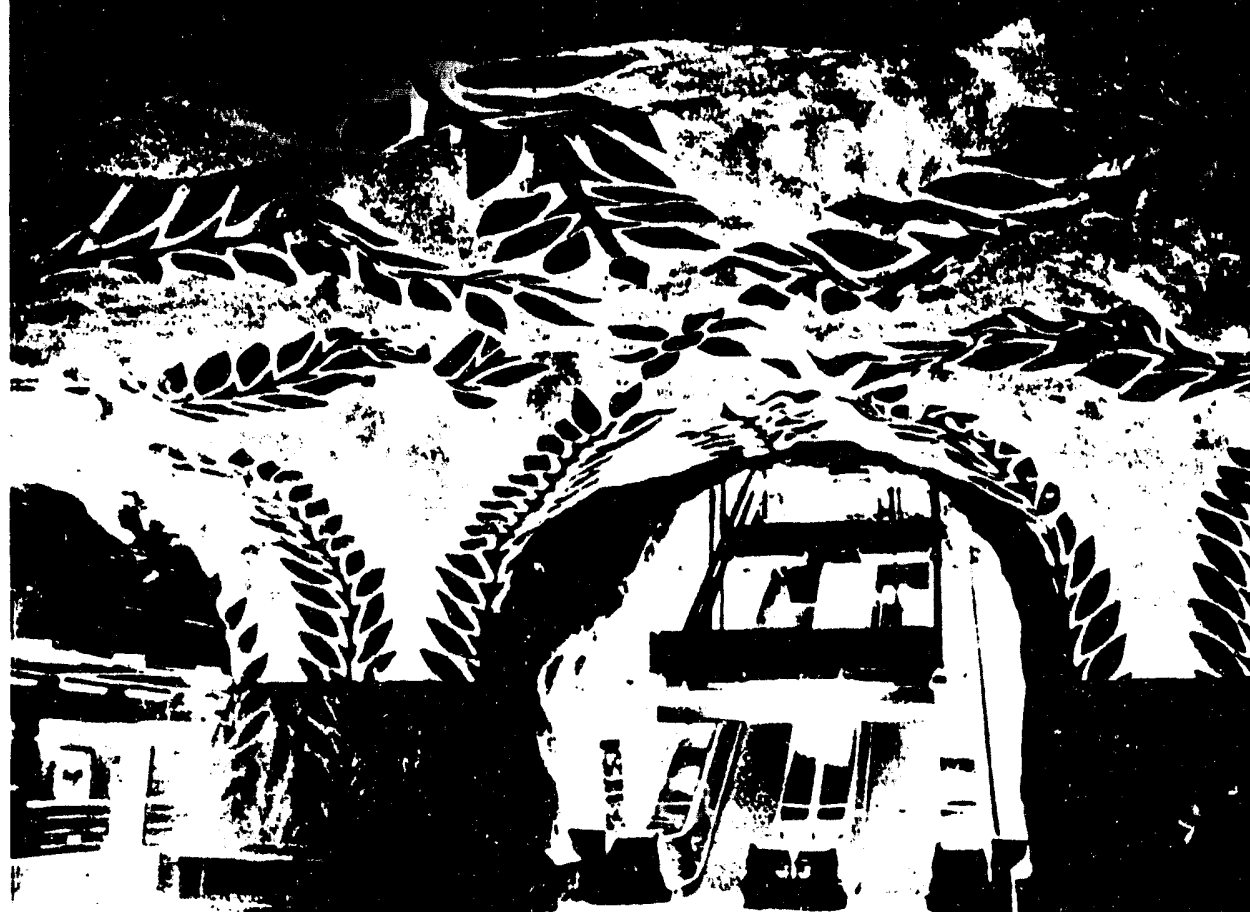

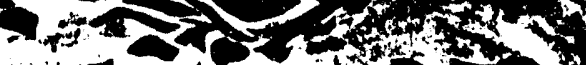
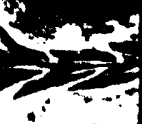
ing
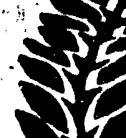

Inside

- Warsaw's first subway line

- Four energy-saving underground buildings

- Subsurface space use in Iceland

- Tunnel research studies from India and China

- An underground shopping mall for Japan's Yukohama station

\section{and more}

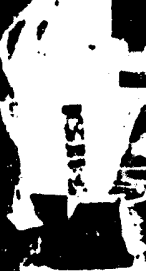

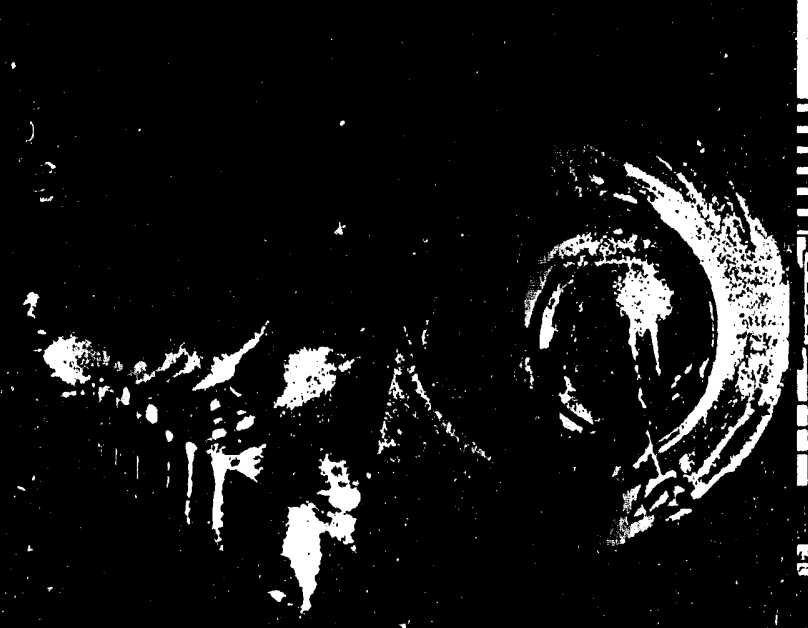
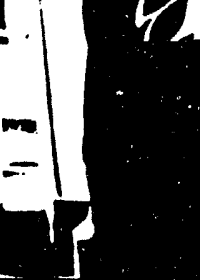

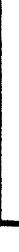
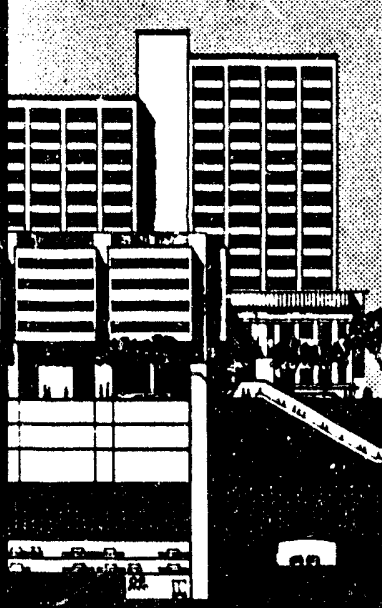

PERGAMON PRESS

OXFORD • NEW YORK BEIJING • FRANKFURT SÄO PAULO - SYDNEY TOKYO • TORONTO

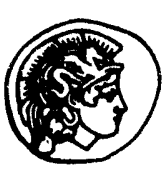




\section{TUNNELLING AND UNDERGROUND SPACE TECHNOLOGY}

Volume 1, Number 1

PLANNING \& DEVELOPMENT

TUNNELS \& DEEP SPACE

Over the past 25 years, Warsaw's district heating system has nearly tripled in length - and it is still expanding. The author traces the history of the system's development.

Maîtrise de l'énergie et aménagement du sous-sol: l'exemple français Jacques Bregeon et al. This paper discusses three areas related to the use of the subsurface and energy policy in France: (1) the underground storage of hydrocarbons; (2) low-energy geothermy; and (3) subways.

\section{The Use of the Subsurface in Reykjavik, Iceland}

Haukur Tómasson Iceland's capital has abundant riches in the form of existing hollows in rock, formed through geological forces. But the city has yet to take full advantage of its subsurface resources.

Case Study of an Underground Shopping Mall in Japan:

T. Tatsukami

Underground shopping malls are a logical solution to problems associated with Japan's densely populated cities. This article traces the development and construction of one such mall, constructed around the Yokohama subway/railway station.

After eight years of planning and construction, Czechoslovakia's Čierny Váh pumped storage power plant was put into operation in $1982 . \% 2$ author discusses its construction, capacity and operation. The authors provide a review of the literature concerning the squeezing pressure phenomenon, and discuss the development of a criterion for predicting rock pressures under squeezing ground conditions. In this second part of the paper, the researchers analyse the results of their field data.

49

\section{Design and Performance of Shotcrete-Bolting Support for a Tunnel in a Special Weak Rock}

Tao Zhen-yu

In China, a hard rock characterized by concealed, highly developed microcracks presents problems for tunnelling projects. The author discusses a new approach to providing support for this type of weak rock.

\section{Model Test Study on Double Lining of Tunnels}

Liu Piede A research study finds that the use of double lining for tunnelling projects in soft rock masses helps maintain the stability of the surrounding rock, decreases stress on the lining, and provides a higher bearing capacity than does a single lining.

\section{EARTH SHELTER \& ARCHITECTURE}



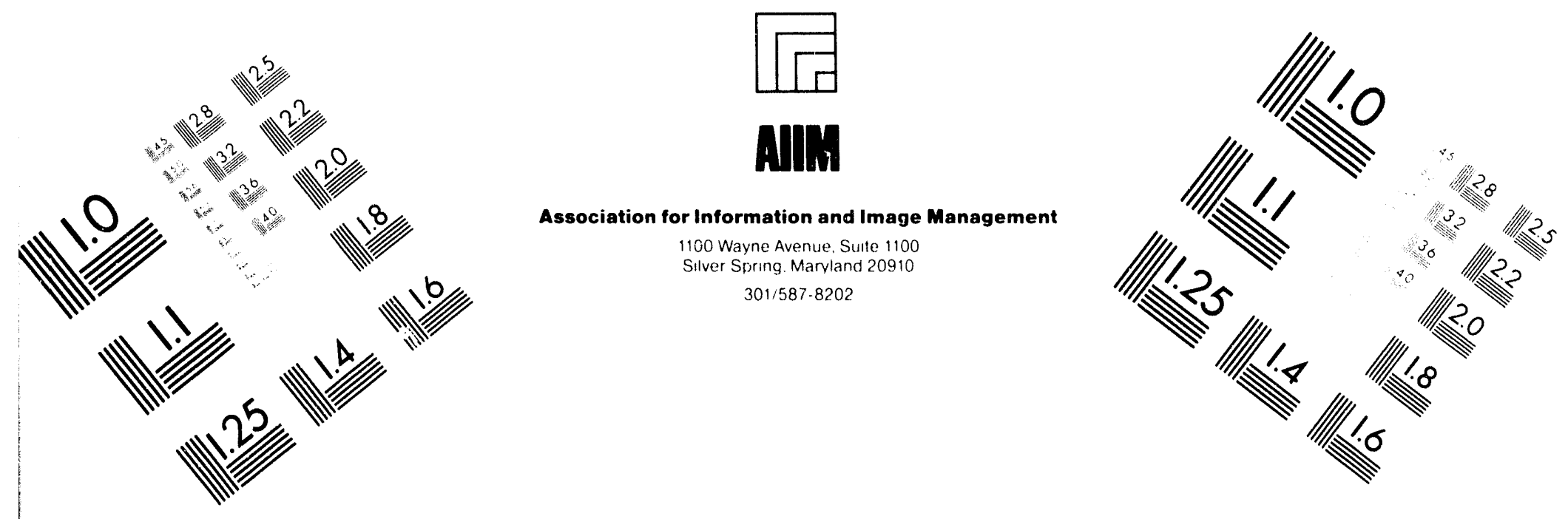

\section{Centimeter}

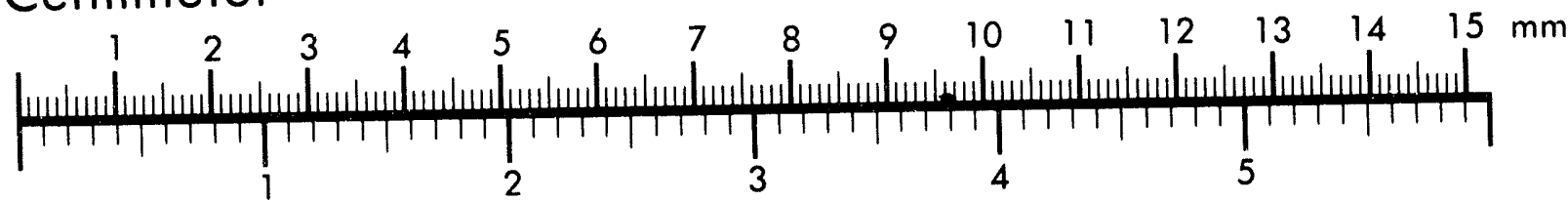

Inches
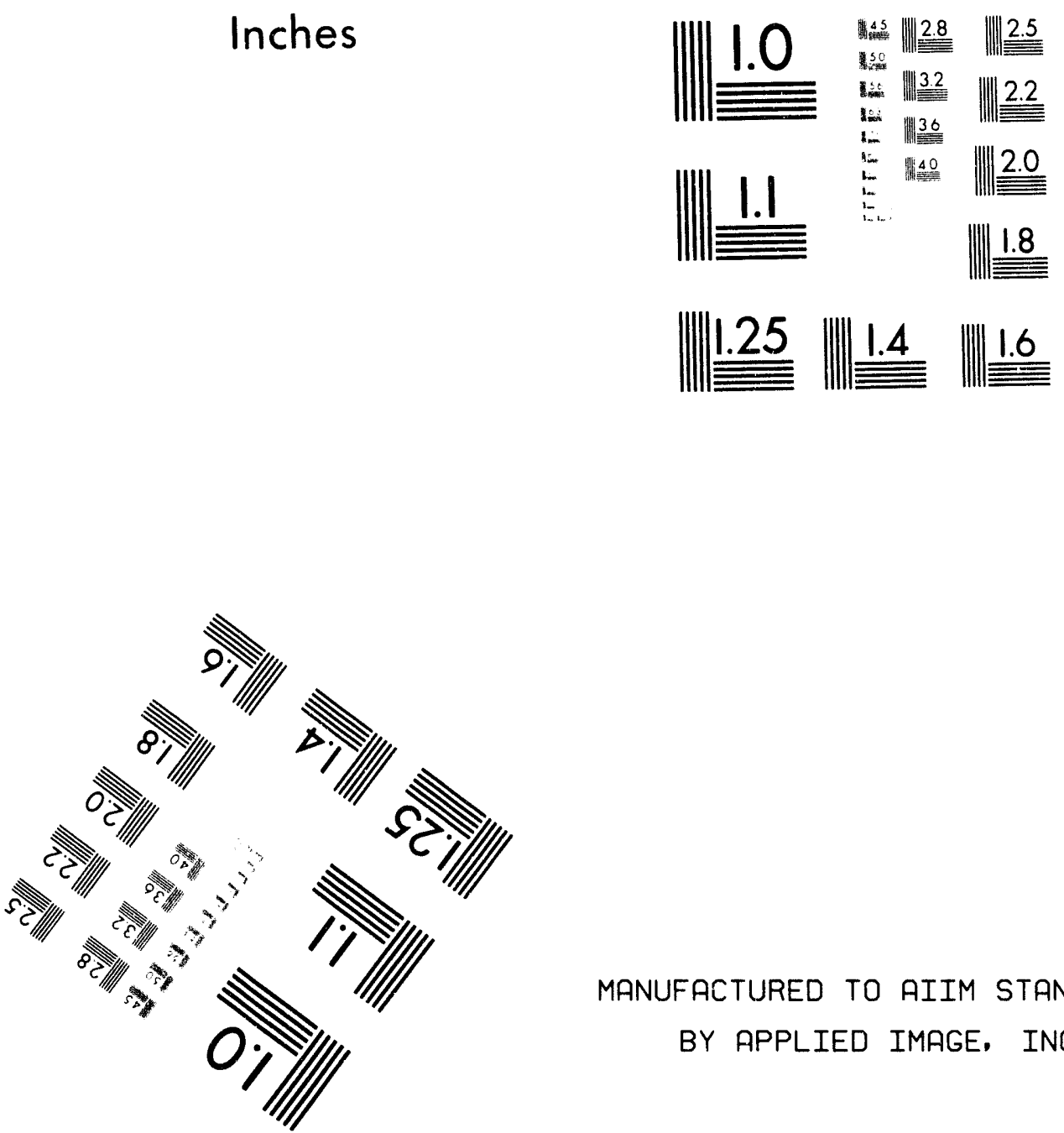

MANUFACTURED TO AIIM STANDARDS

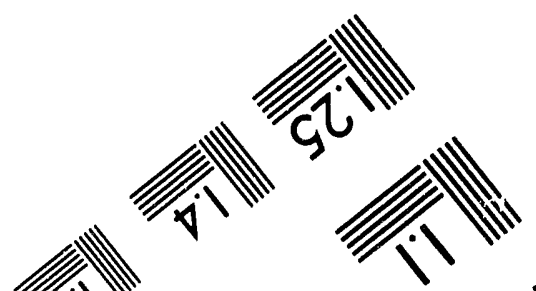

BY APPLIED IMAGE, INC. 

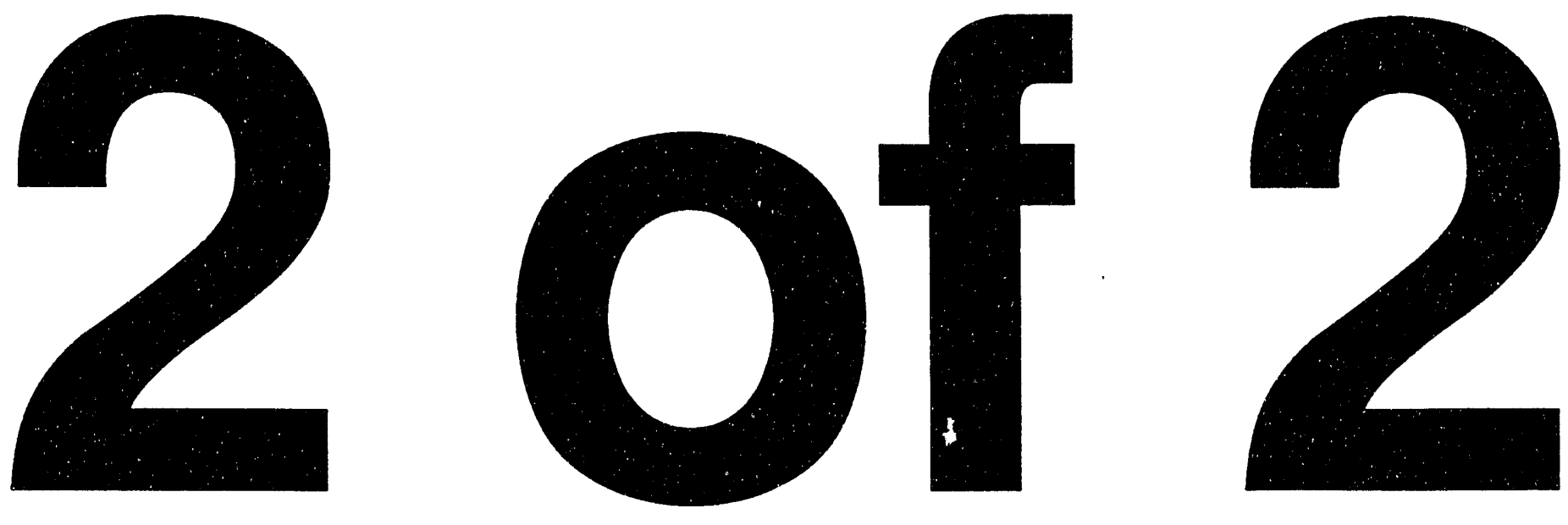
Underground space use is an important component in Yugoslavia's civil defence planning. Many dual-purpose civil defence facilities are being built below the surface.

$71^{\circ}$

\section{Post-Occupancy Evaluation of Residents of Single- and Multi-Family}

\section{Earth-Sheltered Housing}

Janet Bartz

A study finds current residents of earth-sheltered homes to be very satisfied with their residential environment. This article discusses the socio-economic characteristics of the respondents and the characteristics of the earth-sheltered homes studied.

On the cover: (Top) the Stockholm subway; (bottom left) bifurcated tunnel in Chicago's Tunnel and Reservoir Plan; and (bottom right) a section drawing showing both cut-and-cover and deep mined space uses.

Reproduced with the kind permission of Harza Engineering Company and John Carmody.
89 News and Comment

95 Publications

98 Meetings

101 ITA Pages

ISSN 0886-7798 (799) 


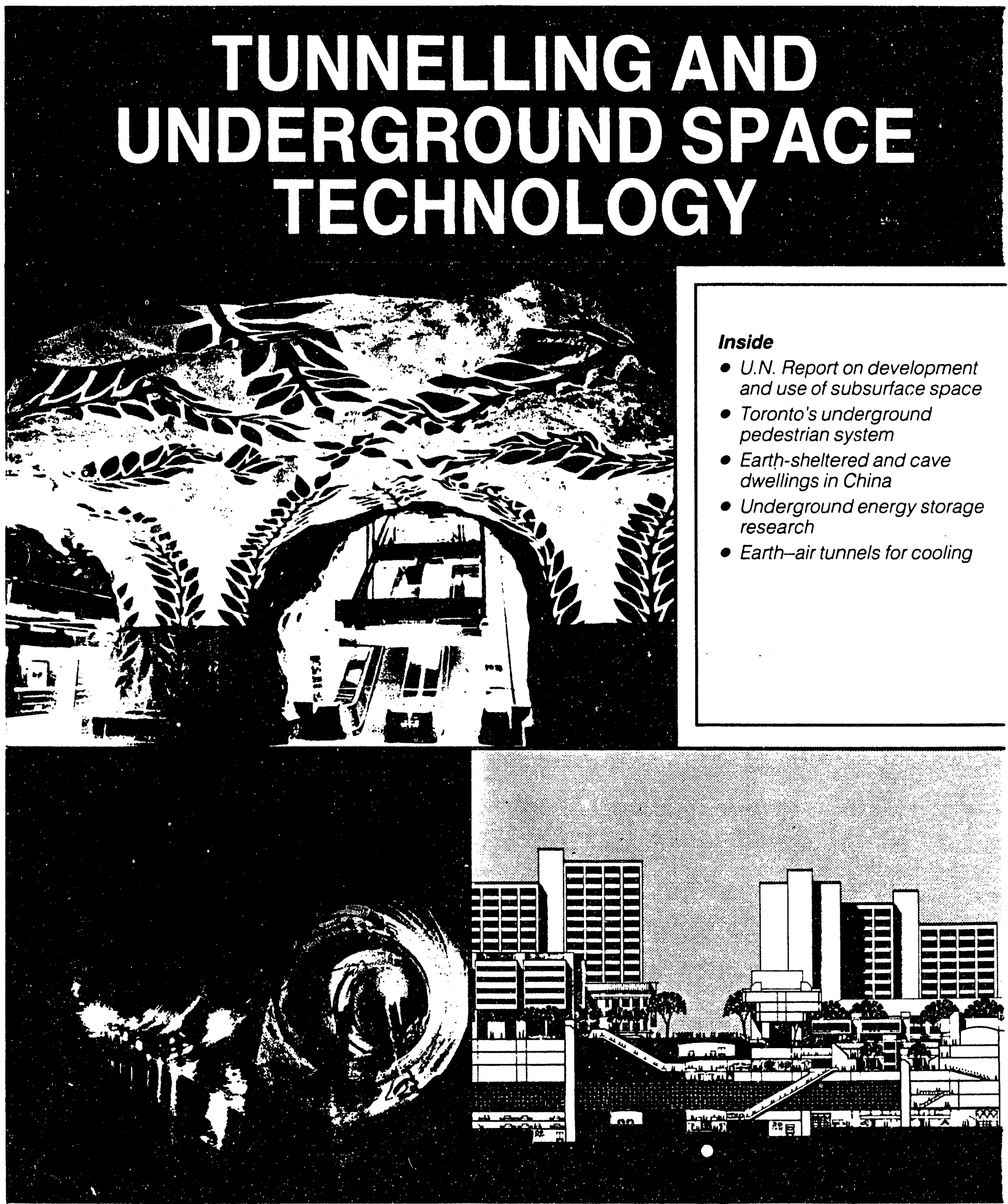

Published and distributed on behalf of the

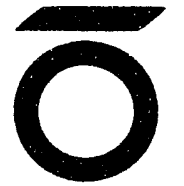

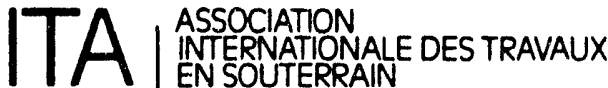

PERGAMON PRESS

OXFORD - NEW YORK BEIJING $~ F R A N K F U R T$ SAO PAULO - SYDNEY NTERNATIONAL
TUNNELINE
ASSOCIATION

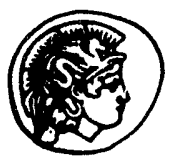


Volume 1, Number 2

$113 \quad$ Editorial

Jack $K$. Lemley

FEATURE REPORT

115 The Development and Utilization of Subsurface Space

S. Magnus Bergman A progress report to the United Nations examines subsurface space throughout the world in terms of both its current usage and its potential for ameliorating surface crowding and providing basic services.

PLANNING \& DEVELOPMENT

145 Toronto's Underground Pedestrian System

Michael B. Barker

A case study summary shows why this Canadian city's subsurface pedestrian network is one of the world's best examples of comprehensive, well-planned subsurface systems.

An Evaluation of à Sanitary Sewer System Using a Computer Model

Christopher B. Burke et al. An engineering team uses a computer model to analyse and recommend improvements for a sewer system in Indiana.

\section{EARTH SHELTER \& ARCHITECTURE} While China's cave dwellings represent substantial land, energy, and construction cost savings, their interior environment must be improved if their use is to continue. The authors explore suitable ways to improve waterproofing and dampproofing techniques for cave dwellings.

The Future of Earth-Sheltered Architecture in China's Farming Villages

Yasuyoshi Hayashi Although increased income of farmers has led to a demand for more modern construction techniques and architectural designs, earth-sheltered architecture may still play an important role in China's farming villages.

Contrary to popular belief, the environment in earth-cave dwellings - such as those typically found in northwest China - may be beneficial to human health. The author examines the interaction between health and environmental factors as they relate to cave life. In experiments with an earth-air tunnel system, researchers in India have found that such a system has considerable potential for conditioning outside air, particularly in summer.

\section{ENERGY STORAGE}

Cost comparisons show that many types of underground heat sources are well-suited for seasonal heat storage, and that a number of types of heat stores can be built cheaply enough to produce low-cost heat. in rock. 


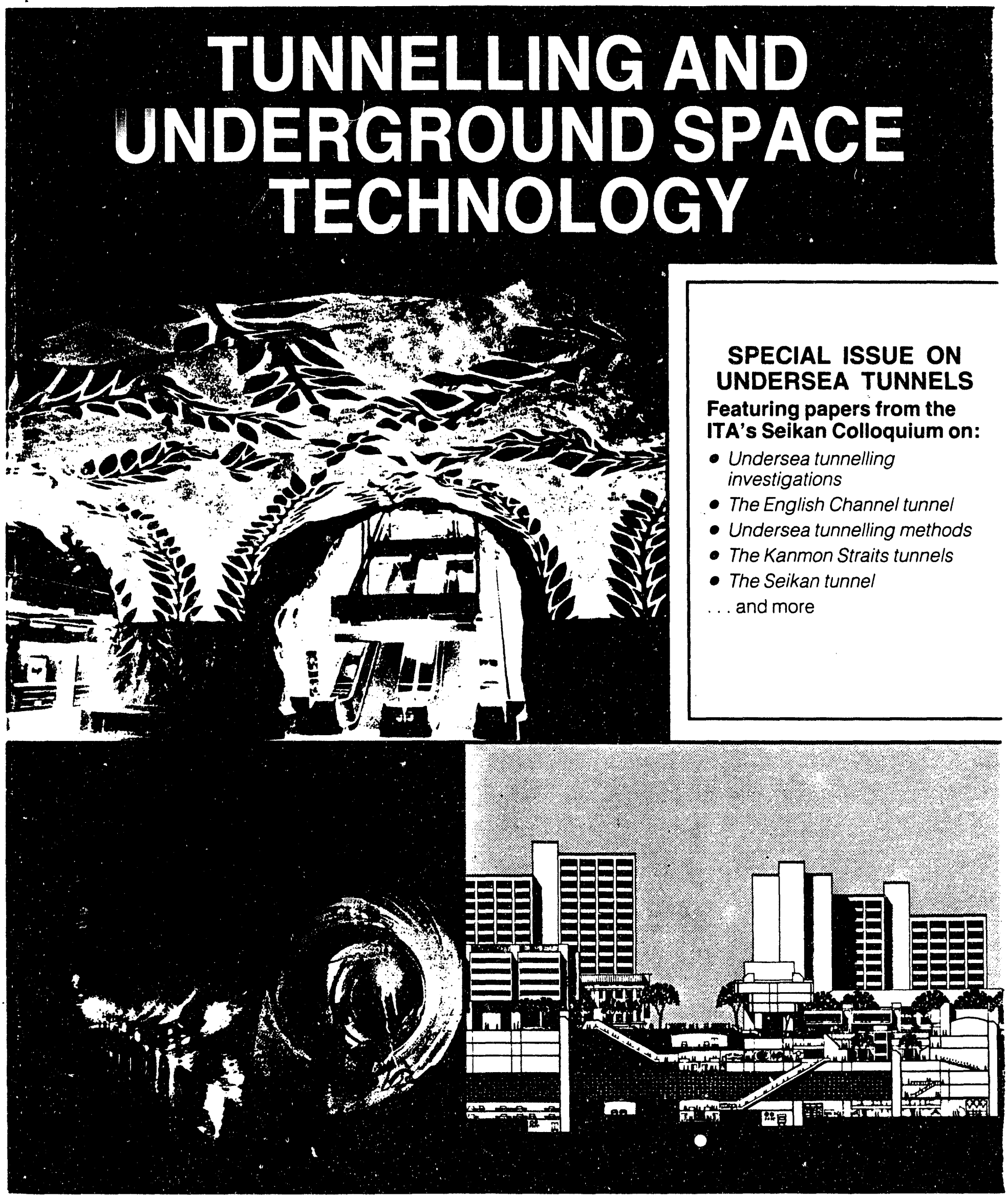

Published and distributed on behalf of the
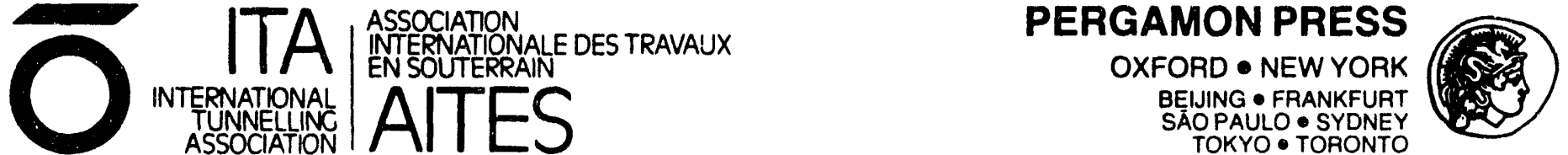


\section{TUNNELLING AND UNDERGROUND SPACE TECHNOLOGY}

Volume 1, Numbers $3 / 4$

$223 \quad$ Guest Editorial

225 Keynote Address to the Seikan Colloquium

G. Fukuchi

UNDERSEA TUNNELLING INVESTIGATIONS

$229 \quad$ Engineering Geological Investigations for a

Subsea Tunnel for an Oil Pipeline across the Hjeltefjorden Strait

E. Broch and

The authors discuss planning and engineering geological investigations for a subsea tunnel to transport crude oil across Norway's Hjeltefjorden Strait.

Geological and Geotechnical Studies for the Gibraltar Tunnel

A. Villanueva and J. M. Serrano Research currently underway is studying the feasibility of alternatives for a link between Spain and Morocco via the Straits of Gibraltar. The authors describe the planning and results of the studies to date.

A repository for waste from the operation of Swedish nuclear power plants is being built beneath the sea on the east coast of Sweden. The authors focus on the construction of the access tunnels, which pass through a regional fault.

THE ENGLISH CHANNEL TUNNEL

251 French Experience in the Field of Submarine Tunnelling

H. Bejui and T. Avril The authors review French projects in the field of subsea tunnelling, including the English Channel tunnel project and undersea portions of several nuclear power plants.

The Channel Expressway: Twin-Bored Road Tunnels under the English Channel $R$. Comolli et al. An Italian engineering team describes its study for the English Channel fixed link proposal that was offered by Sealink/British Ferries Ltd.

271 The Proposed Design of the English Channel Tunnel

C. J. Kirkland More than 100 years have passed since the idea of a tunnel across the English Channel was first proposed. The technical director of the Channel Tunnel Group, which last year was selected (with France Manche) to build and operate the rail tunnel scheme for the English Channel, provides an overview of the history and development of the project.

UNDERSEA TUNNELLING METHODS

The author evaluates mined, immersed tube, shield-driven and floating tunnel concepts on the basis of conditions favoring or opposing their use. Examples of all of these concepts are presented.

Immersed Tube Tunnelling Offshore: Execution of Immersed Tube Tunnelling Projects under Offshore Conditions, Based on Studies

V. L. Molenaar for the Euroroute Fixed Channel sink Proposal

The author examines two types of building techniques for submarine tunnels: the bored tunnel method and the immersed tube method. Special attention is paid to hydraulic problems and dredging and immersing techniques. 
Inmersed tube technology has been applied in projects in the United States for more than 50 years. The author reviews the history of th 1 type of construction in North America and discussed immersed tube construction methodology and techniques, using examples from the U.S.

Underwater tunnels in the Federal Republic of Germany have employed a number of construction methods, including shield driving, the open cut method, lowering of pneumatic caissons, the use of floating tunnel sections, and the immersed tunnel method. The author illustrates the use of these methods with a variety of examples.

THE KANMON STRAITS TUNNELS

Three undersea rock tunnels pass beneath Japan's Kanmon Straits. This article discusses the two rail tunnels: one for conventional railway lines, and the other for use by high-speed Shinkansen trains. The authors focus on special maintenance requirements for undersea tunnels. Japan's 3.5-km-long Kanmon Highway Tunnel links Honshu mainland and Kyushu Island. Maintenance problems caused by deterioration of the tunnel structures and facilities, and a plan for renovating and maintaining the tunnel are addressed by the author.

THE SEIKAN TUNNEL

The completion in 1985 of the main portion of Japan's Seikan Tunnel represents a major achievement in tunnelling technology. The author traces the 40-year history of the planning, design, construction and operation of this undersea tunnel. Accurate surveying of the geology for the Seikan Tunnel was essential to the selection of appropriate design and construction methods for the tunnel. This article describes the development and results of the surveys performed prior to and during construction of the project.

341 Technical Development for the Seikan Tunnel

Akira Kitamura The length of the Seikan Tunnel and the difficult geological conditions posed by it presented enormous design and construction challenges. The director of the Seikan Undersea Tunnel Bureau describes techniques used to meet some of these challenges. A report by the Geotechnical Committee of the Japan Society of Civil Engineers focuses on the results of the committee's study of theoretical problems related to construction of the Seikan Tunnel. Of special interest is a study of the effects of drainage and the optimum extent of grouting.

The Seikan Tunnel project comprises three tunnels: the main tunnel, a pilot tunnel and a service tunnel. The authors describe the execution of the portions of the undersea section of the tunnel that were performed by contractors, emphasizing excavation methods, grouting, temporary facilities and the system of labor used on the project.

The author discusses the solutions to the problems encountered in the most difficult sections of the Seikan Tunnel: the excavation in squeezing ground; accidents involving inrushing of water; and excavation of unconsolidated zones.

\section{EARTH SHELTER \& ARCHITECTURE}


As a city expands, its urban drainage infrastructure may be taxed to capacity, or beyond it. The authors discuss factors that should be considered in assessing the effectiveness of an urban drainage system.

Meetings
ITA Pages

414 News from Cooperating Organisations

I Volume 1 Contents and Author Index

ISSN 0886-7798 (799) 

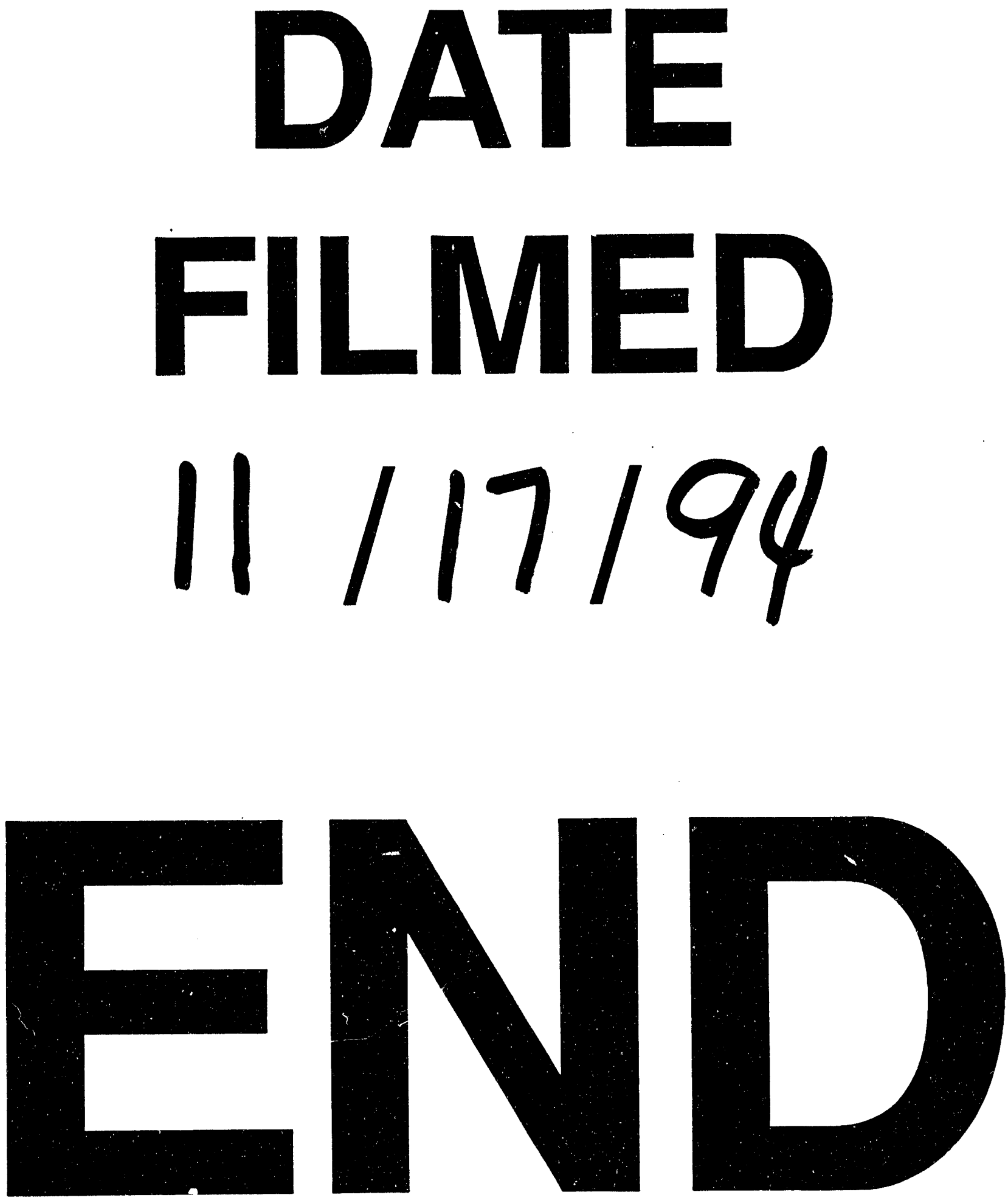
